FERNANDO SANTOS DE SENA

Diversidade de espécies de macroalgas associadas ao Manguezal da Ilha Barnabé, Baixada Santista, SP, Brasil, com base em "DNA Barcode"

São Paulo 2016 
Fernando Santos de Sena

\title{
Diversidade de espécies de macroalgas associadas ao Manguezal da llha Barnabé, Baixada Santista, SP, Brasil, com base em "DNA Barcode"
}

\author{
Versão Revisada
}

Dissertação apresentada ao Instituto de Biociências da Universidade de São Paulo, para a obtenção de Título de Mestre em Ciências, na Área de Botânica.

Orientadora: Prof ${ }^{\underline{a}}$ Dr ${ }^{a}$ Valéria Cassano

São Paulo

2016 
Sena, Fernando Santos de

Diversidade de espécies de macroalgas associadas ao Manguezal da llha Barnabé, Baixada Santista, SP, Brasil, com base em "DNA Barcode"

$113 p$.

Dissertação (Mestrado) - Instituto de Biociências da Universidade de São Paulo. Departamento de Botânica, 2016.

1. Macroalgas, 2. Manguezal. 3. "DNA barcoding". I. Universidade de São Paulo. Instituto de Biociências. Departamento de Botânica

\section{Comissão Julgadora}




\section{Agradecimentos}

À agência financiadora CAPES (Coordenação de Aperfeiçoamento de Pessoal de Nível Superior) pela concessão de bolsa de mestrado.

À Profạ. Dra . Valéria Cassano por ter aberto as portas da pós-graduação, pela valiosa orientação, apoio, constantes ensinamentos e principalmente pela paciência.

Aos professores do LAM, Estela, Flávio, Fungyi, Mariana e Suzana. Foi um imenso prazer conhecê-los.

Ao Rosário Petti, William Silva e André Nakasato pelo suporte técnico. Seria impossível realizar qualquer trabalho sem a ajuda de vocês.

A todos os amigos do LAM pelas conversas, ajudas e pela ótima convivência dentro ou fora do laboratório: Jana, Bia, Cíntia, Fábio, Alexandre, André, Lígia, Fabiana, Carol Azevedo, Karol Magalhães, Gabi, Rafinha, Mari, lagosta, Nuno, Ana, Bruno, Mário, Vanessa, Talissa, Talita, Luzca, Milena

À Cecilia Kano, Khey Fontes e Frederick Leliaert pela valiosa contribuição para a finalização deste trabalho.

À Caroline Ximenes e Rossi pelos trabalhos de bancada.

Ao Prof. Dr. Ricardo Palamar Menghini pelos constantes ensinamentos e pelo auxilio em todas as coletas.

Aos amigos de coleta, Karol Destito, Alê, Kely e Gabi.

Por fim à minha mãe, por todo o apoio, dedicação e paciência. 
"Emmoldurada pelas montanhas longiquas ampliase a região pantanosa em pitoresca irregularidade! $A^{\prime}$ retaguarda a vultuosa Serra do Mar com os alcantis do Morrão sobranceiando as grimpas mais próximas, à frente uma superfície liquida com a largura de vários kilometros e comprimento avaliado em uma légua ou légua e meia, a qual se estende até Santos, à esquerda, atrahido o olhar por uma collina, a ilha Barnabé. Vê-se logo à esquerda uma grande extensão repleta de mangues... A magnifica paisagem que temos deante dos olhos anima-se com as canôas e barcos a vela..."

H. Luederwaldt 


\section{Sumário}

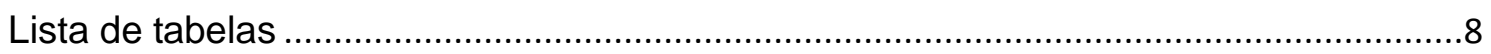

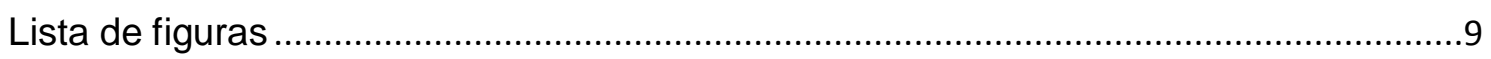

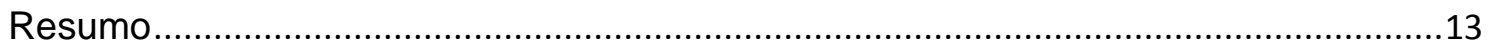

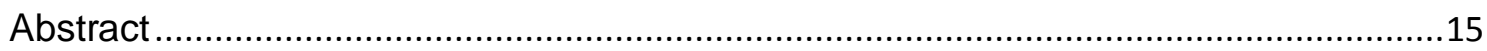

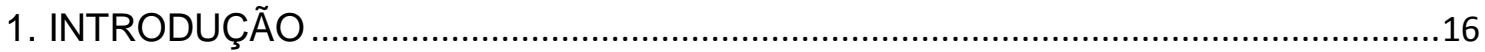

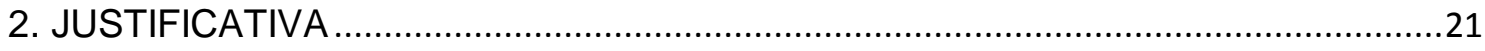

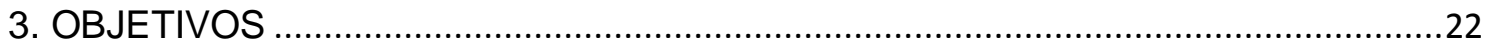

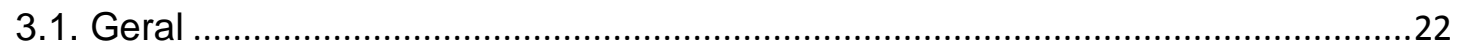

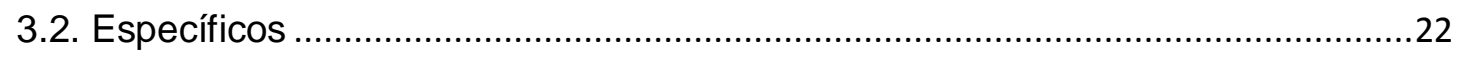

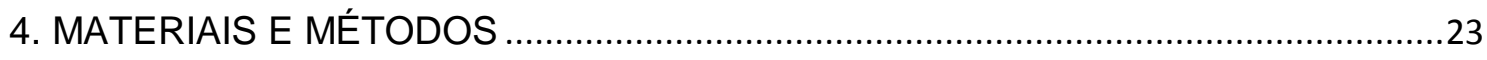

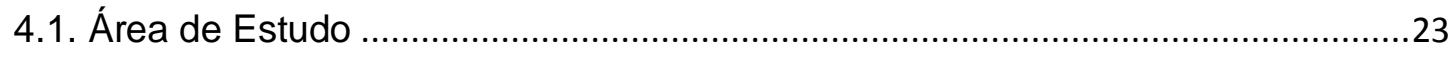

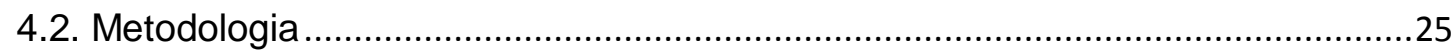

4.2.1. Coletas e armazenamento das amostras .....................................................25

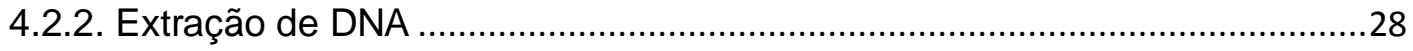

4.2.3. Amplificação dos marcadores moleculares por PCR ("Polymerase Chain

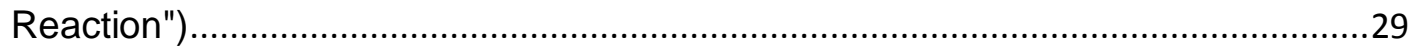

4.2.4. Sequenciamento de DNA e análises filogenéticas ........................................33

4.2.5. Alinhamento e análises moleculares.............................................................33

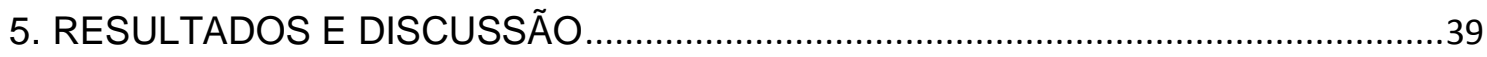

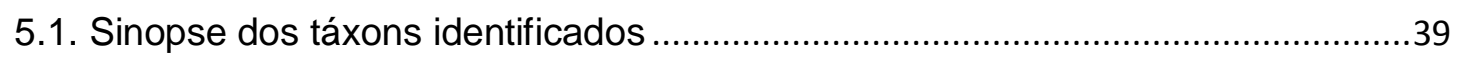

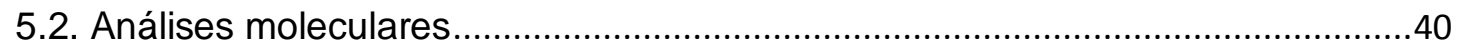

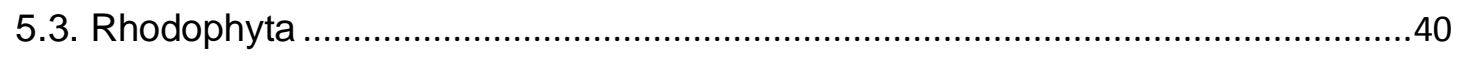

5.3.1. Gênero Bostrychia Montagne e sua parasita Dawsoniocolax bostrychiae (A.B. Joly \& Yamaguishi-Tomita) A.B. Joly \& Yamaguishi-Tomita .........................40

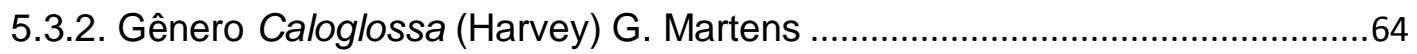




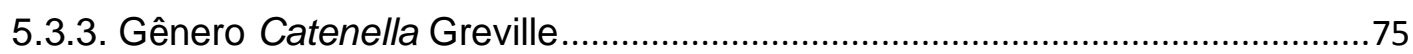

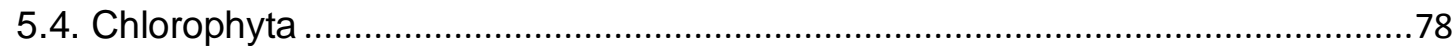

5.4.1. Gênero Boodleopsis Gepp \& E.S. Gepp …..............................................78

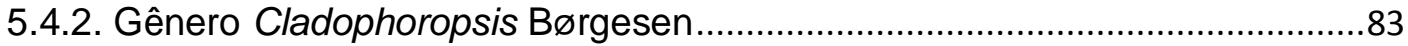

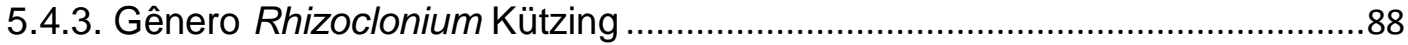

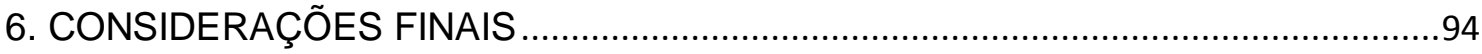

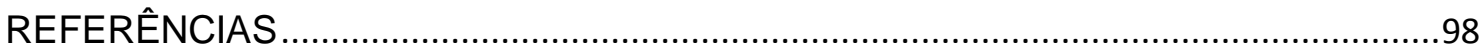

APÊNDICE A - Tabela de amostras sequenciadas ...................................................110 


\section{Lista de tabelas}

Tabela 1 - Lista das coletas realizadas por estação na llha Barnabé, Baixada Santista, SP.....26

Tabela 2 - Relação de "primers" direto $(F)$ e reverso $(R)$ para os diferentes marcadores moleculares utilizados neste estudo. .............................................................31

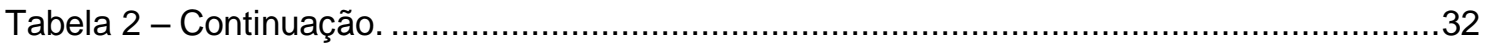

Tabela 3 - Ciclos de PCR utilizados para a amplificação dos marcadores moleculares utilizados. 32

Tabela 4 - Sequências obtidas do GenBank utilizadas nas análises moleculares....................35

Tabela 5 - Ocorrência dos táxons identificados por estações de coleta/amostragem...............94

Tabela 6 - Amostras sequenciadas neste estudo .......................................................110 


\section{Lista de figuras}

Figura 1 - Localização da área de estudo (Baixada Santista). Modificado de Menghini (2008).

Figura 2 - Localização da llha Barnabé na Baixada Santista. Modificado de Menghini (2008). Fonte:Google Earth

Figura 3 - Localização das estações de coleta da llha Barnabé. As bandeiras indicam os transectos. As linhas tracejada e pontilhada indicam a Estrada de ferro e a Rodovia respectivamente. Fonte: Google Earth.

Figura 4 - A-F. Ambientes de coleta da llha Barnabé. A. Vista geral do bosque de mangue da estação 1. B. Detalhe do sedimento. C. Algas aderidas aos rizóforos de $R$. mangle. D. Vista geral do bosque de mangue da estação 3. E-F. Pneumatóforos da estação 2.

Figura 5 - Árvore de Neighbor-Joining (NJ) para as sequências do marcador UPA para o gênero Bostrychia. Apenas valores de bootstrap maiores que 70\% (2000 réplicas) estão representados nos ramos. As sequências obtidas neste estudo estão representadas em negrito na árvore e a sequência retirada do Genbank está seguida do local de coleta e número de acesso.

Figura 6 - Árvore de Neighbor-Joining (NJ) para as sequências do marcador COI-5P para o gênero Bostrychia. Apenas valores de bootstrap maiores que 70\% (2000 réplicas) estão representados nos ramos. As sequências obtidas neste estudo estão representadas em negrito na árvore e a sequência retirada do Genbank está seguida do local de coleta e número de acesso.

Figura 7 - Árvore consenso de (BI) para as sequências de rbcL das espécies de Bostrychia. Nos ramos estão plotados os valores de Bootstrap para as análises de Neighbor-Joining (NJ), Máxima verossimilhança (ML) e Inferência bayesiana (BI). Valores menores que $70 \%$ (ou .70 probabilidade) estão representados como (-). Asterisco $\left(^{*}\right)$ indica suporte total para todas as análises. As sequências obtidas neste estudo estão representadas em negrito na árvore e as sequências retiradas do GenBank estão seguidas do local de coleta e do número de acesso. 
Figura 8 - Representação esquemática do desenvolvimento do haptera em Bostrychia. Seta vermelha indica local de desenvolvimento do haptera. A Periferohaptera. B - Cladohaptera. Modificado de King \& Puttock (1989).52

Figura 9 - Dawsoniocolax bostrychiae. Aspecto geral da parasita (setas) sobre $B$. radicans 2. B- Aspecto geral de uma planta feminina com várias tricogines. C-Detalhe da parasita aderida ao talo de $B$. radicans 2

Figura 10 - "Bostrychia calliptera". A-Aspecto geral do talo. B-Detalhe dos râmulos com estiquídios. C-Detalhe do eixo principal ecorticado. .60

Figura 11 - Bostrychia montagnei. A-Aspecto geral do talo. B-Detalhe do ápice recurvado. C-Detalhe do ramo corticado. D-Detalhe do râmulo de última ordem parcialmente monossifônico.

Figura 12 - Comparação entre espécimes de Bostrychia radicans. A- B. radicans 1. BB. radicans 2 .

Figura 13 - Bostrychia radicans 2. A- Aspecto geral do talo. B-Detalhe do ápice e padrão de ramificação. C- Detalhe ápice polissifônico. D- Detalhe do ramo lateral primário ecorticado. E- Detalhe do talo mostrando ecorticação.

Figura 14 - Bostrychia radicans 2. A- Ápices com estiquídios. B- Ápices com cistocarpos. C- Detalhe de um estiquídio. D- Detalhe de um cistocarpo. ..62

Figura 15 - Bostrychia moritziana 2. A- Aspecto geral do talo. B- Detalhe do padrão de ramificação. C- Detalhe do talo ecorticado e râmulo de última ordem inteiramente monossifônico. D- Detalhe do cladohaptera.

Figura 16 - Árvore de Neighbor-Joining (NJ) para as sequências do marcador UPA para o gênero Caloglossa. Apenas valores de bootstrap maiores que 70\% (2000 réplicas) estão representados nos ramos. As sequências obtidas neste estudo estão representadas em negrito na árvore e a sequência retirada do Genbank está seguida do local de coleta e do número de acesso. .65

Figura 17 - Árvore de Neighbor-Joining (NJ) para as sequências do marcador COI-5P para o gênero Caloglossa. Apenas valores de bootstrap maiores que $70 \%$ (2000 réplicas) estão representados nos ramos. As sequências obtidas neste estudo estão representadas em negrito na árvore e a sequência retirada do Genbank está do número de acesso. .66

Figura 18 - Árvore consenso derivada da análise de Neighbor-Joining (NJ) para as sequências de rbcL das espécies de Caloglossa. Nos ramos estão plotados 
os valores de Bootstrap para as análises de Neighbor-Joining (NJ), Máxima verossimilhança $(\mathrm{ML})$ e Inferência bayesiana $(\mathrm{BI})$. Valores menores que $70 \%$ (ou .70 probabilidade) estão representados como (-). Asterisco $\left(^{*}\right)$ indica suporte total para todas as análises. As sequências obtidas neste estudo estão representadas em negrito na árvore e as sequências retiradas do GenBank estão seguidas do local de coleta e do número de acesso. (Kano et al. 2016, submetido, Apêncide B).

Figura 19 - Caloglossa apomeiotica. A- Aspecto geral do talo. B- Detalhe do padrão de ramificação. C- Detalhe ápice fértil. D- Detalhe dos bisporângios (vista superficial corada com azul de anilina $1 \%$ acidificada com $\mathrm{HCl} 1 \mathrm{~N}$ ). Note tetrasporângio em meio aos bisporângios. .73

Figura 20 - Caloglossa confusa. A- Aspecto geral do talo. B- Detalhe da constrição. CDetalhe da constrição com rizoides. D- Detalhe da fronde mostrado nervura central.

Figura 21 - Caloglossa ogasawaraensis. A- Aspecto geral do talo. B- Detalhe filamento delgado. C- Detalhe da fronde.

Figura 22 - Árvore de Neighbor-Joining (NJ) para as sequências do marcador UPA para o gênero Catenella. O valor de bootstrap (2000 réplicas) está representado no ramo. As sequências obtidas neste estudo estão representadas em negrito na árvore e a retirada do Genbank está seguida do local de coleta e do número de acesso. .75

Figura 23 - Árvore de Neighbor-Joining (NJ) para as sequências do marcador SSU para o gênero Catenella. Apenas valores de bootstrap maiores que 70\% (2000 réplicas) estão representados nos ramos. As sequências obtidas neste estudo estão representadas em negrito na árvore e as retiradas no Genbank estão seguidas do local de coleta e do número de acesso. .76

Figura 24 - Catenella caespitosa. Aspecto geral do talo. Note segmentos ovais e achatados com constriç̧ões bem evidentes e ramificação dicotômica ou tricotômica. .78

Figura 25 - Árvore de Neighbor-Joining (NJ) para as sequências do marcador rbcL para o gênero Boodleopsis. As sequências obtidas neste estudo estão representadas em negrito na árvore e as sequências retiradas do GenBank estão seguidas do local de coleta, quando disponível, e do número de acesso. . .80 
Figura 26 - Boodleopsis pusilla. A- Aspecto geral do talo. B- Detalhe do padrão de ramificação dicotômico. C- Detalhe das constricções nas dicotomias e ao longo do filamento.

Figura 27 - Boodleopsis vaucherioidea. A- Aspecto geral do talo. B- Detalhe da ramificação dicotômica divaricada. C- Detalhe dos râmulos sem constricção nas dicotomias.

Figura 28 - Árvore de Neighbor-Joining (NJ) para as sequências do marcador ITS rDNA nuclear para o gênero Cladophoropsis. Apenas valores de bootstrap maiores que $70 \%$ (2000 réplicas) estão representados nos ramos. As sequências obtidas neste estudo estão representadas em negrito na árvore. As sequências retiradas do GenBank estão seguidas do local de coleta e do número de acesso. 84

Figura 29 - Árvore de Neighbor-Joining (NJ) para as sequências do marcador ITS rDNA nuclear para o gênero Cladophoropsis. Espécimes com morfologia $C$. membranacea estão espalhados em sete clados distintos. As sequências obtidas neste estudo estão representadas em verde na árvore. .85

Figura 30 - Cladophoropsis membranacea. A- Aspecto geral do talo mostrando denso tufo. B- Detalhe ramo lateral novo sem septo na base. C- Detalhe de rizoide. D- Detalhe da célula tentacular. E- Detalhe da ramificação unilateral e rizoide. .88

Figura 31 - Rhizoclonium africanum. A- Detalhe da ramificação secundária. B- Detalhe do septo na ramificação. C- Detalhe rizoide multicelular.

Figura 32 - Rhizoclonium riparium. A- Aspecto geral do talo formando tufos emaranhados. B- Detalhe do filamento unisseriado. C- Detalhe filamento com falsa ramificação. 


\section{Resumo}

Estudos sobre a diversidade de macroalgas de manguezais no Brasil tem-se baseado apenas em abordagens morfológicas, nas quais os caracteres empregados são instáveis e pouco informativos para a identificação e delimitação de espécies. Neste contexto, macroalgas de manguezais foram investigadas pela primeira vez no litoral brasileiro usando uma abordagem molecular, tendo como alvo de estudo o manguezal da Ilha Barnabé, Baixada Santista, São Paulo. Foram utilizados marcadores moleculares do tipo "DNA Barcode", UPA e COI-5P, além do rbcL, amplamente empregado para inferências filogenéticas, e o SSU rDNA. Além desses, os marcadores ITS e tufA foram empregados exclusivamente para as algas verdes, este último sem sucesso. Quinze espécies foram registradas para a área estudada, sendo dez Rhodophyta e cinco Chlorophyta. Destas, duas não novas ocorrências para o Estado de São Paulo, Caloglossa apomeiotica e Boodleopsis vaucherioidea. Das quatro espécies do gênero Bostrychia e sua parasita identificadas neste estudo: "Bostrychia calliptera", B. montagnei, B. moritziana, B. radicans e $D$. bostrychiae, apenas $B$. montagnei revelouse uma espécie molecular e morfologicamente bem definida. As demais formaram complexos de espécies com linhagens moleculares distintas. Para $B$. radicans e $B$. moritziana as análises relevaram três e duas linhagens moleculares, respectivamente, das sete identificadas para o complexo $B$. radicans/ $B$. moritziana na literatura. $O$ táxon identificado como " $B$. calliptera" mostrou alta divergência molecular com sequências de $B$. calliptera do Brasil, apresentando morfologia " $B$. pinnata", um táxon atualmente reduzido a sinônimo de $B$. calliptera. Espécies do gênero Caloglossa, excetuando $C$. ogasawaraensis, são de difícil identificação morfológica devido aos tênues caracteres considerados de valor diagnóstico e a sua considerável plasticidade fenotípica. Caloglossa apomeiotica, $C$. confusa e $C$. leprieurii foram identificadas essencialmente com o emprego de marcadores moleculares. Caloglossa apomeiotica pode ser segregada das demais pela presença de biesporângios, o que impossibilita uma identificação morfológica segura quando coletados talos inférteis, enquanto $C$. confusa possui nós fortemente contritos. Os dados moleculares obtidos para Catenella caespitosa a partir de sequências de SSU sugerem que as citações dessa espécie para o litoral brasileiro podem estar equivocadas já que apresentam alta divergência intraespecífica com $C$. caespitosa do banco de dados. A falta de sequências da localidade tipo, de sequências com marcadores do tipo "DNA Barcode" e de uma maior amostragem molecular das espécies de Catenella nos bancos de dados, nos 
impossibilitaram chegar a um resultado conclusivo. A obtenção de sequências para as algas verdes foi extremamente problemática, inviabilizando uma comparação mais ampla entre as espécies coletadas. Das duas espécies coletadas de Boodleopsis foram obtidas apenas duas sequências parciais de $r b c \mathrm{~L}$ para $B$. vaucherioidea e nenhuma para B. pusilla. A comparação com a única sequência de Boodleopsis depositada nos bancos de dados, uma sequência parcial de $r b c L$ de $B$. pusilla, revelou baixa divergência molecular com as nossas sequências de $B$. vaucherioidea. Além da necessidade de obtenção de sequências completas de rbcL de ambas espécies da área estudada para comparação, uma maior amostragem e o emprego de outros marcadores moleculares são necessários para esclarecer o posicionamento taxonômico desses dois táxons, cuja coespecificidade não pode ser descartada. Morfologicamente, "Cladophoropsis membranacea" é uma espécie facilmente identificada, entretanto sequências de ITS obtidas neste estudo são não comparáveis a nenhuma sequência dessa espécie depositada nos bancos de dados, incluindo sequências da localidade tipo. Reconhecidamente Chadophoropsis é um gênero polifilético e integra o complexo Boodlea que inclui diferentes gêneros de Boodleaceae. A obtenção de sequências de outros marcadores como o SSU rDNA e LSU rDNA assim como uma maior amostragem podem ser informativas para esclarecer a posição das " $C$. membranacea" brasileiras dentro das Cladophorales. Mesmo após inúmeras tentativas não foi possível obter sequências para as duas espécies de Rhizoclonium encontradas, $R$. africanum e $R$. riparium, cuja identificação foi feita com base em caracteres morfológicos tradicionais. 


\section{Abstract}

Studies on the diversity of macroalgae from mangroves in Brazil have been based only on morphological approaches, in which characters used are unstable and uninformative for the species identification and delimitation. In this context, macroalgae of mangroves were investigated for the first time in the Brazilian coast using a molecular approach, having as target of our study the mangrove of the Barnabé Island, Santos, São Paulo. DNA Barcode markers UPA and COI-5P were used, besides the rbcL, largely used for phylogenetic inferences, and also SSU rDNA. In addition to these, the ITS and tufA markers were used exclusively for the green algae, the latter unsuccessfully. Fifteen species were recorded for the studied area, ten Rhodophyta and five Chlorophyta. Of these, two are new records for the State of São Paulo, Caloglossa apomeiotica e Boodleopsis vaucherioidea. Of the four species of the genus Bostrychia identified in this study: "Bostrychia calliptera", B. montagnei, B. moritziana and B. radicans, only $B$. montagnei proved to be a molecular and morphologically well-defined species. The other species formed complexes with different molecular lineages. For $B$. radicans and $B$. moritziana, the analyses showed three and two molecular lineages, respectively, of the seven identified for the $B$. radicans/B. moritziana complex in the literature. The taxon identified as "B. calliptera" showed high molecular divergence with sequences of $B$. calliptera from Brazil, presenting morphology "B. pinnata", a taxon currently reduced to a synonym of $B$. calliptera. Caloglossa species, except $C$. ogasawaraensis, are difficult to identify due to the subtle morphological characters considered of diagnostic value, and their considerable phenotypic plasticity. Caloglossa apomeiotica, $C$. confusa and $C$. leprieurii were identified primarily by the use of molecular markers. Caloglossa apomeiotica can be segregated from the others by the presence of bisporangia, which makes unreliable morphological identification when collected infertile thalli, while $C$. confusa has strongly constricted thallus nodes. The molecular data obtained for Catenella caespitosa from SSU sequences suggest that the citations of this species for the Brazilian coast may be misleading since they have high intraspecific divergence with C. caespitosa from database. Due to the lack of sequences from the type locality, sequences of DNA barcode markers, and a major molecular sampling of Catenella species in databases, became impossible to reach a conclusive result. The obtaining of sequences for green algae was extremely problematic, making impracticable a broader comparison between the collected species. Of the two collected species of Boodleopsis, only two partial sequences of $r b c L$ were obtained for $B$. vaucherioidea and none for $B$. pusilla. The comparison with the unique sequence of Boodleopsis deposited in 
databases, a partial $r b c L$ sequence of $B$. pusilla, revealed low molecular divergence with our sequences of $B$. vaucherioidea. Besides the need to obtain complete sequences of $r b c L$ from both species from the studied area for comparison, an increased sampling and the use of other molecular markers are needed to clarify the taxonomic position of these two taxa, whose conspecificity cannot be disregarded.

Morphologically, "Cladophoropsis membranacea" is an easily identified species, however, ITS sequences obtained in this study are not comparable to any sequence of this species deposited in databases, including sequences from the type locality. Admittedly. Chadophoropsis is a polyphyletic genus and integrates the Boodlea complex that includes different genera of Boodleaceae. The obtaining of sequences from other markers, such as SSU rDNA and LSU rDNA, well as a larger sampling, may be informative to clarify the taxonomic position of "C. membranacea" within the Brazilian Cladophorales. Even after numerous attempts we could not get sequences for the two Rhizoclonium species found in the studied area: $R$. africanum and $R$. riparium, whose identification was made based on traditional morphological characters. 


\section{INTRODUÇÃO}

Os manguezais são ecossistemas costeiros de transição entre o ambiente terrestre e marinho, característicos de regiões tropicais e subtropicais, sujeitos ao regime das marés. Ocorrem em regiões costeiras abrigadas e apresentam condições propícias para alimentação, proteção e reprodução de muitas espécies animais, sendo considerados importantes transformadores de nutrientes em matéria orgânica e geradores de bens e serviços (Schaeffer-Novelli 1995).

O manguezal é considerado como um dos ecossistemas costeiros mais produtivos da biosfera. Esta análise está baseada apenas na produção de serapilheira (Lugo \& Snedaker 1974), porém sabe-se que as algas presentes nos manguezais contribuem diretamente para o aumento da produtividade desse ecossistema. De acordo com os estudos Rodriguez \& Stoner (1990), realizados no estuário de Laguna Joyuda (Porto Rico), os valores de biomassa da flora algácea associadas às raízes de Rhizophora mangle Linnaeus foram similares aos valores anuais de produção de serapilheira.

A comunidade de macroalgas nos manguezais apresenta uma ampla tolerância às condições tipicamente estressantes do ambiente estuarino e uma capacidade de produção líquida mesmo em períodos de emersão, sugerindo desta forma, que estes organismos podem representar uma importante fonte de carbono para os manguezais (Mann \& Steinke 1988, Peña et al. 1999).

Além de atuarem como produtores primários de matéria orgânica, fonte de alimento e substrato para fixação e refúgio de inúmeros animais e microorganismos, as macroalgas apresentam taxas de decomposição bastante elevadas, liberando nutrientes orgânicos e inorgânicos, que podem ser utilizados localmente ou serem exportados para águas adjacentes (Hanisak 1993).

A identificação das espécies de macroalgas que ocorrem em manguezais tem sido baseada quase que exclusivamente em suas características morfológicas vegetativas e reprodutivas. Consequentemente, a morfologia simples e a plasticidade fenotípica encontrada nessas algas dificultam uma delimitação específica adequada. 
Os caracteres vegetativos empregados para delimitar, por exemplo, espécies de Bostrychia Montagne ou Caloglossa (Harvey) G. Martens, comuns em manguezais, tem sido considerados insuficientes para separá-las satisfatoriamente (King et al. 1988, Krayesky et al. 2012, Zuccarello \& West 2006, Zuccarello et al. 2006, 2015, Kamiya \& West 2014). Nesse contexto, marcadores moleculares para analisar a variação de sequências de DNA têm sido amplamente utilizados para identificar e delimitar espécies, bem como inferir relações filogenéticas entre os organismos.

O emprego de marcadores moleculares para desvendar a diversidade de macroalgas de manguezais ainda é incipiente, apenas dois trabalhos foram publicados por Zuccarello et al. (2012) e West et al. (2013). No primeiro deles, os autores estudaram as algas vermelhas dos manguezais de El Salvador e Pacífico mexicano empregando os marcadores LSU rDNA e rbcL para inferir relações filogenéticas dos gêneros Bostrychia Montagne e Caloglossa (Harvey) G. Martens. No segundo trabalho, West et al. (2013) estudaram as macroalgas de manguezais de Guam e da Micronesia, Pacífico ocidental, gerando sequências do espaçador do gene que codifica para a Rubisco e sequências parciais do LSU rDNA, mais uma vez para Bostrychia e Caloglossa.

No Brasil, estudos sobre algas de manguezais foram realizados enfocando principalmente aspectos ecológicos como a distribuição vertical e horizontal (Hadlich 1984, Hadlich \& Bouzon 1985, Miranda \& Pereira 1989, Paula et al. 1989, Eston et al. 1992, Bouzon \& Ouriques 1999, Cunha et al. 1999, Cunha \& Costa 2002, Cunha \& Duarte 2002, Cutrim et al. 2004, Fernandes et al. 2005, Caridade \& Ferreira-Correia 2007, Fernandes \& Alves 2011, Sena 2012, Sena et al. 2012). Um único estudo no Brasil envolvendo ferramentas moleculares foi realizado por Fontes (2012). Entretanto, seu estudo concentrou-se apenas na análise molecular de representantes do gênero Bostrychia por meio de marcadores plastidiais (UPA e $r b c \mathrm{~L}$ ) e mitocondrial (COI-5P).

Com o intuito de minimizar as limitações da taxonomia clássica baseada em caracteres morfológicos, Hebert et al. (2003) analisaram a variação de sequências de DNA de animais utilizando como marcador a região 5' do gene mitocondrial que codifica a subunidade I da enzima citocromo c oxidase (COI-5P ou cox1). Esta técnica 
denominada "DNA Barcoding", em analogia ao sistema de código de barras usado em produtos manufaturados (Stoeckle, 2003), consiste na amplificação por PCR ("Polymerase Chain Reaction") de um segmento de DNA relativamente curto ( 400$700 \mathrm{pb}$ ) que pode ser inteiramente sequenciado com os mesmos dois "primers" usados na PCR. O COI-5P é um "DNA Barcode" padrão amplamente utilizado para vários grupos de animais (Lewis et al. 2011). Como uma ferramenta útil de auxilio à taxonomia tradicional, a eficácia deste método já está estabelecida não apenas em vários grupos de animais, como aves e peixes, mas também em outros grupos de organismos como plantas, fungos e macroalgas.

O sucesso desse marcador como "DNA Barcode" em animais levou Saunders (2005) a propô-lo como um potencial marcador em Rhodophyta. Estudos com diferentes grupos de algas vermelhas marinhas e continentais tem demonstrado que o COI-5P é um marcador eficiente para a discriminação de espécies, incluindo a detecção de espécies crípticas (Clarkston \& Saunders 2010, Costa et al. 2012, Milstein et al. 2012, Paiano \& Necchi 2013, Agostinho \& Necchi 2014, MachínSánchez et al. 2014, Nauer et al. 2014, Saunders \& Millar 2014) Contudo, os primers originais propostos por Saunders (2005) não são eficientes para todos os grupos de algas vermelhas. De fato, um dos maiores problemas na utilização do COI-5P é a falta de primers universais para amplificação, o que tem requerido a utilização de diferentes combinações de primers ou mesmo a utilização de marcadores alternativos (Saunders 2005, Clarkston \& Saunders 2010, Milstein et al. 2012).

O protocolo de extração e a utilidade do COI-5P para algas pardas foram ajustados e testados por McDevit \& Saunders (2009). Entretanto, esse marcador é ineficiente para as algas verdes (Saunders \& Kucera 2010). Devido a essa ineficiência, o marcador plastidial tufA foi proposto como "DNA Barcode" alternativo padrão para esse grupo por Saunders \& Kucera (2010). Esses autores avaliaram vários marcadores do tipo "DNA Barcode" para macroalgas verdes e o tufA demonstrou a mais alta universalidade dentre os marcadores testados, com uma taxa de sucesso de $94 \%$ na sua amplificação, excetuando a família Cladophoraceae, para a qual esse marcador mostrou-se ineficiente, tendo como alternativa o uso do ITS rDNA nuclear, o espaçador intergênico dos genes ribossomais (ITS 1 e ITS 2). O tufA possui cerca de 800 pb e codifica para o fator Tu de elongação, o maior fator que 
possui atividade durante a síntese de proteínas adicionando aminoácidos à cadeia que está sendo construída (Barata 2008). Esse marcador também tem sido usado para inferir relações filogenéticas em gêneros de algas verdes, como Caulerpa J.V. Lamouroux, Halimeda J.V. Lamouroux, Phaeophila Hauck e Ochlochaete Thwaites ex Harvey (Famá et al. 2002, O'Kelly et al. 2004, Barata 2008, Verbruggen et al. 2009 a, b, Zuccarello et al. 2009, Ximenes 2015).

Com a perspectiva de se obter primers universais plastidias, Presting (2006) propôs a utilização do Domínio $V$ do gene que codifica para a subunidade $23 S$ do ribossomo - p23SrV ou UPA (Universal Plastid Amplicon) como um marcador alternativo para organismos fotossintetizantes. O UPA é uma porção de $370 \mathrm{pb}$ e tratando-se de um marcador universal pode ser utilizado para algas verdes, pardas e vermelhas. Estudos posteriores mostraram a marcada universalidade desse marcador na avaliação molecular dos grandes grupos de macroalgas, assim como microalgas marinhas e cianobactérias (Sherwood \& Presting 2007, Sherwood et al. 2008, 2010). Essa região é mais conservada que o COI-5P, entretanto, é mais facilmente amplificada e sequenciada (Saunders \& Kucera 2010). Por outro, lado por ser um marcador muito conservado, tem sido apontadas falhas na delimitação de espécies pelo UPA, e, portanto, o seu uso tem sido indicado com cautela devido à subestimação de espécies (Saunders \& Kucera 2010, Clarkston \& Saunders 2013, Kano 2015).

Sequências do gene plastidial $r b c \mathrm{~L}$, que codifica a subunidade grande da ribulose-1, 5-bisfosfato carboxilase-oxigenase (Rubisco) têm sido amplamente utilizadas para inferir hipóteses filogenéticas e delimitar gêneros e espécies em macroalgas, especialmente após os trabalhos de Freshwater \& Rueness (1994) e Freshwater et al. (1994). O rbcL possui cerca de 1400 pb e não apresenta indels evitando ambiguidades no alinhamento das sequências (Freshwater \& Rueness 1994, Freshwater et al. 1994, 1995, Fredericq et al. 1996). Em algas vermelhas, o rbcL tem sido frequentemente empregado no estudo da diferentes ordens, como Ceramiales (Barros-Barreto et al. 2006, Fujii et al. 2006, Cassano et al. 2012, Fontes 2012), Bangiales (Sutherland et al. 2011, Milstein et al. 2015), Gelidiales (Freshwater et al. 1995, Iha 2014), Gigartinales (Fredericq et al. 1999, Nauer et al. 2014, 2015), Hildenbrantiales (Sherwood \& Sheath 2003) e Gracilariales (Gurgel \& Fredericq 2004, Lyra et al. 2015), gerando hipóteses filogenéticas confiáveis. Para algas verdes, o rbcL 
também tem sido empregado para filogenia de alguns gêneros, como Codium Stackhouse (Oliveira-Carvalho et al. 2012) e Halimeda (Dijoux et al. 2012, Verbruggen et al. 2009b, Ximenes 2015), assim como categorias taxonômicas superiores (Rindi et al. 2007).

O marcador nuclear SSU rDNA (18S), com cerca de $1800 \mathrm{pb}$, que codifica o RNA da subunidade pequena do ribossomo, é conservado apresentando uma taxa lenta de mutação, é de fácil alinhamento e utilizado em níveis taxonômicos diversos e em reconstruções filogenéticas (Oliveira 2001). Por ser mais conservado em suas extremidades o gene pode ser amplificado inteiramente com a utilização de "primers" universais (Oliveira 2001), que pode torná-lo menos laborioso. Neste trabalho, o SSU rDNA foi testado alternativamente para algas verdes devido à ineficiência do COI-5P e tufA e utilizado para algas vermelhas visando a comparação com sequências depositadas nos bancos de dados. Por outro lado, o marcador ITS rDNA nuclear é uma região muito variável sendo recomendada para estudos intra- e interespecíficos (Oliveira 2001) e usado em reconstruções filogenéticas como do gênero Caulerpa J.V. Lamouroux (Stam et al. 2006) e para a ordem Cladophorales (Leliaert et al. 2007a, 2009). De acordo com Alvarez \& Wendel (2003) o ITS rDNA nuclear apresenta potenciais problemas relacionados com a heterogeneidade intra-indivíduo ou dificuldades com múltiplos alinhamentos de sequências devido aos altos níveis de variação, o que foi confirmado por Barata (2008) para o gênero Caulerpa. Apesar disso, o ITS rDNA nuclear pode revelar resultados interessantes ao nível espécífico (Feliner \& Rosello 2007, Barata 2008). A utilidade do ITS rDNA nuclear como marcador do tipo "DNA Barcode" de algas verdes foi avaliada por Saunders \& Kucera (2010), cujos resultados mostraram pelo menos uma baixa taxa de sucesso para as Cladophoraceae, enquanto todos os demais marcadores testado falharam para esse grupo. 


\section{JUSTIFICATIVA}

As macroalgas associadas aos manguezais são organismos de grande importância ecológica sendo fundamentais na manutenção da fauna estuarina. A identificação e delimitação das espécies têm sido baseadas principalmente em caracteres vegetativos e reprodutivos, o que gera dificuldades na sua determinação devido à morfologia simples dessas algas e à sua plasticidade fenotípica. Inventários da flora algácea de manguezal aplicando a técnica de "DNA Barcoding" é inédito no Brasil. Apenas um trabalho é citado para algas de manguezal (Fontes 2012), porém, está restrito ao gênero Bostrychia. Considerando a escassez de dados moleculares de algas de manguezal, estudos como o proposto aqui são necessários para expandir o nosso conhecimento sobre a biodiversidade do manguezal, imprescindível para a conservação e a utilização dos nossos recursos naturais. 


\section{OBJETIVOS}

\subsection{Geral}

- Investigar a diversidade de espécies de macroalgas associadas aos manguezais da llha Barnabé aplicando a técnica de "DNA barcoding".

\subsection{Específicos}

- Sequenciar e comparar os marcadores moleculares do tipo "DNA barcode" (COI-5P, UPA e tufA) e marcadores alternativos (SSU, ITS rDNA nuclear) das amostras coletadas para fins taxonômicos.

- Inferir as relações filogenéticas entre as espécies por meio do gene $r b c L$. 


\section{MATERIAIS E MÉTODOS}

\section{1. Área de Estudo}

A Baixada Santista localiza-se no litoral do Estado de São Paulo (2450' S, $46^{\circ} 45^{\prime}$ W e 2345' S, 4550' W), ocupando posição central na costa. A região metropolitana da Baixada Santista engloba os municípios de Praia Grande, São Vicente, Cubatão, Santos, Guarujá e Bertioga. A área total da Baixada Santista é de $1.329 \mathrm{~km}^{2}$, sendo que $10 \%\left(133 \mathrm{~km}^{2}\right)$ eram ocupados originalmente por manguezais (CETESB, 1991).

Essa região apresenta um clima quente e úmido com temperatura média anual de $22^{\circ} \mathrm{C}$ e precipitação média anual entre 2000 e 2500 mm, não apresentando uma estação seca definida. A umidade relativa do ar é alta, alcançando média anual de 80\% (Santos, 1965; Schaeffer-Novelli \& Cintrón, 1986). Quanto às marés, a região é caracterizada por maré semi-diurnas, com alturas máximas de $1,5 \mathrm{~m}$ acima do nível médio que é de $0,79 \mathrm{~m}$ (DHN, 2012).

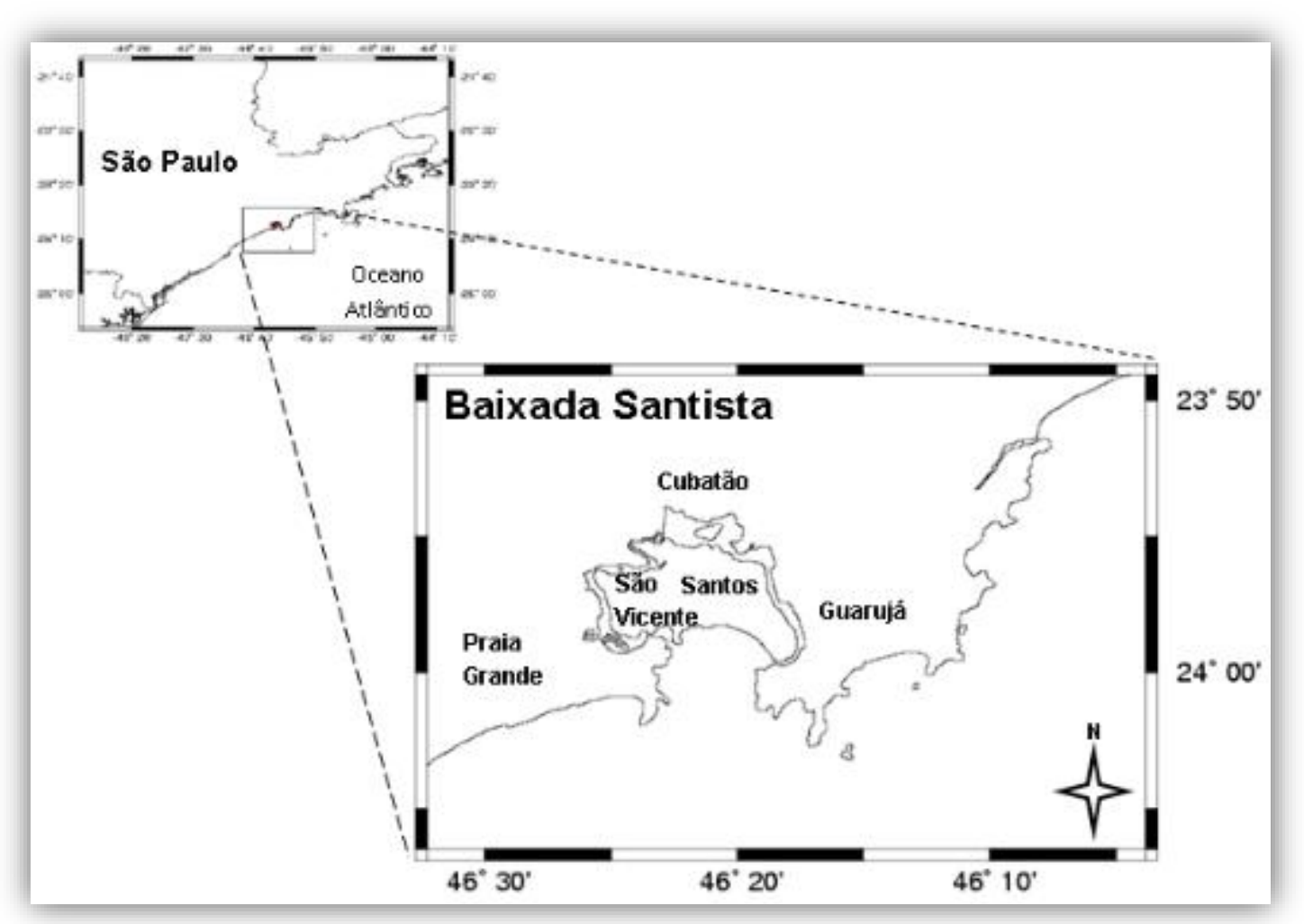

Figura 1 - Localização da área de estudo (Baixada Santista). Modificado de Menghini (2008). 
A Ilha Barnabé localiza-se na parte central do estuário de Santos próximo à desembocadura dos rios Jurubatuba, Sandi e Diana, em frente ao Canal de Santos (Figuras 1 e 2). Apresenta apenas um maciço cristalino na porção sul-sudoeste, onde se iniciou sua ocupação antrópica, o restante de sua área era inteiramente ocupado por manguezais. Porém, na década de 1970 algumas construções como rodovia e estrada de ferro modificaram algumas características locais como alteração do curso do Rio Sandi e aterros, mas ainda se encontram grandes extensões do ecossistema manguezal na llha Barnabé (Menghini 2008).

A caracterização estrutural dos bosques de mangue realizada por Menghini (2008) na área de estudo mostrou que Avicennia schaueriana Stapf \& Leechman ex Moldenke é a espécie dominante logo o sedimento apresenta um extensa cobertura de pneumatóforos com uma comunidade de macroalgas bem desenvolvida.

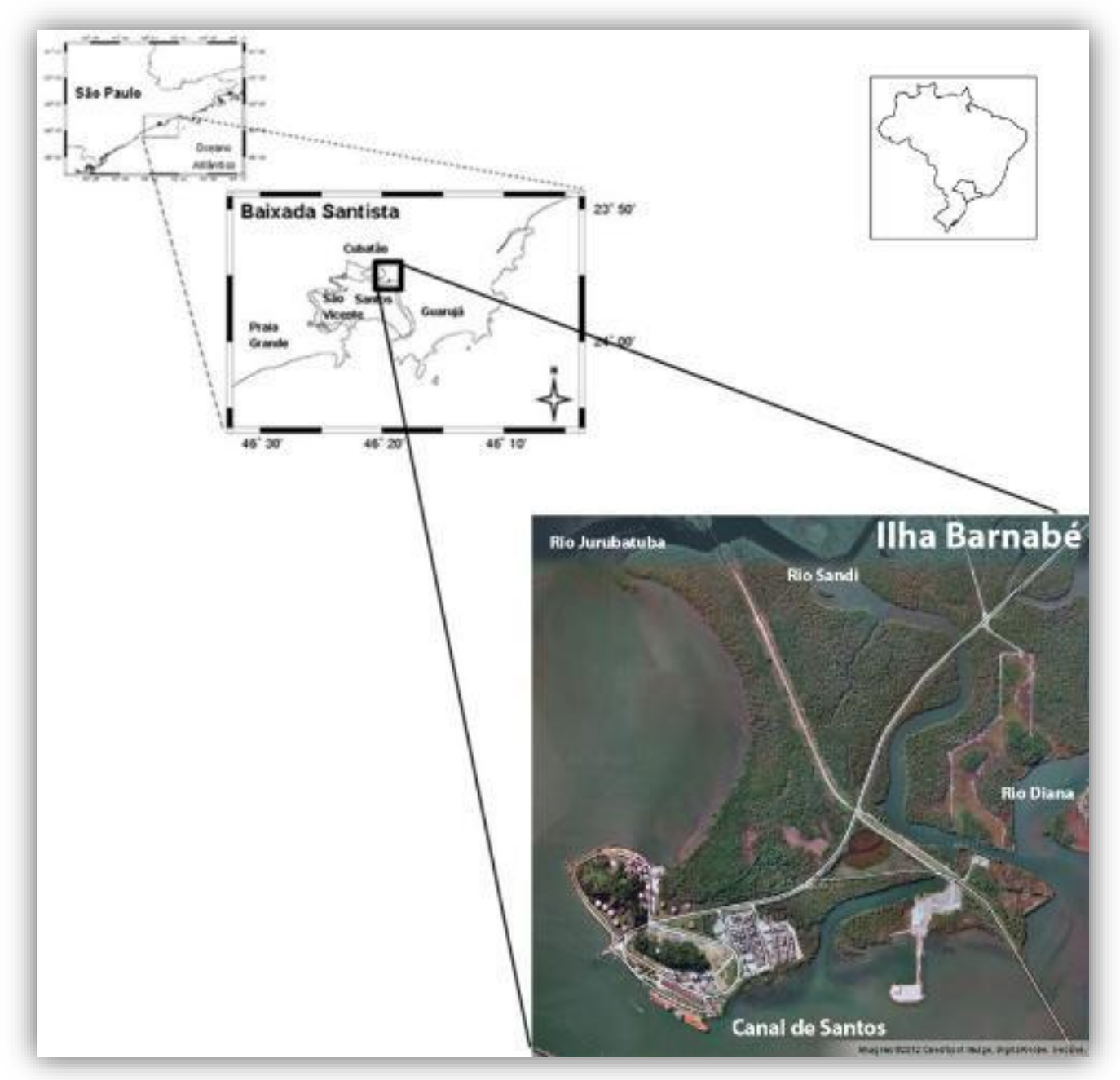

Figura 2 - Localização da Ilha Barnabé na Baixada Santista. Modificado de Menghini (2008). Fonte:Google Earth. 


\subsection{Metodologia}

\subsubsection{Coletas e armazenamento das amostras}

As amostras foram coletadas em 2013-2014 em três estações de coleta eleitas com base nas características locais como facilidade de acesso e disponibilidade de pneumatóforos (Figuras 3 e 4), na zona entre-maré, durante as marés baixas, condição que permite que os pneumatóforos fiquem emersos bem como facilita a movimentação dentro do manguezal (Tabela 1). Na estação 1 (Norte) foram coletados pneumatóforos na franja, paralelamente ao Rio Sandi num transecto de $100 \mathrm{~m}$, e perpendicularmente desde a franja até terra firme num transecto de $150 \mathrm{~m}$. Na estação 2 (Sul), onde resta uma pequena faixa de mangue, a coleta ocorreu paralelamente ao rio num transecto de $100 \mathrm{~m}$. Na estação 3 (Noroeste), devido a impossibilidade de movimentação na franja, os pneumatóforos foram coletados perpendicularmente desde a franja até terra firme num transecto de $100 \mathrm{~m}$.

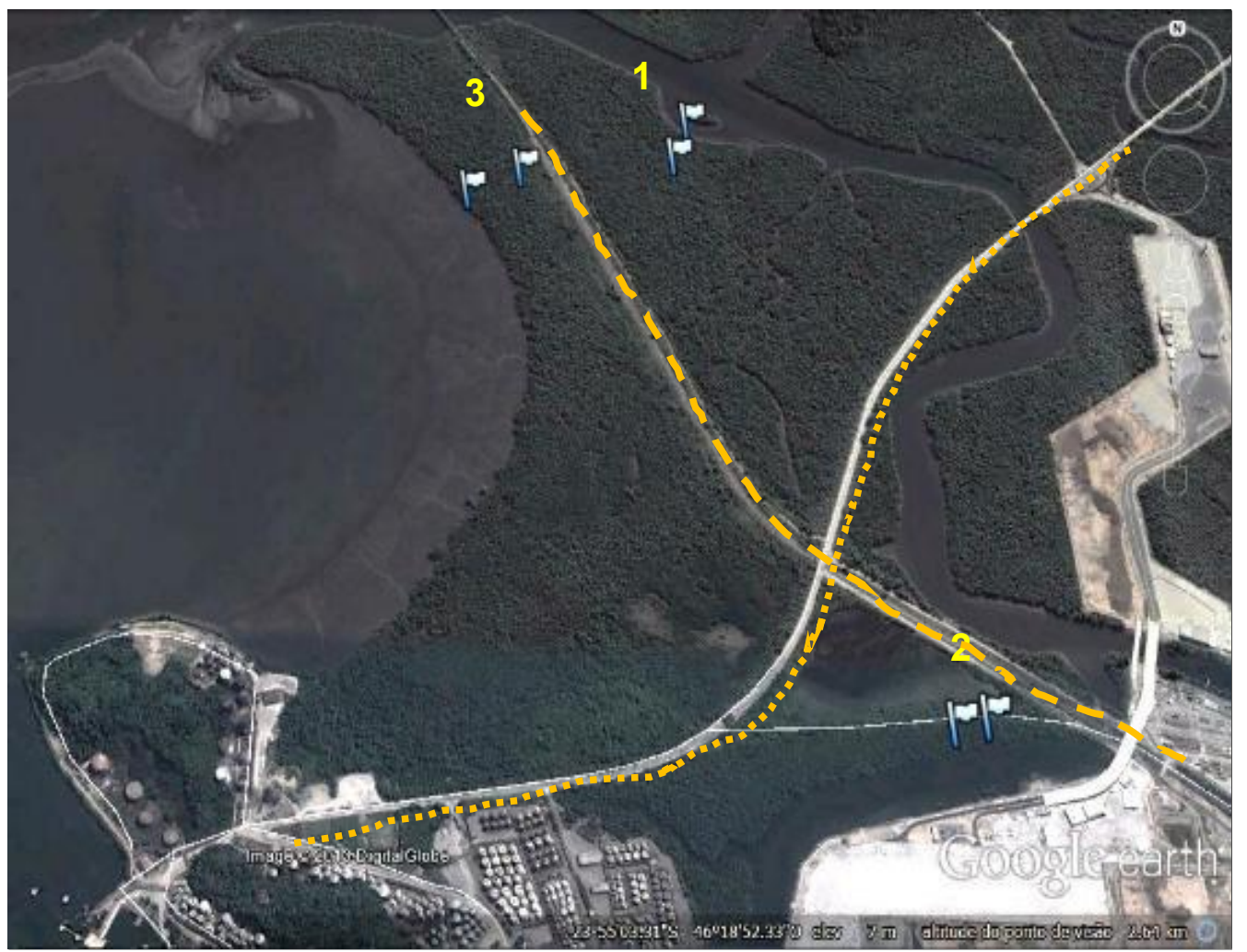

Figura 3 - Localização das estações de coleta da Ilha Barnabé. As bandeiras indicam os transectos. As linhas tracejada e pontilhada indicam a Estrada de ferro e a Rodovia respectivamente. Fonte: Google Earth. 
Tabela 1 - Lista das coletas realizadas por estação na Ilha Barnabé, Baixada Santista, SP.

\begin{tabular}{|c|c|c|c|c|c|}
\hline \multicolumn{2}{|c|}{ Estações } & Data & $\begin{array}{c}\text { Maré }^{*} \\
(\mathrm{~m})\end{array}$ & Coordenadas geográficas & Coletores \\
\hline 1 & Norte & $\begin{array}{l}\text { Fevereiro-2013 } \\
\text { Setembro-2013 }\end{array}$ & $\begin{array}{l}0.2 \\
0.2\end{array}$ & $\begin{array}{l}23^{\circ} 54^{\prime} 28.40^{\prime \prime S}, 46^{\circ} 19^{\prime} 20.20 " \mathrm{e} \mathrm{e} \\
23^{\circ} 54^{\prime} 31.50^{\prime \prime S}, 46^{\circ} 19^{\prime} 21.40^{\prime O} \mathrm{O}\end{array}$ & $\begin{array}{l}\text { F.Sena, R.Menghini, M.Destito, } \\
\text { K.Rocha } \\
\text { F.Sena, R.Menghini, M.Destito }\end{array}$ \\
\hline 2 & Sul & $\begin{array}{l}\text { Setembro-2013 } \\
\text { Fevereiro-2014 }\end{array}$ & $\begin{array}{l}0.2 \\
0.2\end{array}$ & $\begin{array}{l}23^{\circ} 55^{\prime} 9.94^{\prime \prime S}, 46^{\circ} 19^{\prime} 4.00^{\prime \prime O ~ e ~} \\
23^{\circ} 55^{\prime} 10.43^{\prime \prime S}, 46^{\circ} 19^{\prime} 6.19^{\prime \prime O}\end{array}$ & $\begin{array}{l}\text { F.Sena, R.Menghini, M.Destito } \\
\text { F.Sena, R.Menghini, A.Santos }\end{array}$ \\
\hline 3 & Noroeste & Junho-2013 & 0.2 & $\begin{array}{l}23^{\circ} 54^{\prime} 34.83^{\prime \prime S}, 46^{\circ} 19^{\prime} 37.44^{\prime \prime O ~ e ~} \\
23^{\circ} 54^{\prime} 32.92^{\prime \prime S}, 46^{\circ} 19^{\prime} 33.35^{\prime \prime O}\end{array}$ & F.Sena, R.Menghini, S.Macedo \\
\hline
\end{tabular}

*Diretoria de Hidrografia e Navegação da Marinha do Brasil, http://www.mar.mil.br/dhn/chm/box-previsaomare/tabuas/

Os pneumatóforos foram cuidadosamente cortados rente ao sedimento com auxílio de uma tesoura de poda, lavados para retirar o excesso de sedimento e imediatamente acondicionados em garrafas do tipo PET de $500 \mathrm{ml}$ devidamente identificadas. As coletas nos rizóforos de R. mangle e troncos de A. schaueriana foram realizadas com auxílio de espátula e acondicionadas em sacos plásticos do tipo ziplock, já etiquetados. Todas as amostras foram georeferenciadas com uso de aparelho de GPS (Global Positioning System). 

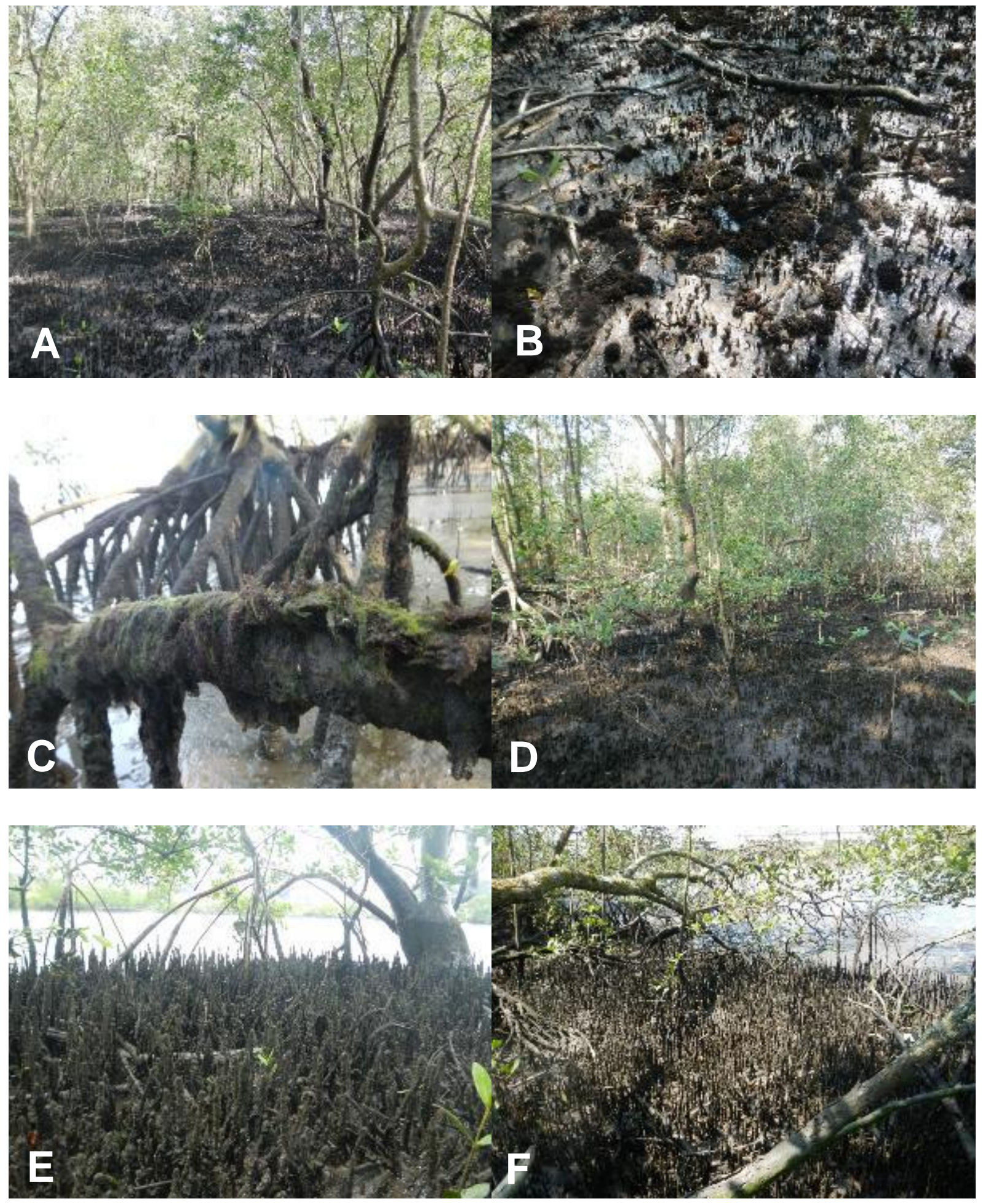

Figura 4 - A-F. Ambientes de coleta da llha Barnabé. A. Vista geral do bosque de mangue da estação 1. B. Detalhe do sedimento. C. Algas aderidas aos rizóforos de R. mangle. D. Vista geral do bosque de mangue da estação 3. E-F. Pneumatóforos da estação 2. 
A triagem foi realizada no Laboratório de Algas Marinhas "Édison José de Paula" - LAM do Departamento de Botânica da Universidade de São Paulo. As algas aderida aos pneumatóforos foi cuidadosamente removidas com o auxílio de esteremicroscópio, marca Leica Wild M3C. Para uma triagem e análise mais detalhada foi utilizado microscópio óptico, marca Nikon Eclipse E-200. Parte do material foi preservada em formol a $4 \%$ em água do mar para análise de caracteres morfológicos e posterior herborização. Medidas de caracteres diagnósticos imprescindíveis para a identificação morfológica das espécies foram feitas por meio de ocular micrométrica, totalizando 15 medidas feitas ao acaso para cada espécime analisado. Ilustrações de cada espécie identificada foram feitas usando-se câmera digital Sony W5. Após análise, os exemplares foram herborizados segundo o método corrente em ficologia (Fidalgo \& Bononi, 1984). As exsicatas foram depositadas no herbário do Instituto de Biociências da Universidade de São Paulo (SPF).

Todos os táxons de algas verdes foram isolados e cultivados com intuito de aumentar sua biomassa. Entre as algas vermelhas, B. moritziana 1 e C. ogasawaraensis foram também cultivadas com o mesmo intuito. $O$ cultivo foi realizado no Laboratório de Algas Marinhas "Édison José de Paula" - LAM do Departamento de Botânica da Universidade de São Paulo. Regiões apicais livre de epífitas foram colocados em frascos Erlenmeyers de $250 \mathrm{ml}$ contendo água do mar esterilizada com $50 \%$ da solução de nutrientes von Stosch (VSES/2) modificado de Ursi \& Plastino (2001), com salinidade de 15 16 UPS e pH: 8,0. Os frascos foram mantidos em câmaras de cultivo com temperatura de $25^{\circ} \mathrm{C} \pm 1$, irradiância de aproximadamente 30 $\mu$ mol fótons. $\mathrm{m}^{-2} \cdot \mathrm{s}^{-1}$ e foto período de $14 \mathrm{~h}$ claro. A troca do meio de cultivo foi feita quinzenalmente.

Para as análises moleculares, regiões apicais livre de epífitas ou indivíduos inteiros, quando diminutos, foram selecionados, secos e envoltos em papel absorvente e preservados em frascos plásticos contendo sílica-gel e mantidos em temperatura ambiente.

\subsubsection{Extração de DNA}

O material previamente mantido em sílica-gel foi macerado em nitrogênio 
líquido em tubos do tipo Eppendorf para quebra da parece celular. Para extração do DNA das algas vermelhas foi utilizado o "kit" de extração NucleoSpin Plant II (Macherey-Nagel, Düren, Alemanha), de acordo com o protocolo do fornecedor. As amostras de algas verdes foram submetidas ao protocolo manual de extração de DNA, CTAB (brometo de cetiltrimetilamônio), Oliveira-Carvalho et al. (2012), constituído pelos seguintes reagentes: água deionizada miliq, CTAB a $2 \%, \mathrm{NaCl}$ a $5 \%, 0,5 \mathrm{M}$ de EDTA, PVP a 1\% e $1 \mathrm{M}$ Tris- $\mathrm{HCl}$ com pH 8.

Após maceração em nitrogênio líquido foi adicionado $700 \mu \mathrm{L}$ do tampão CTAB, juntamente com $7 \mu \mathrm{L}$ de proteinase $\mathrm{K}(20 \mathrm{mg} / \mathrm{mL})$, previamente aquecidos em tubo de Eppendorf $(1,5 \mathrm{~mL})$ em banho seco a $60^{\circ} \mathrm{C}$. O extrato foi incubado a $60^{\circ} \mathrm{C}$ por 30-40 minutos em banho seco. Após este período, adicionou-se à amostra $250 \mu \mathrm{L}$ de acetato de potássio (KOAC) e conservou-se a $-20^{\circ} \mathrm{C}$ por 30 minutos.

A amostra foi centrifugada a $14.000 \mathrm{rpm}$ a $4^{\circ} \mathrm{C}$, por aproximadamente 30 minutos. A fase aquosa da amostra foi transferida para um novo tubo de Eppendorf, adicionando-se um volume de clorofórmio: álcool isomílico (24:1), e posteriormente centrifugada por 10 minutos. Novamente foi transferida a fase aquosa para um novo tubo, adicionando-se um volume de clorofórmio: álcool isomílico (24:1), centrifugando-se por cinco minutos. A fase aquosa da amostra foi transferida para um novo tubo de Eppendorf devidamente etiquetado, onde foi adicionado 0,8 volume de isopropanol $(100 \%)$, incubando-a por um período de 30 minutos à $-20^{\circ} \mathrm{C}$. Após centrifugação, 14.000 rpm por 20 minutos, desprezou-se o sobrenadante e o tubo contendo o DNA foi seco em centrífuga a vácuo durante 30 minutos. O DNA da amostra foi diluído em $50 \mu \mathrm{L}$ de tampão $0,1 \times$ TE (Tris 10mM, pH 8 e EDTA $1 \mathrm{mM}$ ). Todas as amostras de DNA total foram conservadas a $-20^{\circ} \mathrm{C}$.

\subsubsection{Amplificação dos marcadores moleculares por PCR ("Polymerase Chain Reaction")}

Como "DNA barcode" para as algas vermelhas foram utilizados os marcadores COI-5P, região 5' do gene que codifica a subunidade I da enzima citocromo c oxidase, presente no genoma mitocondrial (Saunders 2005), e o Domínio $V$ do gene que codifica para a subunidade $23 S$ do ribossomo - p23SrV ou 
UPA, presente no genoma do cloroplasto (Sherwood \& Presting 2007). Adicionalmente foi utilizado o marcador codificante para a subunidade grande ( $r b c \mathrm{~L}$ ) da enzima ribulose-1,5-bisfosfato carboxilase-oxigenase (Rubisco), também presente no genoma do cloroplasto (Freshwater et al. 1994). Os marcadores COI5P e UPA foram sequenciados para todas as amostras obtidas, enquanto 0 marcador $r b c L$ foi sequenciado para representantes dos agrupamentos formados pelo marcador COI-5P.

Devido à inviabilidade do uso dos marcadores COI-5P e UPA, para as algas verdes foi utilizado o marcador tufA, proposto para "DNA Barcode" de algas verdes por Saunders \& Kucera (2010). O tufA codifica o fator de elongação de proteínas TU, do cloroplasto (cpDNA), que atua durante a síntese de proteínas adicionando aminoácidos na cadeia a ser construída (Famà et al. 2002). Devido à ineficiência desse marcador para as Cladoplorales foram utilizados alternativamente o gene ribossomal nuclear SSU rDNA (18S), que codifica o RNA da subunidade pequena do ribossomo e o gene codificante 5.8S, além dos espaçadores intergênicos dos genes ribossomais ITS1 e ITS2. O gene rbcL (Källersjö et al.,1999) também foi utilizado visando comparar com sequências disponíveis no banco de dados, GenBank.

Os "primers" utilizados na PCR para a amplificação dos marcadores moleculares estão listados na Tabela 2. Para as algas vermelhas, a amplificação do marcador COI-5P foi feita usando-se os "primers" GWSFn e GWSRx, já para a amplificação do marcador UPA foram utilizados os "primers" P23SrVF1 e P23SrVR1. Para o rbcL foram utilizadas as seguintes combinações de "primers": FrbcLS-R753, F492-R1150, F993-RrbcS, gerando três fragmentos sobrepostos. Para as algas verdes, a amplificação do marcador tufA foi feita utilizando-se os "primers" tufAF e tufAR e, em alguns casos, tufGF4 e tufAR. Para o rbcL foram utilizados os "primers" $r b c \mathrm{~L} 1$ e $r b c \mathrm{~L} 2$, enquanto que para o marcador ITS rDNA nuclear foram utilizadas as combinações dos "primers" ITS1FL e Pana4FL e eventualmente ITS1FL e Pana5FL, e para o marcador $18 \mathrm{~S}$ as seguintes combinações: 18S5' -536R, 530F -1055R, 1055F -18S3' gerando assim três fragmentos sobrepostos.

As condições para amplificação foram feitas para um volume final de $50 \mu \mathrm{L}$ : $39,25 \mu \mathrm{L}$ de $\mathrm{H}_{2} \mathrm{O}$ MiliQ autoclavada, $5 \mu \mathrm{L}$ de 10X PCR Buffer do kit Invitrogen (Life Technologies $^{\mathrm{TM}}$, NY, EUA), $1,5 \mu \mathrm{L}$ de $50 \mathrm{mM} \mathrm{MgCl} 2$ do kit Invitrogen, $1 \mu \mathrm{L}$ de dNTP 
$10 \mu \mathrm{M}$ preparada, $1 \mu \mathrm{L}$ de Primer F $10 \mu \mathrm{M}, 1 \mu \mathrm{L}$ de Primer R $10 \mu \mathrm{M}, 0.25$ de Taq DNA Polymerase $(5 \mathrm{U} / \mu \mathrm{L})$ do kit Invitrogen e $1 \mu \mathrm{L}$ de DNA. Em alguns casos outros, métodos de PCR foram utilizados com o PCR Master Mix (Promega, Madison, Wisconsin, USA) e illustra ${ }^{\text {TM }}$ puReTaq Ready-To-Go PCR Beads (GE Healthcare, Buckinghamshire, Inglaterra) ambos seguindo as orientações do fabricante.

Tabela 2 - Relação de "primers" direto (F) e reverso (R) para os diferentes marcadores moleculares utilizados neste estudo.

\begin{tabular}{|c|c|c|c|}
\hline Marcador & Primer & Sequência & Referência \\
\hline COI-5P & GWSFn & 5'-TCA ACA AAY CAY AAA GAT ATY GG-3' & Saunders et al. (2010) \\
\hline COI-5P & GWSRx & 5'-AC TTC TGG RTG ICC RAA RAA YCA-3' & Saunders et al. (2010) \\
\hline UPA & P23SrV F1 & 5'-GGA CAG AAA GAC CCT ATG AA-3' & Sherwood \& Presting (2007) \\
\hline UPA & P23SrV R1 & 5'-TCA GCC TGT TAT CCC TAG AG-3' & Sherwood \& Presting (2007) \\
\hline$r b c L$ & FrbcL Start & 5'-ATG TCT AAC TCT GTA GAA G-3' & Freshwater \& Rueness (1994) \\
\hline$r b c L$ & $\mathrm{R} 753$ & 5'-GCT CTT TCA TAC ATA TCT TCC-3' & Freshwater \& Rueness (1994) \\
\hline$r b c L$ & $\mathrm{R} 492$ & 5'-CGA CAA AAT TTA TCC ATA CG-3' & Freshwater \& Rueness (1994) \\
\hline$r b c L$ & F753 & 5'-GGA AGA TAT GTA TGA AAG AGC-3' & Freshwater \& Rueness (1994) \\
\hline$r b c L$ & F492 & 5'-CGT ATG GAT AAA TTT GGT CG-3' & Freshwater \& Rueness (1994) \\
\hline$r b c L$ & $\mathrm{R} 1150$ & 5'-GCA TTT GTC CGC AGT GAA TAC C-3' & Freshwater \& Rueness (1994) \\
\hline$r b c L$ & F993 & $\begin{array}{l}\text { 5'-GGT ACT GTT GTA GGT AAA TTW GAA GG-3' } \\
(w=a / t)\end{array}$ & Freshwater \& Rueness (1994) \\
\hline$r b c L$ & RrbcS Start & 5'-GTT CTT GTG TTA ATC TCA C-3' & Freshwater \& Rueness (1994) \\
\hline tufA & tufAF & 5'-TGA AAC AGA AMA WCG TCA TTA TGC-3' & Famà et al. (2002) \\
\hline tufA & tufAR & 5'-CCT TCN CGA ATM GCR AAW CGC-3' & Famà et al. (2002) \\
\hline SSU & $18 S 5^{\prime}$ & 5'-CAA CCT GGT TGA TCC TGC CAG T-3' & Sogin (1990) \\
\hline SSU & $536 \mathrm{R}$ & 5'-GAA TTA CCG CGG CTG CTG-3' & Bird et al. (1992) \\
\hline SSU & $530 F$ & 5'-GAG GGC AAG TCT GGT G-3' & Milstein \& Oliveira (2005) \\
\hline SSU & $1055 R$ & 5'-CGG CCA TGC ACC ACC-3' & Bird et al. (1992) \\
\hline SSU & $1055 F$ & 5'-GGT GGT GCA TGG CCG-3' & Bird et al. (1992) \\
\hline SSU & 18S3' & 5'-GAT CCT TCT GCA GGT TCA CCT ACG GAA-3' & Sogin (1990) \\
\hline ITS & ITS1FL & 5'-CCT GCG GAG GGA TCC ATA GC-3' & Leliaert et al. (2009) \\
\hline
\end{tabular}


Tabela 3 - Continuação.

\begin{tabular}{clll}
\hline Marcador & Primer & Sequência & Referência \\
\hline ITS & Pana4FL & 5'-GTTCAGCGGGTGTCCCTG-3' & Leliaert et al. (2009) \\
ITS & Pana5FL & 5'-GGG TGT CCC TGC CTG AAC-3' & Leliaert et al. (2009) \\
$r b c L$ & $r b c L 1$ & 5'--AAA GCN GGK GTW AAA GAY TA-3' & Curtis et al. (2008) \\
$r b c L$ & $r b c L 2$ & 5'-CCA ACG CAT ARA DGG TTG WGA-3' & Curtis et al. (2008) \\
\hline
\end{tabular}

As reações de PCR foram feitas nos termocicladores Techne TC-512 e Techne TC-4000 (Bibby Scientific Ltd, Staffordshire, UK). Os ciclos da PCR utilizados para cada marcador molecular estão listados na Tabela 3.

Tabela 4 - Ciclos de PCR utilizados para a amplificação dos marcadores moleculares utilizados.

\begin{tabular}{|c|c|c|c|c|c|c|c|}
\hline Marcadores & $\begin{array}{c}\text { Desnaturação } \\
\text { Inicial }\end{array}$ & Desnaturação & Anelamento & Extensão & $\begin{array}{c}\text { Extensão } \\
\text { Final }\end{array}$ & Ciclos & Referência \\
\hline COI-5P & $94^{\circ} \mathrm{C}$ por $5^{\prime}$ & $94^{\circ} \mathrm{C}$ por $30^{\prime \prime}$ & $45^{\circ} \mathrm{C}$ por $1^{\prime}$ & $72^{\circ} \mathrm{C}$ por $2^{\prime}$ & $72^{\circ} \mathrm{C}$ por $7^{\prime}$ & $35 x$ & $\begin{array}{l}\text { Saunders } \\
(2005)\end{array}$ \\
\hline UPA & $94^{\circ} \mathrm{C}$ por $2^{\prime}$ & $94^{\circ} \mathrm{C}$ por $20^{\prime \prime}$ & $55^{\circ} \mathrm{C}$ por $30^{\prime \prime}$ & $72^{\circ} \mathrm{C}$ por $30^{\prime \prime}$ & $\begin{array}{c}72^{\circ} \mathrm{C} \text { por } \\
10^{\prime}\end{array}$ & $35 x$ & $\begin{array}{l}\text { Sherwood \& } \\
\text { Presting } \\
(2007)\end{array}$ \\
\hline $\begin{array}{l}\text { rbcL- } \\
\text { vermelhas }\end{array}$ & $94^{\circ} \mathrm{C}$ por $4^{\prime}$ & $94^{\circ} \mathrm{C}$ por $1^{\prime}$ & $40^{\circ} \mathrm{C}$ por $1^{\prime}$ & $\begin{array}{c}72^{\circ} \mathrm{C} \text { por } \\
1^{\prime} 30^{\prime \prime}\end{array}$ & $\begin{array}{c}72^{\circ} \mathrm{C} \text { por } \\
10^{\prime}\end{array}$ & $35 x$ & $\begin{array}{l}\text { Freshwater } \\
\text { et al. (1994) }\end{array}$ \\
\hline tufA & $94^{\circ} \mathrm{C}$ por $3^{\prime}$ & $94^{\circ} \mathrm{C}$ por $1^{\prime}$ & $45^{\circ} \mathrm{C}$ por $1^{\prime}$ & $72^{\circ} \mathrm{C}$ por $2^{\prime \prime}$ & $72^{\circ} \mathrm{C}$ por $4^{\prime}$ & $40 x$ & $\begin{array}{l}\text { Barata } \\
(2008)\end{array}$ \\
\hline SSU & $94^{\circ} \mathrm{C}$ por $4^{\prime}$ & $94^{\circ} \mathrm{C}$ por $30^{\prime \prime}$ & $55^{\circ} \mathrm{C}$ por $30^{\prime \prime}$ & $\begin{array}{c}72^{\circ} \mathrm{C} \text { por } \\
1^{\prime} 30^{\prime \prime}\end{array}$ & $72^{\circ} \mathrm{C}$ por $7^{\prime}$ & $38 x$ & $\begin{array}{l}\text { Saunders \& } \\
\text { Moore } \\
(2013)\end{array}$ \\
\hline ITS & $94^{\circ} \mathrm{C}$ por $3^{\prime}$ & $94^{\circ} \mathrm{C}$ por $1^{\prime}$ & $55^{\circ} \mathrm{C}$ por $1^{\prime}$ & $\begin{array}{c}72^{\circ} \mathrm{C} \text { por } \\
1^{\prime} 30^{\prime \prime}\end{array}$ & $72^{\circ} \mathrm{C}$ por $3^{\prime}$ & $35 x$ & $\begin{array}{l}\text { Leliaert et } \\
\text { al. (2009) }\end{array}$ \\
\hline $\begin{array}{l}\text { rbcL- } \\
\text { verdes }\end{array}$ & $94^{\circ} \mathrm{C}$ por $4^{\prime}$ & $94^{\circ} \mathrm{C}$ por $30^{\prime \prime}$ & $45^{\circ} \mathrm{C}$ por $1^{\prime}$ & $72^{\circ} \mathrm{C}$ por $1^{\prime}$ & $72^{\circ} \mathrm{C}$ por $7^{\prime}$ & $35 x$ & $\begin{array}{l}\text { Curtis et al. } \\
\text { (2008) }\end{array}$ \\
\hline
\end{tabular}

Após a reação os produtos de PCR foram submetidos à eletroforese em gel de agarose $0,7 \%$ e tampão tris-borato-EDTA (TBE: tris-HCl $50 \mathrm{Mm}$, borato 50 $\mathrm{Mm}$, EDTA $2 \mathrm{Mm}$ ) e corados com Gel Loading Buffer (GelRed ${ }^{\mathrm{TM}}$ ) para verificação 
do tamanho do DNA amplificado, comparando-o com o marcador 1Kb DNA Ladder (Invitrogen) através de um transluminador UV, acoplado a um sistema de fotografia digital (Kodak).

Os produtos da PCR foram purificados em colunas GFX'M PCR DNA and Gel Band Purification Kit (GE Healthcare) de acordo com o protocolo do fornecedor. A quantificação do DNA amplificado foi feita por uma estimativa visual, comparando-se a concentração do DNA amplificado e purificado com a concentração de DNA da banda de 1,6Kb do marcador "1Kb DNA ladder" (Invitrogen) seguindo as especificações fornecidas pelo fabricante.

\subsubsection{Sequenciamento de DNA e análises filogenéticas}

O sequenciamento foi feito com aproximadamente 10 a $40 \mathrm{ng}$ de produto de PCR purificado e com o "kit" de sequenciamento "BigDye Terminator Cycle Sequencing Ready Reaction" (Applied Biosystems, Foster City, EUA) utilizando-se os mesmos "primers" da reação de PCR descritos na Tabela 2. As reações de amplificação foram realizadas nas seguintes condições: 40 ciclos a $96^{\circ} \mathrm{C}$ por $10 \mathrm{seg}$, $54^{\circ} \mathrm{C}$ por 20 seg e $60^{\circ} \mathrm{C}$ por 4 min. Após a reação o produto foi precipitados em EDTA $125 \mathrm{mM}$, Acetato de Sódio $3 \mathrm{M}$ e etanol $100 \%$, seguido de lavagem em etanol $70 \%$, segundo recomendação da Applied Biosystems para a remoção de resíduos. O sequenciamento foi realizado nos sequenciadores automáticos $A B I$ PRISM ${ }^{\mathrm{TM}} 3100$ ou ABI PRISM ${ }^{\text {TM }} 3730$ Genetic Analyzer (Applied Biosystems).

\subsubsection{Alinhamento e análises moleculares}

As sequências obtidas foram primeiramente comparadas com as sequências existentes no banco de dados GenBank (http://www.ncbi.nlm.nih.gov/) através do algoritmo BlastN. As sequências direta e reversa foram então manualmente alinhadas através do programa Sequencher ${ }^{\circledR}$ version 4.1.4 sequence analysis software, Gene Codes Corporation (Ann Arbor, MI EUA) (www.genecodes.com), afim de gerar as sequências-consenso. Incongruências nas sequências foram revistas manualmente 
com a análise dos cromatogramas. As sequências-consenso obtidas de todas as amostras foram alinhadas em uma matriz através do programa ClustalX ver. 2.1 (Larkin et al., 2007) e então revistas manualmente usando o programa BioEdit (Hall 1999).

Para os "DNA barcodes", COI-5P e UPA, as matrizes foram construídas apenas com sequências obtidas neste estudo e aquelas gentilmente cedidas pelo Dr. Khey A. Fortes e pela MsC. Cecília H. Kano. Para o marcado rbcL, além das sequências obtidas neste estudo, foram utilizadas 78 do banco de dados GenBank (Tabela 4). Para todos os marcadores foram construídas árvores de agrupamento Neighbor-Joining (NJ) com 2000 réplicas de Bootstrap usando-se o programa PAUP 4.0b8 (Swofford, 2002). Para o marcador $r b c L$ foram utilizados dois métodos de inferência filogenética, além do $\mathrm{NJ}$ : Máxima verossimilhança $(\mathrm{ML})$ e Inferência Bayesiana (BI). O modelo evolutivo utilizado foi determinado pelo programa MrModeltest 2.2 (Nylander, 2004) usando-se o Akaike Information Criterion (AIC). A análise de Máxima verossimilhança $(\mathrm{ML})$ foi feita pelo programa PhyML através do programa TOPALi (Milne et al., 2004) com 100 réplicas de Bootstrap. A Inferência bayesiana $(\mathrm{BI})$ foi feita utilizando-se o programa Mr.Bayes v.3.1.2 (Ronquist \& Huelsenbeck, 2003), com duas corridas com quatro cadeias de Markov, 4.000.000 de gerações com amostragem a cada 100. As gerações iniciais correspondentes ao "burn-in" foram descartadas. Os "gaps" foram considerados dados ausentes e o modelo evolutivo de substituição utilizado foi o modelo $G T R+l+G$, onde assume-se o modelo Geral de Reversão ao longo do Tempo (GTR), com proporção de sítios invariáveis (I) e distribuição $(G)$. As porcentagens de divergência intraespecíficas e interespecíficas foram calculadas usando-se uncorrected ' $p$ ' distances no PAUP.

$\mathrm{Na}$ publicação dos dados, as sequências obtidas nesse estudo serão depositadas nos bancos de dados GenBank (http://www.ncbi.nlm.nih.gov/) e Barcoding of Life Data System (BOLD), (http://www.boldsystems.org; Ratnasinghan \& Hebert 2007). 
Tabela 5 - Sequências obtidas do GenBank utilizadas nas análises moleculares.

\begin{tabular}{|c|c|c|c|}
\hline Espécie & $\begin{array}{l}\text { Número de } \\
\text { acesso }\end{array}$ & Localidade & Referência \\
\hline \\
\hline $\begin{array}{l}\text { Bostrychia Montagne } \\
\text { B. anomala J.A.West, } \\
\text { S.Loiseaux de Goër \& } \\
\text { Zuccarello }\end{array}$ & KC768866 & Kosrae, Micronésia & West et al.(2013) \\
\hline B. arbuscula Harvey & JN881546 & Brighton Beach, Nova Zelândia & Fraser et al. (2013) \\
\hline B. binderi Harvey & KP796015 & Arembepe, Bahia, Brasil & Zuccarello et al.(2015) \\
\hline B. binderi & KP796025 & $\begin{array}{l}\text { Maningrida, Arnhem Land, NT, } \\
\text { Austrália }\end{array}$ & Zuccarello et al.(2015) \\
\hline \multirow{2}{*}{$\begin{array}{l}\text { B. binderi } \\
\text { B. calliptera (Montagne) } \\
\text { Montagne }\end{array}$} & KP796022 & Batam I., Indonésia & Zuccarello et al.(2015) \\
\hline & AY920806 & Sontecomapan, Vera Cruz, México & Zuccarello \& West (2006) \\
\hline B. calliptera & AY920805 & $\begin{array}{l}\text { Rio Sitio Grande, I. do Cardoso, SP, } \\
\text { Brasil }\end{array}$ & Zuccarello \& West (2006) \\
\hline $\begin{array}{l}\text { B. gracilis (R.J.King \& } \\
\text { Puttock) Zuccarello \& J.A. } \\
\text { West }\end{array}$ & JN881544 & Nova Zelândia & Fraser et al. (2013) \\
\hline B. intricata (Bory) Montagne & JN881543 & Nova Zelândia & Fraser et al. (2013) \\
\hline B. kelanensis Grunow & AY920853 & Bowling Green Bay, QLD, Austrália & Zuccarello \& West (2006) \\
\hline B. montagnei Harvey & KP796013 & Playa al Puntilla, El Salvador & Zuccarello et al. (2015) \\
\hline B. montagnei & KP796014 & Isla Mendez, El Salvador & Zuccarello et al. (2015) \\
\hline B. montagnei & KP796019 & Galeta, Panamá & Zuccarello et al. (2015) \\
\hline B. montagnei & KP796026 & $\begin{array}{l}\text { Rio Sitio Grande, I. do Cardoso, SP, } \\
\text { Brasil }\end{array}$ & Zuccarello et al. (2015) \\
\hline B. montagnei & KP796027 & $\begin{array}{l}\text { Rio Sitio Grande, I. do Cardoso, SP, } \\
\text { Brasil }\end{array}$ & Zuccarello et al.(2015) \\
\hline B. montagnei & KP796012 & Playa al Puntilla, El Salvador & Zuccarello et al.(2015) \\
\hline $\begin{array}{l}\text { B. moritziana (Sonder ex } \\
\text { Kützing) J. Agardh }\end{array}$ & AY920811 & Rio Guire, Edo Sucre, Venezuela & Zuccarello \& West (2006) \\
\hline B. moritziana & AY920809 & $\begin{array}{l}\text { Millers Landing, Wilson Promontory, } \\
\text { Victoria, Austrália }\end{array}$ & Zuccarello \& West (2006) \\
\hline B. moritziana & AY920815 & Nusa Dua, Bali, Indonésia & Zuccarello \& West (2006) \\
\hline B. moritziana & AY920816 & Farasan Island, Arábia Saudita & Zuccarello \& West (2006) \\
\hline B. moritziana & AY920813 & West Sawang, Sulawesi, Indonésia & Zuccarello \& West (2006) \\
\hline B. moritziana & KM502788 & Farasan Island, Arábia Saudita & Muangmai et al. (2015) \\
\hline B. moritziana & AY920812 & Buenaventura, Colômbia & Zuccarello \& West (2006) \\
\hline \multirow{2}{*}{$\begin{array}{l}\text { B. pilulifera Montagne } \\
\text { B. radicans (Montagne) } \\
\text { Montagne }\end{array}$} & AY920817 & Demerara River, Guiana & Zuccarello \& West (2006) \\
\hline & AY920824 & Teluk Awang, Lombok, Indonésia & Zuccarello \& West (2006) \\
\hline B. radicans & AY920820 & $\begin{array}{l}\text { Cape Fear Estuary, Carolina do } \\
\text { Norte, EUA }\end{array}$ & Zuccarello \& West (2006) \\
\hline B. radicans & AY920821 & $\begin{array}{l}\text { Estero Coyote, Bahia San Ignacio, } \\
\text { Baja California, México }\end{array}$ & Zuccarello \& West (2006) \\
\hline B. radicans & AY920818 & São Sebastião, São Paulo, Brasil & Zuccarello \& West (2006) \\
\hline $\begin{array}{l}\text { B. simpliciuscula Harvey ex J. } \\
\text { Agardh }\end{array}$ & KM502789 & New South Wales, Forster, Australia & Muangmai et al. (2015) \\
\hline
\end{tabular}


Tabela 4 - Continuação

\begin{tabular}{|c|c|c|c|}
\hline Espécie & $\begin{array}{l}\text { Número de } \\
\text { acesso }\end{array}$ & Localidade & Referência \\
\hline $\begin{array}{l}\text { B. tenella (J.V. Lamouroux) J. } \\
\text { Agardh }\end{array}$ & KP796031 & Dyaul Island, NI, Papua Nova Guine & Zuccarello et al.(2015) \\
\hline B. tenella & KP796021 & $\begin{array}{l}\text { Peniyak Village, Weno I., Chuuk, } \\
\text { Micronésia }\end{array}$ & Zuccarello et al.(2015) \\
\hline B. tenella & KP796018 & Initao, Misamis Oriental, Filipinas & Zuccarello et al.(2015) \\
\hline B. tenella & KM502790 & $\begin{array}{l}\text { Mangrove Trail, Broome, Western } \\
\text { Australia, Australia }\end{array}$ & Muangmai et al. (2015) \\
\hline B. tenella & AY920837 & Ilha de Itaparica, Bahia, Brasil & Zuccarello \& West (2006) \\
\hline $\begin{array}{l}\text { B. vaga J.D.Hooker \& Harvey } \\
\text { Caloglossa (Harvey) } \\
\text { G.Martens }\end{array}$ & JN881538 & Nova Zelândia & Fraser et al. (2013) \\
\hline $\begin{array}{l}\text { C. apomeiotica J.A.West \& } \\
\text { Zuccarello }\end{array}$ & HM775456 & Bahia Balandra, México & Krayesky et al. (2011) \\
\hline C. apomeiotica & HM775457 & El Manchon, Guatemala & Krayesky et al. (2011) \\
\hline C. apomeiotica & HM775459 & Mangaratiba, RJ, Brasil & Krayesky et al. (2011) \\
\hline $\begin{array}{l}\text { C. confusa Krayesky, } \\
\text { J.A.West \& Kamiya }\end{array}$ & JN845517 & Plantation, Flórida, EUA & Krayesky et al. (2012) \\
\hline C. confusa & JN845516 & I. do Cardoso, SP, Brasil & Krayesky et al. (2012) \\
\hline $\begin{array}{l}\text { C. intermedia Kamiya \& } \\
\text { J.A.West }\end{array}$ & HM775468 & James Is., Carolina do Sul, EUA & Krayesky et al. (2011) \\
\hline $\begin{array}{l}\text { C. leprieurii (Montagne) G. } \\
\text { Martens }\end{array}$ & HM775461 & $\begin{array}{l}\text { Isla Magueyes, La Parguera, Porto } \\
\text { Rico }\end{array}$ & Krayesky et al. (2011) \\
\hline C. leprieurii & HM775462 & Cayenne, Guiana Francesa & Krayesky et al. (2011) \\
\hline C. leprieurii & НM775464 & Guiana Inglesa & Krayesky et al. (2011) \\
\hline C. leprieurii & AB862557 & Darwin, Dinah Beach, Austrália & Kamiya \& West (2014) \\
\hline C. leprieurii & HM775463 & Isla Margarita, Venezuela & Krayesky et al. (2011) \\
\hline C. monosticha Kamiya & HM775469 & Derby, Austrália & Krayesky et al. (2011) \\
\hline C. ogasawaraensis Okamura & JN845520 & Carolina do Sul, EUA & Krayesky et al. (2012) \\
\hline C. ogasawaraensis & JN845521 & I. do Cardoso, São Paulo, Brasil & Krayesky et al. (2012) \\
\hline C. ogasawaraensis & AB862546 & Chiba, Sakuta river, Japão & Kamiya \& West (2014) \\
\hline C. ogasawaraensis & AY150325 & Austrália & Kamiya et al. (2004) \\
\hline C. ogasawaraensis & AB862541 & Pueblo Viejo, Guatemala & Kamiya \& West (2014) \\
\hline C. ogasawaraensis & AB862556 & Selangor, Banting, Morib, Malásia & Kamiya \& West (2014) \\
\hline C. ogasawaraensis & AB862552 & Sa, Garden Is. Austrália & Kamiya \& West (2014) \\
\hline C. ogasawaraensis & AB862543 & Ile St. Marie, Madagascar & Kamiya \& West (2014) \\
\hline C. ogasawaraensis & AB862548 & Pohnpei, Sokehs Rock, Micronésia & Kamiya \& West (2014) \\
\hline C. ogasawaraensis & HM775470 & Indonésia & Krayesky et al. (2011) \\
\hline C. rotundata Kamiya & JN845524 & Baía do Panamá, Panamá & Krayesky et al. (2012) \\
\hline C. rotundata & JN845523 & Likin, Guatemala & Krayesky et al. (2012) \\
\hline $\begin{array}{l}\text { C. ruetzleri Krayesky, S. } \\
\text { Fredericq \& J.N. Norris }\end{array}$ & HM775453 & Twin Cays, Belize & Krayesky et al. (2011) \\
\hline \multicolumn{4}{|l|}{ Catenella Greville } \\
\hline $\begin{array}{l}\text { C. caespitosa (Withering) L.M. } \\
\text { Irvine }\end{array}$ & AY437661 & Cultura J. West. 06/05/1993 (G0143) & Saunders et al. (2004) \\
\hline C. nipae Zanardini & AY437662 & Cultura J. West. 18/12/1991 (G0049) & Saunders et al. (2004) \\
\hline
\end{tabular}


Tabela 4 - Continuação

\begin{tabular}{|c|c|c|c|}
\hline Espécie & $\begin{array}{l}\text { Número de } \\
\text { acesso }\end{array}$ & Localidade & Referência \\
\hline \multicolumn{4}{|l|}{$\begin{array}{l}\text { Chlorophyta } \\
\text { Apjohnia Harvey }\end{array}$} \\
\hline $\begin{array}{l}\text { A. laetevirens Harvey } \\
\text { Boodlea G. Murray \& De } \\
\text { Toni }\end{array}$ & AM779624 & Baron Heads, Melbourne, Austrália & Leliaert et al. (2007) \\
\hline $\begin{array}{l}\text { B. composta (Harvey) F.Brand } \\
\text { (como B. siamensis Reinbold) }\end{array}$ & AM779626 & Ilha Mactan, Filipinas & Leliaert et al. (2007) \\
\hline $\begin{array}{l}\text { B. composta (como } B \text {. } \\
\text { siamensis) }\end{array}$ & AF510121 & Chwaka Bay, Zanzibar, Tanzânia & Wysor et al. (não publicado) \\
\hline Boodlea sp. 7 & FN377631 & Chwaka Bay, Zanzibar, Tanzânia & Leliaert et al. (2009) \\
\hline Boodlea sp. 13 & $\begin{array}{l}\text { FN377695, } \\
\text { FN377692 }\end{array}$ & Tumon Bay, Guam & Leliaert et al. (2009) \\
\hline Boodlea sp. 13 & FN377688 & Tumon Bay, Guam & Leliaert et al. (2009) \\
\hline Boodlea sp. 13 & FN377685 & Sawang, Siquijor, Filipinas & Leliaert et al. (2009) \\
\hline \multicolumn{4}{|l|}{$\begin{array}{l}\text { Boodleopsis A.Gepp \& } \\
\text { E.S.Gepp } \\
\text { B. pusilla (Collins) }\end{array}$} \\
\hline $\begin{array}{l}\text { W.R.Taylor, A.B.Joly \& } \\
\text { Bernatowicz }\end{array}$ & DQ469320 & Cockroach Bay, Flórida, EUA & Curtis et al. (2008) \\
\hline \multicolumn{4}{|l|}{ Chamaedoris Montagne } \\
\hline C.auriculata Børgesen & AM779627 & Nogid,Socotra,Yemen & Leliaert et al. (2007) \\
\hline $\begin{array}{l}\text { C. delphinii (Hariot) Feldmann } \\
\text { \& Børgesen }\end{array}$ & AM779635 & $\begin{array}{l}\text { Sodwana Bay, KwaZulu-Natal, África } \\
\text { do Sul }\end{array}$ & Leliaert et al. (2007) \\
\hline $\begin{array}{l}\text { C. peniculum (J.Ellis \& } \\
\text { Solander) Kuntze }\end{array}$ & AM779637 & Puerto Plata, República Dominicana & Leliaert et al. (2007) \\
\hline \multicolumn{4}{|l|}{ Cladophoropsis Børgesen } \\
\hline $\begin{array}{l}\text { C. membranacea (Hofman } \\
\text { Bang ex C.Agardh) Børgesen }\end{array}$ & AF510120 & $\begin{array}{l}\text { Próxima a Isla Grande, Panamá, } \\
\text { Caribe }\end{array}$ & Wysor et al. (não publicado) \\
\hline C. membranacea & AF510113 & $\begin{array}{l}\text { Isla Culebra, Cidade do Panamá, } \\
\text { Panamá (Pacífico) }\end{array}$ & Wysor et al. (não publicado) \\
\hline C. membranacea & AF510114 & $\begin{array}{l}\text { Isla Culebra, Cidade do Panamá, } \\
\text { Panamá (Pacífico) }\end{array}$ & Wysor et al. (não publicado) \\
\hline C. membranacea & AF510117 & Nayarit, Lo de Marcos, México & Wysor et al. (não publicado) \\
\hline C. membranacea & AY055861 & Cane Bay, St. Croix, Ilhas Virgens, & Van Der Strate et al. (2002 \\
\hline C. membranacea & AY055862 & Cane Bay, St. Croix, Ilhas Virgens, & Van Der Strate et al. (2002 \\
\hline C. sundanensis Reinbold & AF510142 & Isla Grande, Panamá (Caribe) & Wysor et al. (não publicado) \\
\hline C. sundanensis & AM779640 & Baía de Mnazi, Tanzania & Leliaert et al. (2007) \\
\hline \multicolumn{4}{|l|}{ Phyllodictyon J.E. Gray } \\
\hline $\begin{array}{l}\text { P. anastomosans (Harvey) } \\
\text { Kraft \& M.J.Wynne }\end{array}$ & AF510136 & $\begin{array}{l}\text { Norte da llha de Wongat, Madang, } \\
\text { Papua New Guinea }\end{array}$ & Wysor et al. (não publicado) \\
\hline $\begin{array}{l}\text { P. anastomosans } \\
\text { Phyllodictyon } \\
\text { gardineri (A.Gepp \& }\end{array}$ & AM779641 & Malta Baths, St Croix, Ilhas Virgens & Leliaert et al. (2007) \\
\hline $\begin{array}{l}\text { E.S.Gepp) Kraft \& M.J.Wynne } \\
\text { (como Struvea gardineri.Gepp } \\
\text { \& E.S.Gepp }\end{array}$ & AM779645 & Plate Island,Seychell & Leliaert et al. (2007) \\
\hline P. pulcherrimum J.E. Gray & AM778983 & $\begin{array}{l}\text { Louisiana, northwest Gulf of Mexico, } \\
\text { EUA }\end{array}$ & Leliaert \& Wysor (não publicado) \\
\hline $\begin{array}{l}\text { P. robustum (Setchell \& N.L. } \\
\text { Gardner) Lelieart \& Wysor } \\
\text { (como Willeeella mexicana } \\
\text { E.Y. Dawson }\end{array}$ & AM778979 & Iguana Island, Panamá & Leliaert et al. (2008) \\
\hline $\begin{array}{l}P \text {. robustum (como } W \text {. } \\
\text { mexicana) }\end{array}$ & AM778978 & $\begin{array}{l}\text { Perlas Islands, Santa Catalina, } \\
\text { Panamá }\end{array}$ & Leliaert et al. (2008) \\
\hline
\end{tabular}


Tabela 4 - Continuação

\begin{tabular}{|c|c|c|c|}
\hline Espécie & $\begin{array}{l}\text { Número de } \\
\text { acesso }\end{array}$ & Localidade & Referência \\
\hline P. robustum & $\begin{array}{l}\text { AM940054, } \\
\text { AM943660 }\end{array}$ & $\begin{array}{l}\text { Puerto Penasco, Baja California, } \\
\text { México }\end{array}$ & Leliaert et al. (2008) \\
\hline $\begin{array}{l}\text { P. orientale (A.Gepp \& } \\
\text { E.S.Gepp) Kraft \& M.J.Wynne }\end{array}$ & AM779643 & Ilha Grande Comoro, Comoros & Leliaert et al. (2007) \\
\hline $\begin{array}{l}\text { Grupos externos } \\
\text { Apoglossum J.Agardh }\end{array}$ & & & \\
\hline $\begin{array}{l}\text { A. ruscifolium (Turner) } \\
\text { J.Agardh }\end{array}$ & KJ960334 & Brittany, Men Vriant, França & Robuchon et al. (não publicado) \\
\hline A. ruscifolium & AF312310 & $\begin{array}{l}\text { Receira da llhas, Ericeira, Lisboa, } \\
\text { Portugal }\end{array}$ & Lin et al. (2001) \\
\hline Caulacanthus Kützing & & & \\
\hline $\begin{array}{l}\text { C. okamurae Yamada } \\
\text { Cladophora Kützing }\end{array}$ & AY437663 & Cultura J. West. 06/05/1993 (G0142) & Saunders et al. (2004) \\
\hline $\begin{array}{l}\text { C. wrightiana Harvey } \\
\text { Halimeda J.V.Lamouroux }\end{array}$ & KF595077 & Gapado, Jeju Island, Corea do Sul & Kim et al. (não publicado) \\
\hline $\begin{array}{l}\text { H. copiosa Goreau \& } \\
\text { E.A.Graham } \\
\text { Heterosiphonia Montagne }\end{array}$ & FJ624508 & Discovery Bay, Jamaica & Verbruggen et al. (2009) \\
\hline $\begin{array}{l}\text { Rhodymeniales sp. } \\
\text { Hypoglossum Kützing }\end{array}$ & HQ421452 & Havaí, EUA & Sherwood et al. (2010) \\
\hline $\begin{array}{l}\text { H. rhizophorum D.L.Ballantine } \\
\text { \& M.J.Wynne }\end{array}$ & HQ421597 & Havaí, EUA & Sherwood et al. (2010) \\
\hline Martensia K.Hering & & & \\
\hline $\begin{array}{l}\text { M. fragilis Harvey } \\
\text { Nitophyllum Greville }\end{array}$ & EF426604 & Havaí, EUA & Sherwood \& Presting (2007) \\
\hline $\begin{array}{l}\text { N. adhaerens M.J.Wynne } \\
\text { Polysiphonia Greville }\end{array}$ & HQ421063 & Havaí, EUA & Sherwood et al. (2010) \\
\hline P. howei Hollenberg & HM573521 & $\begin{array}{l}\text { Flat Rock Beach, Isla Colon, Bocas } \\
\text { del Toro, Panamá }\end{array}$ & $\begin{array}{l}\text { Mamoozadeh \& Freshwater } \\
(2012)\end{array}$ \\
\hline P. howei & HM573543 & $\begin{array}{l}\text { Bocas del Toro, Cayos Tigres, } \\
\text { Panamá }\end{array}$ & Mamoozadeh et al. (2010) \\
\hline
\end{tabular}




\section{RESULTADOS E DISCUSSÃO}

\subsection{Sinopse dos táxons identificados}

\section{Rhodophyta}

Ceramiales

Delesseriaceae

Caloglossa apomeiotica J.A. West \& Zuccarello*

Caloglossa confusa Krayesky, J.A. West \& M. Kamiya

Caloglossa leprieurii (Montagne) G. Martens

Caloglossa ogasawaraensis Okamura

Rhodomelaceae

"Bostrychia calliptera" (Montagne) Montagne

Bostrychia montagnei Harvey

Bostrychia moritziana (Sonder ex Kützing) J.Agardh

Bostrychia radicans (Montagne) Montagne

Dawsoniocolax bostrychiae (A.B.Joly \& Y.-Tomita) A.B.Joly \& Y.-Tomita

Gigartinales

Caulacanthaceae

Catenella caespitosa (Withering) L.M. Irvine

\section{Chlorophyta}

Bryopsidales

Udoteaceae

Boodleopsis pusilla (F.S.Collins) W.R.Taylor, A.B.Joly \& Bernatowicz

Boodleopsis vaucherioidea Calderón-Sáenz \& Schnetter*

Cladophorales

Boodleaceae

"Cladophoropsis membranacea" (Hofman Bang ex C.Agardh) Børgesen

Cladophoraceae

Rhizoclonium africanum Kützing

Rhizoclonium riparium (Roth) Kützing ex Harvey

* Novas ocorrências para o Estado de São Paulo

Espécies grafadas entre aspas não foram confirmadas molecularmente. 


\subsection{Análises moleculares}

Foi coletado um total de 210 amostras para análises moleculares e morfológicas e identificadas 15 espécies para a área estudada, sendo dez rodófitas e cinco clorófitas. Destas, duas são novas ocorrências para o Estado de São Paulo, Caloglossa apomeiotica J.A. West \& Zuccarello e Boodleopsis vaucherioidea Calderón-Sáenz \& Schnetter. A partir das 210 amostras foi obtido um total de 79 sequências (Tabela 6, Apêndice A). Das 160 amostras de algas vermelhas destinadas à biologia molecular foram obtidas 75 sequências, sendo 42 para o marcador UPA, 15 para o marcador COI-5P, 17 para o rbcL e duas para o marcador SSU rDNA. Para 50 amostras de algas verdes coletadas foram obtidas apenas quatro sequências, sendo duas para o marcador ITS rDNA nuclear, duas para o rbcL.

\subsection{Rhodophyta}

\subsubsection{Gênero Bostrychia Montagne e sua parasita Dawsoniocolax bostrychiae (A.B. Joly \& Yamaguishi-Tomita) A.B. Joly \& Yamaguishi-Tomita}

Para a análise molecular com o marcador UPA para os gêneros Bostrychia e sua parasita Dawsoniocolax A.B. Joly \& Yamaguishi-Tomita foi gerada uma matriz com 52 sequências, sendo 32 obtidas neste estudo, 19 por Fontes (2012) e uma sequência de Dasyaceae do GenBank, usada como grupo externo, Heterosiphonia crispella (C. Agardh) M.J. Wynne (HQ421559). O alinhamento final consistiu em 369 pares de base (pb). A árvore de NJ é mostrada na Figura 5. Oito agrupamentos foram resolvidos com valores de suporte altos a moderados, excetuando a parasita Dawsoniocolax bostrychiae (A.B. Joly \& Yamaguishi-Tomita) A.B. Joly \& YamaguishiTomita que se agrupou com duas sequências de Bostrychia tenella (J.V. Lamouroux) J. Agardh de Fontes (2012) com valor de bootstrap de 85\%. A amostra IB99, Bostrychia moritziana 2 obtida neste estudo, manteve-se em um ramo isolado, divergente de 2,7\% (10 pb divergentes) a 2,9\% (11 pb) do agrupamento formado por amostras de B. moritziana 1, obtidas neste estudo e por Fontes (2012), as quais formaram duas linhagens genéticas distintas. 
Heterosiphonia crispella, Havaí (HQ421559)

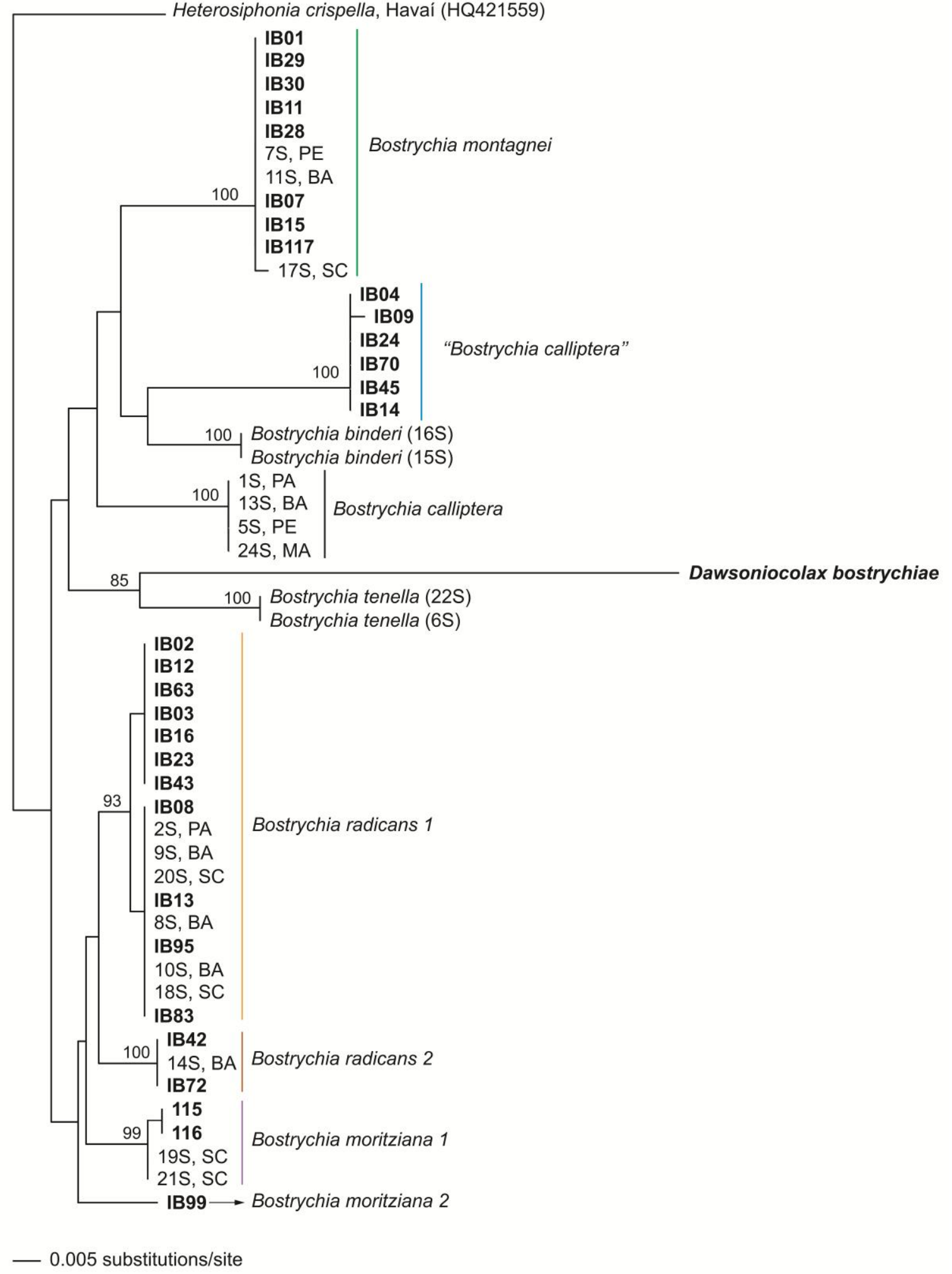

Figura 5 - Árvore de Neighbor-Joining (NJ) para as sequências do marcador UPA para o gênero Bostrychia. Apenas valores de bootstrap maiores que 70\% (2000 réplicas) estão representados nos ramos. As sequências obtidas neste estudo estão representadas em negrito na árvore e a sequência retirada do Genbank está seguida do local de coleta e número de acesso. 
As amostras de $B$. montagnei formaram um único agrupamento com as de Fontes (2012) com alto suporte (100\%) e baixa divergência intraespecífica (0\%$0,27 \%, 1 \mathrm{pb}$ ). Por outro lado, nossas amostras identificadas como " $B$. calliptera" com base na morfologia, não se agruparam com as sequências de $B$. calliptera de Fontes (2012) e formaram dois agrupamentos distintos, ambos com alto suporte (100\%). As amostras denominadas de " $B$. calliptera" apresentaram baixa divergência intraespecífica $(0 \%-0,27 \%)$. A divergência entre "B. calliptera" e B. calliptera (Fontes 2012) foi alta, variando de $6,5 \%$ (24 pb) a $6,7 \%$ (25 pb).

As amostras de Bostrychia radicans formaram duas linhagens genéticas distintas pelo marcador UPA. As amostras denominadas de Bostrychia radicans 1 se dividiram em dois sub-grupos: o primeiro, com sequências $100 \%$ idênticas, formado apenas por amostras obtidas neste estudo, e o segundo também com amostras $100 \%$ idênticas, formado por amostras deste estudo e de Fontes (2012). A divergência entre esses dois subgrupos foi baixa, 0,5\% (2 pb). Por outro lado, as amostras denominadas de $B$. radicans 2 formaram um agrupamento distinto e divergiram de $B$. radicans $1 \mathrm{em}$ $1,9 \%$.

A divergência intraespecífica para as amostras de Bostrychia com o marcador UPA variou de $0,27 \%$ a $1,9 \%$ (7 pb), com a maior divergência encontrada entre as linhagens de $B$. radicans 1 e $B$. radicans 2 , enquanto a divergência interespecífica variou de 2,4\% (9 pb, entre $B$. moritziana 2 e $B$. radicans 2$)$ a $7,3 \%$ (27 pb, entre $B$. moritziana 2 e "B. calliptera"). Portanto, a divergência encontrada entre os agrupamentos B. moritziana 1 e $2(2,7 \%$ a 2,9\%) está na faixa de variação interespecífica observada para este marcador.

A faixa de variação de divergência intraespecífica observada neste estudo para o marcador UPA $(0,27 \%$ a $1,9 \%)$ está de acordo com a divergência encontrada para espécies de Bostrychia por Fontes (2012), 0,3\%. Da mesma forma, a divergência interespecífica observada (2,4\% a 7,3\%), encontra-se na faixa de variação verificada por Fontes (2012) para Bostrychia (2\% a 5,9\%) e por Nauer et al. (2014) para o gênero Hypnea J.V. Lamouroux (2,5\% a 4,4\%).

Como observado pelos nossos resultados, assim como Fontes (2012), não há sobreposição entre os valores de divergência intra- e interespecífica para o marcador UPA, ao contrário do verificado para Halymeniaceae por Yang \& Kim (2014). 
A análise com o UPA claramente mostrou que a parasita Dawsoniocolax bostrychiae se posiciona dentro do gênero Bostrychia, porém a sequência obtida não agrupou com as sequências de seus hospedeiros sobre os quais foi observada, " $B$. calliptera", B. montagnei e B. radicans 2.

Para a análise com o marcador COI-5P foram geradas 13 sequências do gênero Bostrychia e não foi possível obter sequências da parasita $D$. bostrychiae para esse marcador e B. moritziana 1. O COI-5P mostrou-se um marcador de difícil amplificação e alto índice de contaminação e, portanto, com taxa de sucesso muito menor do que o UPA. As dificuldades na amplificação do COI-5P, como amplificação de contaminantes e a necessidade de uso de várias combinações de primers já foram relatadas nos trabalhos de Clarkston \& Saunders (2010) e Milstein et al. (2012).

Para a análise do COI-5P para o gênero Bostrychia foi gerada uma matriz com 29 sequências, 13 deste estudo, oito de Fontes (2012) e oito provenientes do GenBank, sendo Polysiphonia howei Hollenberg (HM573521) usada como grupo externo. A matriz teve um alinhamento final de $663 \mathrm{pb}$. A árvore de NJ é mostrada na Figura 6.

Para as sequências geradas neste estudo foram observados os mesmos agrupamentos genéticos produzidos com o UPA, para a maioria dos táxons, todos com alto suporte (100\%), sendo eles: B. montagnei, "B. calliptera", B. moritziana 2, sendo exceção as amostras de $B$. radicans que foram divididas em três agrupamentos distintos. Para o táxon B. moritziana 1 não foi possível obter sequências de COI-5P. Um outro agrupamento foi formado por quatro espécies, B. arbuscula Harvey, $B$. gracilis (R.J. King \& Puttock) Zuccarello \& J.A. West, B. intricata (Bory) Montagne e B. vaga J.D. Hooker \& Harvey da Nova Zelândia, que parecem ser restritas ao Hemisfério Sul e apresentam morfologia "Stictosiphonia" (King \& Puttock, 1989).

As amostras de B. montagnei foram 100\% idênticas (Fontes 2012, este estudo). Igualmente ao observado com o UPA, os espécimes com morfologia " $B$. calliptera" são 100\% idênticos e não se agruparam com B. calliptera de Fontes (2012), apresentando divergência genética variando de 16,7\% (111 pb) a 17\% (112pb). 


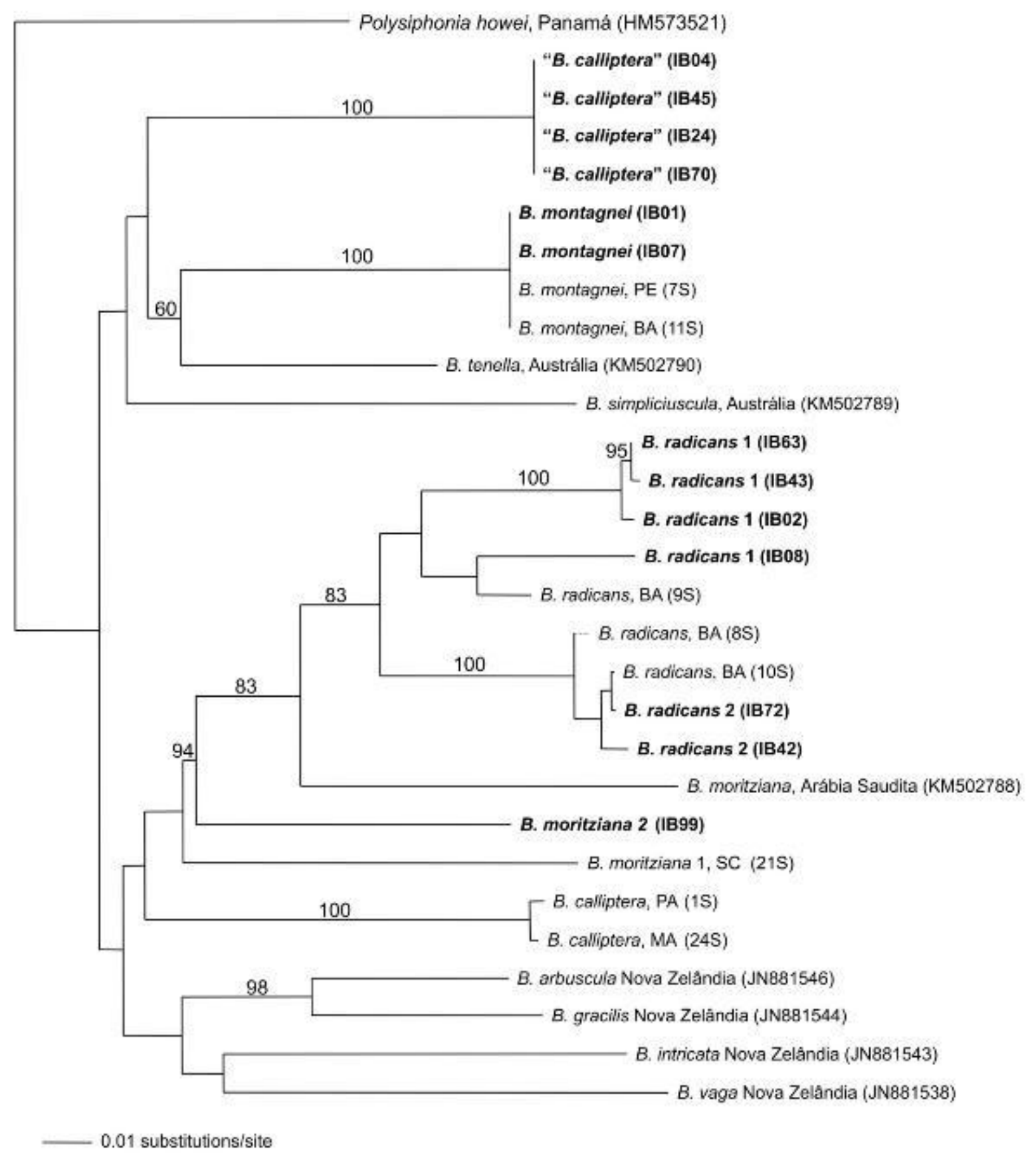

Figura 6 - Árvore de Neighbor-Joining (NJ) para as sequências do marcador COI-5P para o gênero Bostrychia. Apenas valores de bootstrap maiores que $70 \%$ (2000 réplicas) estão representados nos ramos. As sequências obtidas neste estudo estão representadas em negrito na árvore e a sequência retirada do Genbank está seguida do local de coleta e número de acesso.

As amostras de $B$. radicans formaram três sub-grupos monofiléticos com $83 \%$ de valor de bootstrap. As amostras denominadas de $B$. radicans 1 se dividiu em dois agrupamentos, porém sem suporte. As amostras IB02, IB43 e IB63 apresentaram 
baixa divergência intraespecífica $(0,1 \%, 1 \mathrm{pb}-0,4 \%, 3 \mathrm{pb}$.) O outro agrupamento, sem suporte, formado pelas amostras IB08 (este estudo) e 9S (Fontes 2012) apresentou divergência genética de 4,2\% (29 pb). Um terceiro agrupamento com $100 \%$ de suporte foi formado por duas sequências de Fontes (2012) (8S e 10S) que se agruparam com B. radicans 2 deste estudo. Essas amostras de Fontes (2012) se mantiveram no agrupamento de $B$. radicans 1 na análise de UPA. A divergência genética desse terceiro agrupamento variou de $0,1 \%$ (1 pb, entre as amostras IB72 e 10S) a 1,0\% (7 $\mathrm{pb}$, entre as amostras IB42 e 8S).

A divergência genética entre esses três agrupamentos de $B$. radicans variou de 6,9\% (46 pb, entre IB08 e IB63) a 11,9\% (79 pb, entre IB02 e IB42). Comparando com as análises feitas com o UPA percebe-se claramente que três linhagens genéticas foram segregadas a partir do $\mathrm{COI}-5 \mathrm{P}$, enquanto somente duas linhagens foram observadas com o UPA. A amostra $B$. moritziana 2 (IB99) permaneceu em um ramo isolado como uma linhagem independente, assim como pelo UPA, não se agrupando com a sequência de $B$. moritziana de Fontes (2012) nem com a disponível do GenBank.

A divergência intraespecífica de Bostrychia para o COI-5P variou de $0,1 \%$ a $11,9 \%$, considerando as linhagens genéticas de $B$. radicans. Fontes (2012) encontrou uma faixa de variação intraespecífica para $B$. radicans, dentro de uma mesma linhagem, entre $1,6 \%$ a $6,2 \%$. A divergência intraespecífica verificada por Fontes (2012) para outras espécies de Bostrychia não ultrapassou 0,5\%.

A divergência interespecífica entre todas as amostras analisadas variou de $11,9 \%$ entre B. radicans (9S) (Fontes 2012, Brasil) e B. moritziana (Arábia Saudita, KM502788) a 23,4\% (155 pb), entre $B$. vaga (Nova Zelândia, JN881538) e $B$. moritziana (Arábia Saudita). Desta forma, percebe-se a alta divergência observada entre as linhagens brasileiras de $B$. radicans procedentes das regiões sudeste e nordeste do Brasil, que apresentam um limite máximo de divergência intraespecífica $(11,9 \%)$ sobrepondo-se ao limite mínimo de divergência interespecífica $(11,9 \%)$, observado entre amostras dos Oceanos Índico e Pacífico.

A divergência interespecífica para o COI-5P para o gênero Bostrychia (11,9\% a $23,4 \%$ ) mostrou uma maior amplitude de variação quando comparada ao encontrado por Fontes (2012) (12,3\% a 19,8\%). Essas faixas de variação são comparáveis ao observado por Nauer et al. (2014) para o gênero Hypnea (10,1\%-16,3\%), entretanto, 
está bem acima das divergências interespecíficas para o COI-5P descritas por Costa et al. (2012) para Gracilaria (5,8\%-6,5\%) e por Iha et al. 2015 para Gelidium (5,8$6,2 \%)$.

Após as análises de agrupamento geradas pelos marcadores moleculares do tipo "DNA barcode", foram selecionadas amostras representantes de cada agrupamento para o sequenciamento do marcador filogenético rbcL.

Para a análise com o rbcL foram geradas 10 sequências completas mais a região espaçadora ( 1550pb) para o gênero Bostrychia. Não foi possível obter sequências para os táxons " $B$. calliptera", B. moritziana 1 e para a parasita $D$. bostrychiae. Esse marcador foi de difícil amplificação e ocorreu uma elevada incidência de contaminação em amostras de diferentes espécies de Bostrychia, especialmente em " $B$. calliptera”, o que inviabilizou a obtenção de sequências.

Para a análise com o rbcL foi gerada uma matriz com 47 sequências, sendo oito de Fontes (2012) e 29 procedentes do GenBank, além das 10 obtidas neste estudo. A amostra Polysiphonia howei (HM573543) foi usada como grupo externo, gerando um alinhamento final de 1244 pb. A árvore consenso de $\mathrm{Bl}$ é mostrada na Figura 7.

Cinco agrupamentos foram resolvidos com altos valores de suporte, formados pelas espécies, B. binderi Harvey, B. calliptera, B. tenella e B. montagnei, e um agrupamento formado por amostras do complexo B. radicans/B.moritziana de diferentes localidades dos Oceanos Atlântico, Pacífico e Índico. Dois grandes clados foram formados, um deles incluindo representantes com cladohaptera e outro com representantes com peripherohaptera (Fig. 7), diferentes tipos de estruturas de fixação que serão discutidos mais adiante.

As amostras de B. montagnei geradas neste estudo para o marcador $r b c L$ foram $100 \%$ idênticas, igualmente ao observado com o UPA e COI-5P, e agruparamse com amostras do Brasil do GenBank, de El Salvador (Oceano Pacífico) e do Panamá (Galeta, Mar do Caribe, Oceano Atlântico), com 100\% de suporte para todas as análises. Nossas amostras são idênticas à sequência do Caribe, e todas divergiram da sequência do Pacífico em apenas $0,17 \%$ (2 pb). O clado $B$. montagnei apresentou divergência intraespecífica variando de $0 \%$ a 0,8\% (11 pb), cuja maior divergência é referente as amostras brasileiras de Fontes (2012). 
A amostra B. moritziana 2 (IB99) agrupou-se com B. moritziana da Arábia Saudita (AY920816), com 100\% de suporte em todas as análises, e com uma divergência genética de 1,5\% (21 pb). A amostra de $B$. moritziana deste estudo, bem como as de Fontes (2012) e as demais sequências provenientes do GenBank, não se agruparam com a sequência da localidade-tipo, Venezuela (AY920811). A divergência genética entre todas as amostras de $B$. moritziana variou de 0,1\% (1 pb) a 11,7\% (166 $\mathrm{pb})$.

As amostras denominadas de $B$. radicans 1 e $B$. radicans 2 formaram três agrupamentos. As nossas amostras IB42 e IB72 denominadas B. radicans 2 agruparam-se com B. pilulifera Montagne da Guiana (AY920817), e a divergência genética deste grupo variou de 1,3\% (18 pb) a 3,8\% (54 pb). A amostra IB95, que se agrupou com as demais $B$. radicans 1 pelo UPA, permaneceu em um ramo isolado pelo $r b c L$ e divergiu das demais em 1,4\% (19 pb) -1,8\% (25 pb).

As amostras denominadas $B$. radicans 1 (IB08, IB43, IB63, IB83) formaram um agrupamento com uma sequência do Brasil (São Sebastião, São Paulo), proveniente do GenBank (AY920818). A divergência entre as amostras desse agrupamento variou de 0\% a 0,8\%. Duas amostras de B. radicans de Fontes (2012) (S10 e S18) se agruparam com as nossas e com a do GenBank e divergiram de 0,4\% (7 pb) a 3,1\% (44 pb). A divergência genética entre todas as amostras de $B$. radicans variou de $0,4 \%$ a $11,5 \%(163 \mathrm{pb})$.

A divergência interespecífica para Bostrychia encontrada por Fontes (2012) para o rbcL $(9,1 \%$ a $22,5 \%)$ mostrou uma amplitude de variação maior do que 0 observado nos nossos resultados. Para outros gêneros de algas vermelhas foram observadas amplitudes de variação menores, como, por exemplo, para Hypnea (3.2\%$6.8 \%$, Nauer et al. 2014, 2015) e Gelidiella $(5,4 \%-7,5 \%$, Iha 2014),

A divergência interespecífica entre todas as amostras analisadas variou de 7,3\% (104 pb) entre B. radicans 2 do Brasil (IB42) e B. moritziana da Indonésia (AY920815) a 15,6\% (222 pb) entre B. tenella do Brasil (AY920837) e B. radicans do Brasil (S10) (Fontes 2012). Desta forma, percebe-se a alta divergência genética do complexo B. radicans/B.moritziana cuja amplitude de variação para as duas espécies se sobrepõe à divergência interespecífica observada para outras espécies de Bostrychia. 


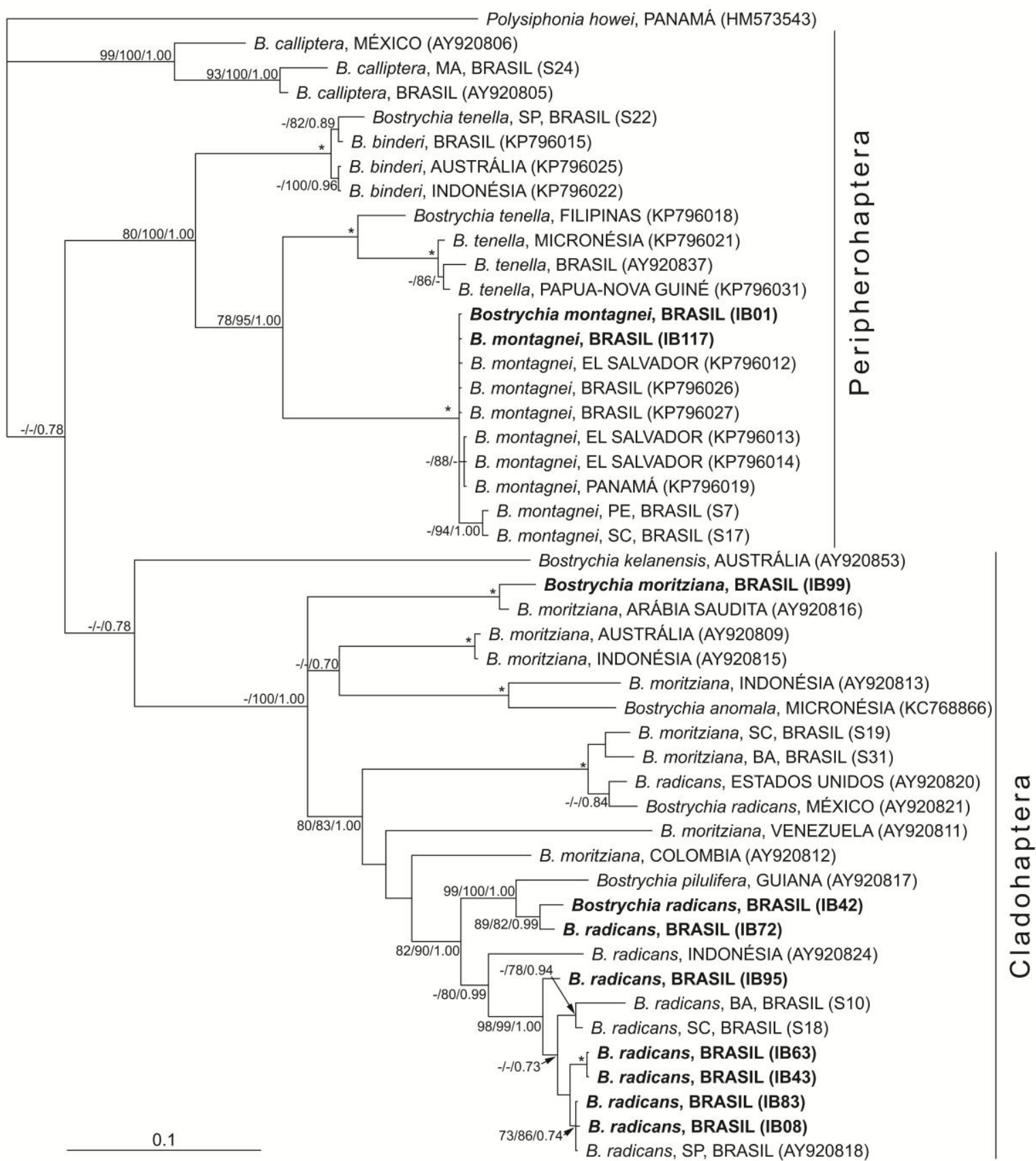

Figura 7 - Árvore consenso de (BI) para as sequências de rbcL das espécies de Bostrychia. Nos ramos estão plotados os valores de Bootstrap para as análises de Neighbor-Joining (NJ), Máxima verossimilhança (ML) e Inferência bayesiana (BI). Valores menores que 70\% (ou .70 probabilidade) estão representados como (-). Asterisco $(*)$ indica suporte total para todas as análises. As sequências obtidas neste estudo estão representadas em negrito na árvore e as sequências retiradas do GenBank estão seguidas do local de coleta e do número de acesso.

O gênero parasita Dawsoniocolax foi descrito por Joly \& Yamaguishi-Tomita (1967) como Dawsoniella A.B. Joly \& Yamaguishi-Tomita, nome ilegítimo (non Dawsoniella Hollenberg 1967). Mais tarde, visando corrigir essa homonímia, os 
autores estabeleceram o gênero monoespecífico Dawsoniocolax. A única espécie descrita até hoje para o gênero, D. bostrychiae, cuja localidade tipo é São Paulo, Brasil, foi originalmente descrita como uma aloparasita de $B$. radicans, $B$. montagnei e $B$. calliptera, uma vez que a espécie foi alocada primeiramente na família inteiramente parasita, Choreocolacaceae, Gigartinales. Guimarães (1993), que estudou o desenvolvimento vegetativo e reprodutivo desta espécie a partir de material coletado no Espírito Santo e São Paulo, encontrou $D$. bostrychiae parasitando $B$. moritziana, além de $B$. radicans, nos manguezais dos rios Piraquê-Açu (ES) e Sítio Grande, Iha do Cardoso (SP). Fora o Brasil, a espécie é citada apenas para a Austrália, crescendo sobre B. radicans (West \& Calumpong, 1988, King \& Puttock 1989).

A especificidade da parasita com seus hospedeiros foi avaliada por Zuccarello \& West (1994) a partir de material coletado na llha do Cardoso. Nos experimentos de cultura desenvolvidos, $D$. bostrychiae foi capaz de crescer apenas em $B$. radicans. Como, de acordo com Guimarães (1993), espécimes de $D$. bostrychiae não foram mais encontrados sobre $B$. montagnei e $B$. calliptera até aquela data e, em cultura, a parasita não foi capaz de crescer sobre essas duas espécies, Zuccarello \& West (1994) levantaram a hipótese de que a obra original foi baseada em erros de identificação dos hospedeiros. Entretanto, nossos resultados indubitavelmente refutam essa hipótese, uma vez que a parasita foi encontrada também crescendo sobre "B. calliptera".

Zuccarello et al. (2004) realizaram análises filogenéticas de parasitas da família Choreocolacaceae, com base no gene nuclear SSU rRNA para os gêneros, Holmsella Sturch (parasita de Gracilaria Greville e Gracilariopsis E.Y. Dawson); Harveyella mirabilis (Reinsch) F. Schmitz \& Reinke e a hiperparasita Gonimophyllum skottsbergii Setchell (parasitas de Polysiphonia Greville e Odonthalia Lyngbye); Choreocolax polysiphoniae Reinsch e Leachiella pacifica Kugrens (parasitas de Polysiphonia) e Bostrychiocolax australis Zuccarello \& West e Dawsoniocolax bostrychiae (parasitas de Bostrychia). Os resultados obtidos por Zuccarello et al. (2004) demonstraram que todas as parasitas estudadas se agruparam nas famílias de seus respectivos hospedeiros e, portanto, $D$. bostrychiae foi alocada na tribo Bostrychiae, Rhodomelaceae. Assim, Choreocolacaceae não é mais uma família reconhecida taxonomicamente desde Zuccarello et al. (2004). 
Outras espécies parasitas da família Rhodomelaceae também tem sido investigadas sob uma abordagem molecular. Kurihata et al. (2010) usando sequências parciais dos genes nucleares SSU e LSU rRNA e o marcador COI-5P verificaram que a parasita de Laurencia J.V. Lamouroux, Janczewskia hawaiiana K.E. Apt se manteve dentro de tribo Laurencieae, posicionada em Laurencia sensu stricto em todas as análises, mas não estreitamente relacionada com seu hospedeiro, L. mcdermidiae I.A. Abbott; enquanto que os gêneros Benzaitenia Yendo e Ululania K.E. Apt \& K.E. Schlech, parasitas de Chondria Link, se posicionaram dentro da tribo Chondrieae.

De acordo com Zuccarello et al. (2004), aproximadamente $80 \%$ das parasitas de algas vermelhas são estreitamente relacionadas com seus hospedeiros, estando taxonomicamente dentro da mesma tribo ou família, com base em características morfológicas e/ou reprodutivas, sendo denominados de adelfoparasitas (Goff 1982). Os dados moleculares tem corroborado essa afirmação, cujas parasitas se agrupam nos mesmos clados que seus gêneros hospedeiros, como verificado para as parasitas de Laurencia e Chondria (Kurihata et al. 2010) e para D. bostrychiae posicionada dentro do gênero Bostrychia (Zuccarello et al. 2004, este estudo).

As relações filogenéticas entre as parasitas e seus hospedeiros, e caracteres morfo-anatômicas compartilhados entre eles (Fujii \& Guimarães 1999, Le Gall \& Saunders 2010, Zuccarello et al. 2004, Kurihata et al. 2010) indicam ser razoável a transferência nomenclatural de espécies de parasitas para seus gêneros hospedeiros, como feito por Le Gall \& Saunders (2010) com a espécie parasita Ceratocolax hartzii Rosenvinge transferida para seu gênero hospedeiro Coccotylus (Coccotylus hartzii (Rosenvinge) L. Le Gall \& G.W. Saunders), cujas sequências de COI-5P foram curiosamente idênticas. Uma posição mais conservadora tem sido adotada para as demais espécies parasitas mencionadas acima, que apesar de seu posicionamento filogenético, têm sido mantidas em gêneros independentes de seus respectivos hospedeiros.

Análises moleculares mais aprofundadas com obtenção de sequências de $D$. bostrychiae para outros marcadores são necessárias para esclarecer seu posicionamento filogenético.

Aspectos de $D$. bostrychiae são mostrados na Figura 9A-C. Detalhes morfológicos vegetativos e reprodutivos de $D$. bostrychiae são fornecidos por Guimarães (1993). 
O gênero cosmopolita, Bostrychia é um dos mais bem conhecidos gêneros de algas vermelhas associado a manguezais de todo o mundo (King \& Puttock 1989, West et al. 2013). O gênero também habita costões rochosos com ampla distribuição em águas tropicais e temperadas-quentes nos Hemisférios Sul e Norte, sendo ainda encontrado em regiões temperadas-frias e subantárticas onde manguezais estão ausentes (Fontes 2012, Muangmai et al. 2014, Zuccarello et al. 2015).

O gênero compreende 142 espécies e categorias infraespecíficas, sendo 38 aceitas taxonomicamente (M.D. Guiry in Guiry \& Guiry 2015). O litoral brasileiro abriga atualmente oito espécies: B. binderi, B. calliptera, B. kelanensis Grunow, B. montagnei, B. moritziana, B. pilulifera, B. radicans e B. tenella (Joly 1965, Ugadim 1976, Cordeiro-Marino 1978, Fontes 2012, Fujii \& Cassano 2015, Zuccarello et al. 2015).

A taxonomia do gênero Bostrychia tem sido frequentemente avaliada com base em dados moleculares, acarretando mudanças nomenclaturais e rearranjos das circunscrições genéricas dentro da subfamília Bostrychieae (Zuccarello \& West 2002, 2003, 2006, 2008, Zuccarello et al. 1999a, b, 2006, 2011, 2015, Muangmai et al. 2015, West et al. 2013). Os estudos têm demonstrado que o gênero é polifilético (Zuccarello \& West 2006) e possui uma alta diversidade específica, muito maior do que previamente se supunha (Zuccarello et al. 2015). Muitas espécies são crípticas (linhagens intraespecíficas geneticamente diferentes) (Zuccarello \& West 2006, Zuccarello et al. 2011, 2015, West et al. 2013, Muangmai et al. 2014), sendo tratadas com complexos de espécies, como o complexo Bostrychia calliptera/B. pinnata J. Tanaka \& Chihara, esta última tratada atualmente como sinônimo de $B$. calliptera (Zuccarello \& West 2002, 2006), o complexo B. radicans/B. moritziana (Zuccarello et al. 2006, West et al. 2013) e o complexo B. binderi/B. tenella/B. flagellifera (King et al. 1988, Zuccarello et al. 2015).

Morfologicamente, as características empregadas na separação de espécies de Bostrychia incluem: tipo de hapteron desenvolvido para a fixação dos talos, padrão de ramificação e número de ordem de ramos, presença ou ausência de corticação nos eixos principais, presença e extensão de monossifonia ou polissifonia nos râmulos de última ordem, forma dos ápices (completamente, raramente ou nunca recurvados), diâmetro dos ramos laterais de primeira ordem, número de camadas de células pericentrais por célula axial, número de células pericentrais por célula axial, estrutura 
e tamanho das células, forma e tamanho dos estiquídios e dos cistocarpos (Falkenberg 1901, King \& Puttock 1989, Zuccarello \& West 2008, Fontes 2012).

A fixação dos talos em espécies de Bostrychia é feita por dois tipos distintos de hapteron, denominados de cladohapteron e peripherohapteron. O hapteron é formado por prolongamentos rizoidais multicelulares justapostos originados a partir de células axiais, pericentrais ou corticais, que funciona como um ramo especializado para fixação secundária (King \& Puttock 1989, Zuccarello \& West 2006). O tipo cladohapteron se origina a partir da proliferação de células axiais, pericentrais ou corticais na extremidade de ramos vegetativos de crescimento determinado ( $B$. moritziana, B. pilulifera e B. radicans) ou indeterminado (B. kelanensis), enquanto o tipo peripherohapteron se origina a partir de células pericentrais ou corticais do eixo principal no lado ventral do talo (B. calliptera, B. montagnei e B. tenella) (King \& Puttock 1989, Fontes 2012). De forma simplificada, peripherohaptera são ramos adventícios, enquanto cladohaptera são derivados da extremidade de ramos vegetativos modificados (Zuccarello \& West 2006). (Fig.8).

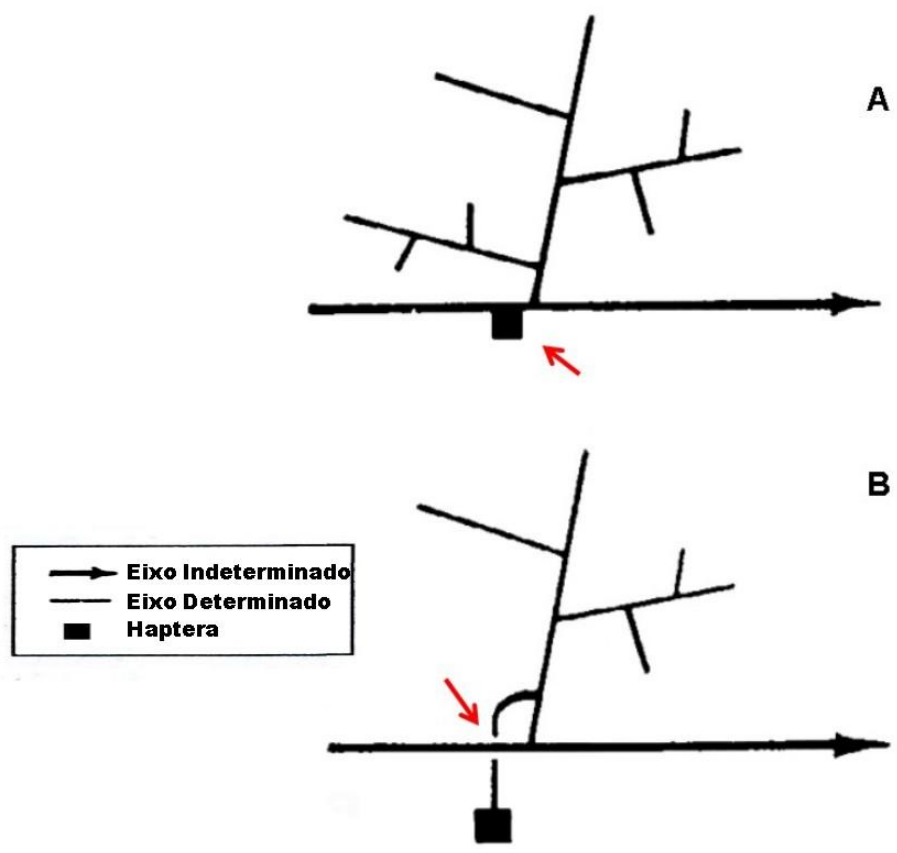

Figura 8 - Representação esquemática do desenvolvimento do haptera em Bostrychia. Seta vermelha indica local de desenvolvimento do haptera. A - Periferohaptera. B - Cladohaptera. Modificado de King \& Puttock (1989). 
De acordo com Fontes (2012), dentre as características morfológicas empregadas na taxonomia do grupo, listadas acima, o tipo de hapteron e o padrão de ramificação possuem valor diagnóstico para a separação entre espécies de Bostrychia; por outro lado, ramos monossifônicos de última ordem e número de células pericentrais por célula axial foram considerados caracteres secundários.

O valor diagnóstico do tipo de hapteron já havia sido reconhecido desde Post (1936), que dividiu as espécies do gênero em duas secções: Flagellifulcrateae (abriga espécies com cladohapteron) e Ramifulcrateae (abriga espécies com peripherohapteron). Essa é a única característica morfológica que tem sido sustentada por dados moleculares como efetiva na separação entre espécies de Bostrychia. Análises moleculares com diferentes marcadores, como 26S rRNA e rbcL (Zuccarello \& West 2006), UPA, COI-5P e rbcL (Fontes 2012) agrupam espécies com um ou outro tipo de estrutura de fixação. O mesmo resultado foi verificado neste estudo para os três marcadores utilizados, nos quais táxons com peripherohapteron formaram um agrupamento claramente separado daqueles com cladohapteron. Zuccarello \& West (2006), apoiados por seus dados moleculares, endossaram as duas seções propostas por Post (1936), Ramifulcrateae e Flagellifulcratae, baseadas morfologicamente nos tipos de hapteron.

Dentre as mudanças na taxonomia feitas para esse grupo com base em dados moleculares, destaca-se a sinonímia do gênero Stictosiphonia J.D. Hooker \& Harvey (1847) [com uma única espécie citada para o Brasil, S. kelanensis (Grunow ex E.Post) R.J.King \& Puttock] com Bostrychia Montagne (1842), efetuada por Zuccarello \& West (2006), com base em sequências parciais do 26S rRNA e rbcL. O gênero Stictosiphonia foi restabelecido por Falkenberg (1901) com base no número de células em coluna derivadas da célula periaxial (3-5 células em coluna por célula periaxial em Stictosiphonia e 2 células em coluna por célula periaxial em Bostrychia) (King \& Puttock 1989). Destaca-se ainda, o restabelecimento recente de $B$. binderi como uma espécie independente, segregada de $B$. tenella com base em quatro marcadores moleculares, rbcL, LSU, espaçador da Rubisco (rbcL-S) e espaçador cox2-3 (Zuccarello et al. 2015). Fontes (2012), em sua tese de doutorado, já havia sugerido que $B$. binderi deveria ser reconhecida como uma entidade taxonômica diferente de $B$. tenella, com base em sequências do UPA, COI-5P e rbcL. Bostrychia binderie $B$. tenella são diferenciadas principalmente pela extensão da polissifonia nos ramos de 
última ordem, sendo em $B$. binderi os ramos laterais de última ordem inteiramente ou parcialmente polissifônicos, enquanto que em $B$. tenella inteiramente monossifônicos (Post 1933, 1939, Joly 1965, Cordeiro-Marino 1978, Fontes 2012, Zuccarello et al. 2015). As duas espécies foram sinonimizadas por King et al. (1988) com base em dados morfológicos que indicavam uma variação na distribuição e comprimento dos ramos laterais monossifônicos que não distinguiam claramente a priori $B$. binderi de B. tenella.

Bostrychia calliptera é caracterizada por apresentar talo delicado com ápices nunca recurvados, estrutura de fixação do tipo peripherohapteron, ramificação alternodística com 1-3 ordens de ramos, a raramente irregular na porção basal, talo com pseudocorticação por filamentos rizoidais nos eixos prostrados, presente apenas na região do peripherohapteron e corticado no eixo principal (com 1-2 ordens de corticação), talo inteiramente polissifônico, inclusive os râmulos de última ordem; ramos laterais, longos, simples ou ramificados subdicotomicamente junto ao ápice (Joly 1954, Cordeiro-Marino 1978, Fontes 2012).

Os exemplares denominados nesse estudo como " $B$. calliptera" morfologicamente compartilham com $B$. calliptera descrita por Joly (1954), CordeiroMarino (1978) e Fontes (2012), o tipo de estrutura de fixação, o padrão de ramificação alterno-dística, a ausência de ramos recurvados e a inteira polissifonia do talo (Fig. 10A-C). Entretanto, nossos exemplares são menores e mais delicados, e não há qualquer tipo de corticação ou pseudocorticação nesses espécimes. A despeito dessas diferenças morfológicas, consideradas de pouco valor diagnóstico (King et al. 1988, Zuccarello \& West 2002), os resultados moleculares com o UPA e COI-5P sem dúvida apontam a clara separação desses dois táxons, que não se agruparam em nenhuma análise, e mostraram alta divergência genética, 6,5\% a 6,7\% para o UPA e $16,7 \%$ a $17 \%$ para o COI-5P, estando na faixa de divergência interespecífica observada entre outras espécies de Bostrychia para esse último marcador (11,9\% a $23,4 \%)$.

Zuccarello \& West (2002) avaliaram o complexo Bostrychia calliptera/B. pinnata com base em três marcadores: o espaçador cox2-3, o espaçador da Rubisco e sequências parciais do LSU. Os autores concluíram que a espécie ecorticada $B$. 
pinnata e a corticada $B$. calliptera eram sinônimos, tendo $B$. calliptera prioridade. Sugeriram ainda que pela nova circunscrição, B. callipetra era monofilética. $O$ complexo Bostrychia calliptera/B. pinnata formou três linhagens que não eram separáveis com base na presença ou ausência de corticação, critério já considerado inconsistente para a taxonomia do gênero Bostrychia (King et al. 1988).

A linhagem denominada 1 por Zuccarello \& West (2002) agrupou duas sequências brasileiras com morfologia B. pinnata (ecorticada) (C3648, Maranhão e C3065, São Paulo, Ilha do Cardoso, Rio Perequê). A linhagem denominada 3 por Zuccarello \& West (2002) também agrupou duas sequências brasileiras: C3042, com morfologia B. calliptera (corticada) e C3066, com morfologia B. pinnata (ecorticada), ambas da llha do Cardoso, Rio Sítio Grande.

Posteriormente Zuccarello \& West (2006), por meio de uma maior amostragem e dados de sequências parciais de 26S rRNA, afirmaram que não havia suporte para o monofiletismo de $B$. calliptera, que foi dividida em três linhagens: uma com amostras do Brasil e Austrália (L1), outra com uma sequência de Cingapura (L2) e uma terceira com amostras do Brasil e México (L3). Para o rbcL, Zuccarello \& West (2006) não tiveram sucesso na obtenção sequências das linhagens $L 1$ e $L 2$, mesmo após várias tentativas. O mesmo ocorreu com as nossas amostras de "B. calliptera" cujas inúmeras tentativas de sequenciamento do $r b c L$ falharam, ou por dificuldade na amplificação do DNA ou por contaminação das amostras. As sequências de rbcL da linhagem L3 de Zuccarello \& West (2006) foram incluídas nas nossas análises (AY920806 - México e AY920805 (C3042 - Brasil, Ilha do Cardoso, Rio Sítio Grande), e não se agruparam com " $B$. calliptera".

Nossas amostras de " $B$. calliptera" possuem morfologia " $B$. pinnata" pela combinação dos caracteres, talo ecorticado e ramificação alterno-dística. A obtenção de sequências do $r b c L$ e de outros marcadores como os utilizados por Zuccarello \& West $(2002,2006)$ é necessária para comparação das sequências e esclarecimento do posicionamento de " $B$. calliptera", se dentro das linhagens já identificadas por esses autores ou não. Como base nos agrupamentos genéticos verificados para $B$. calliptera com diferentes marcadores (Zuccarello \& West 2002, 2006, este estudo), a espécie poderia ser separada em três espécies distintas. Vale ressaltar que não há sequências da localidade tipo de "B. pinnata" (Japão) e B. calliptera (Cayenne, Guiana Francesa) disponíveis nos bancos de dados. 
Dentre as espécies de Bostrychia estudadas neste trabalho, B. montagnei (Fig. 11A-D) pode ser considerada a de mais fácil identificação morfológica. A espécie possui talo muito robusto, fixação por peripherohaptera, ápices fortemente recurvados ventralmente, ramificação alterno-dística com 2-4 ordens de ramos, eixos principais e ramos laterais corticados e râmulos de última ordem parcialmente monossifônicos.

Molecularmente, B. montagnei formou agrupamentos bem apoiados em todas as análises e apresentou baixa divergência intraespecífica (0\%-0,8\%) para a análise com o gene rbcL, na qual foram incluídas amostras do Caribe e Pacífico. Essa divergência (<1\%) está na faixa de variação intraespecífica para esse marcador para outros gêneros de Rhodomelaceae (Cassano 2009, Cassano et al. 2009, Díaz-Larrea et al. 2007). Embora não haja sequências da localidade tipo (EUA, Flórida, Key West) disponíveis nos bancos de dados, a baixa divergência encontrada ( $0 \%$ a $0,17 \%$ ) entre a sequência do Panamá, local mais próximo à localidade-tipo, e as sequências brasileiras (nossas e do GenBank) e a do Pacífico (El Salvador), indicam que $B$. montagnei é uma espécie genética e morfologicamente bem definida, conforme já mencionado por Fontes (2012) e Zuccarello et al. (2015), e corroborado pelos nossos resultados. Intrigante é a maior divergência intraespecífica $(0,8 \%)$ observada entre amostras de Santa Catarina e Pernambuco de Fontes (2012) e as demais, bem maior do que as encontradas entre o Pacífico e o Caribe.

A espécie $B$. radicans é caracterizada pela fixação do talo por cladohapteron, ramificação alterna com 1-2 (-3) ordens de ramos, talo inteiramente ecorticado e inteiramente polissifônico, podendo ser monossifônico apenas no terço superior do râmulo com 2 a 5 células unisseriadas. A Figura 12 mostra espécimes de $B$. radicans 1 e B. radicans 2. Diferenças no padrão de ramificação e maior tamanho do talo distinguem $B$. radicans 1 de $B$. radicans 2 . Talos maiores foram observados em $B$. radicans $2(3 \mathrm{~cm})$, enquanto que em $B$. radicans 10 talo não ultrapassou $1 \mathrm{~cm}$. Espécimes de $B$. radicans 2 possuem ramificação alterno-dística mais densa, enquanto que em $B$. radicans 1 a ramificação é mais esparsa. As Figuras 13A-E e 14A-D mostram espécime e estruturas reprodutivas de $B$. radicans 2 .

Essa espécie é distinta de $B$. moritziana apenas pelos ramos de última ordem que são monossifônicos nesta última (Joly 1965 e Cordeiro-Marino 1978 (como B. 
radicans f. moniliforme Post), King \& Puttock 1989, Fontes 2012, Almeida 2013). A forma moniliforme de $B$. radicans foi elevada à categoria específica como $B$. moritziana por King \& Puttock (1989). Nossos espécimes denominados de $B$. moritziana 2 (Fig. 15A-D) são semelhantes morfologicamente aos de Fontes (2012), denominados B. moritziana 1, por apresentarem talos com râmulos dicotômicos inteiramente monossifônicos. Porém, nossos espécimes ilustrados na Figura 15A-D, que representam a linhagem $B$. moritziana 2, são mais delicados possuindo eixo prostrado conspícuo e eixos eretos esparsos e menos ramificados.

O valor taxonômico da característica (monossifonia ou polissifonia dos râmulos) foi questionado por Pedroche et al. (1995) e Zuccarello \& West $(1995,1997,2003)$ ao observaram variabilidade em isolados cultivados de $B$. moritziana que desenvolveram ramos de última ordem inteiramente polissinônicos, ou $B$. radicans, cujos isolados desenvolveram ramos monossifônicos. Apesar dessa variabilidade em condições experimentais, de acordo com Fontes (2012) a presença de ramos monossifônicos de última ordem em $B$. moritziana foi um carácter útil na separação de $B$. radicans nos representantes brasileiros. $O$ mesmo foi observado nos nossos espécimes.

Estudos moleculares realizados com $B$. radicans e $B$. moritziana com base nos espaçadores cox 2-3 e espaçador da Rubisco ( $r b c \mathrm{~L}-\mathrm{S}$ ) revelaram espécies crípticas para ambos os táxons que formam um complexo, compreendendo sete linhagens moleculares (Zuccarello \& West 2003, 2006, Zuccarello et al. 2006, West et al. 2013). Estudos de hibridização com diferentes isolados de $B$. radicans e $B$. moritziana revelaram hibridização negativa entre essas duas espécies (Zuccarello \& West 1995, 1997, Zuccarello et al. 1999b, 2011), mas compatibilidade entre isolados de uma mesma espécie, que são próximos molecularmente (0 a 1 pb divergente do rbcL-S, entre, por exemplo, isolados de $B$. radicans do Brasil (SP) e entre isolados do Brasil e Peru; entre isolados de B. moritziana da Austrália e África do Sul) (Zuccarello \& West 1997).

Estudos posteriores com uma maior amostragem do complexo $B$. radicans/ $B$. moritziana confirmaram que as diferenças das populações não podem ser explicadas por isolamento por distância, uma vez que dados de hibridação sugeriram que, enquanto haplótipos do Pacífico (México, Guatemala, El Salvador) são, pelo menos, 
parcialmente compatíveis, o mesmo haplótipo do Atlântico (EUA) é majoritariamente incompatível reprodutivamente (Zuccarello et al. 2011). Os autores concluíram que a maior parte da variação no complexo $B$. radicans/B. moritziana do sul da América Central é devido à retenção dessa diversidade após o fechamento do Istmo do Panamá, também observaram que as populações de manguezais são altamente diferenciadas, e que especiação (fases iniciais de incompatibilidade reprodutiva) ocorre em taxas mais rápidas do que o marcador molecular utilizado ( $r b c \mathrm{~L}-\mathrm{S}$ ).

Entretanto, as sete linhagens moleculares do complexo B. radicans/B. moritziana evidenciadas por Zuccarello \& West (2003, 2006), Zuccarello et al. (2006) não são inter-compatíveis reprodutivamente e o número de espécies crípticas é alto (Zuccarello \& West 1995, 1997, Zuccarello et al. 1999b, 2011). Das sete linhagens moleculares identificadas por esses autores, três delas possuem amostras brasileiras de $r b c L-S$, procedentes da Ilha do Cardoso (SP) (linhagens 3, 5 e 6), e uma de Trindade (RJ) (linhagem 3) (Zuccarello \& West 2003, West et al. 2013). As linhagens 5 e 6 incluem amostras brasileiras com morfologia de $B$. radicans, enquanto a linhagem 3 inclui amostras brasileiras com morfologia de $B$. radicans e B. moritziana.

Duas linhagens diferentes de $B$. radicans foram observadas por Fontes (2012) usando marcadores moleculares (UPA e rbcL) com base em amostragens para uma grande extensão da costa brasileira (linhagem 1 abrangendo amostras do Pará a Santa Catarina e linhagem 2 com amostras da Bahia).

Os nossos resultados baseados apenas em sequências da llha Barnabé, Santos evidenciaram duas linhagens de $B$. radicans com o UPA e três linhagens com o rbcL e COI-5P, cuja divergência foi alta para os três marcadores. Nossas amostras IB08, IB43, IB63 e IB83 fazem parte da linhagem 6 de Zuccarello \& West $(2003,2006)$ e West et al. (2003), cujo isolado 2649 (São Sebastião, SP) teve o rbcL sequenciado (AY920818) e agrupou-se com nossas sequências. Correlações com as demais linhagens identificadas por esses autores não puderam ser feitas pela ausência de sequências comuns. Uma análise futura com o rbcL-S entre as nossas amostras e as obtidas por esses autores podem ajudar a esclarecer se as nossas demais linhagens correspondem as já detectadas em trabalhos anteriores ou se há outras linhagens moleculares para o complexo $B$. radicans/B. moritziana. Para as amostras de $B$. moritziana, duas linhagens moleculares foram observadas com o UPA, entretanto não 
foi possível detectar diferentes linhagens dessa espécie com os marcadores COI-5P ou rbcL por dificuldades de amplificação desses marcadores.

A utilização dos três marcadores moleculares permitiu uma separação eficiente para o gênero Bostrychia, com praticamente os mesmos agrupamentos identificados, contudo como já evidenciado em estudos anteriores, o UPA mostrou-se um marcador mais conservado, com divergência genética mais baixa e menor detecção de linhagens moleculares em comparação com os dois outros marcadores utilizados.

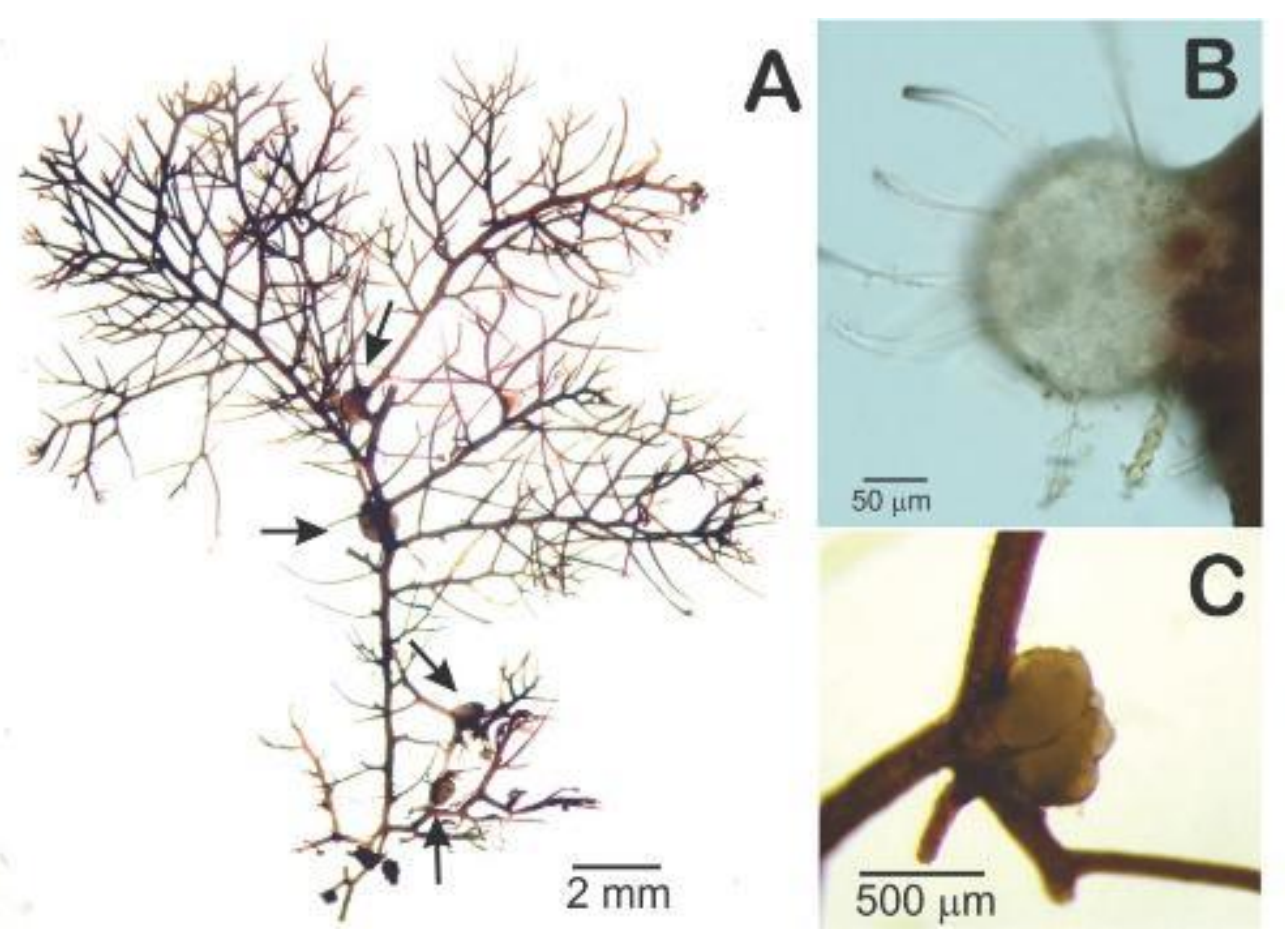

Figura 9 - Dawsoniocolax bostrychiae. Aspecto geral da parasita (setas) sobre B. radicans 2. B- Aspecto geral de uma planta feminina com várias tricogines. C-Detalhe da parasita aderida ao talo de B. radicans 2 

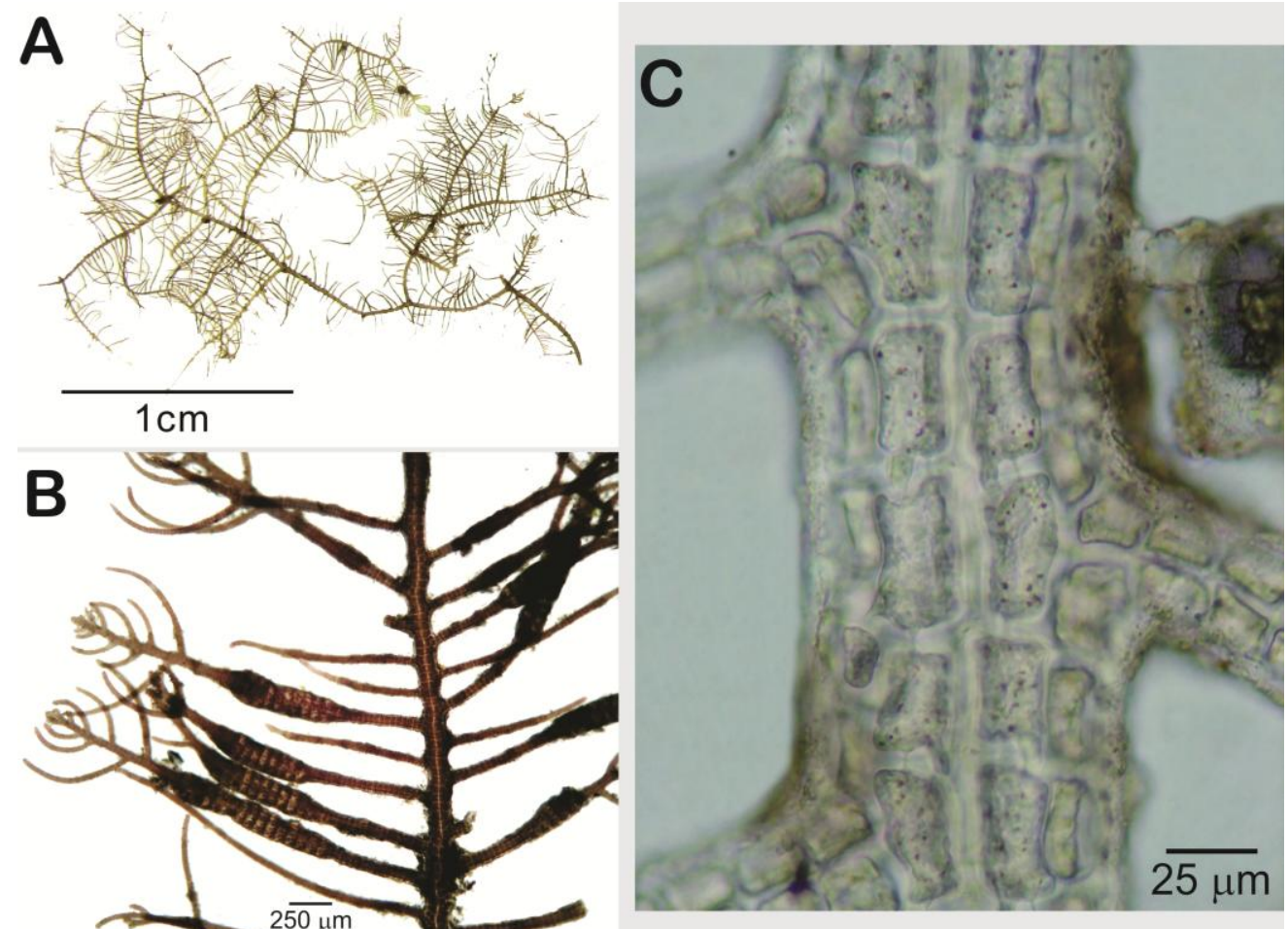

Figura 10 - "Bostrychia calliptera". A-Aspecto geral do talo. B-Detalhe dos râmulos com estiquídios. C-Detalhe do eixo principal ecorticado.

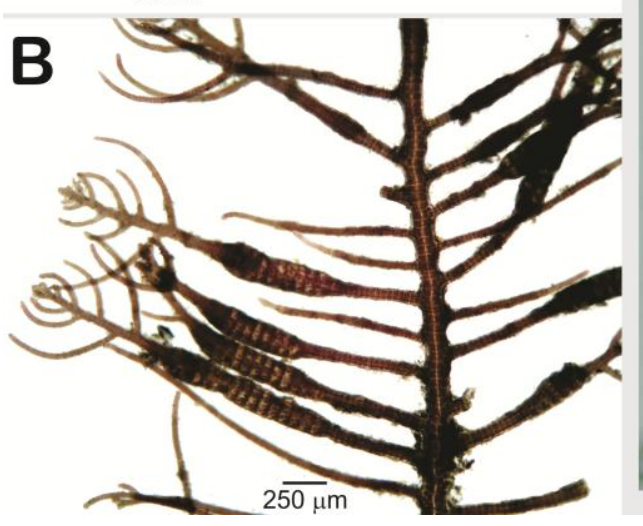

A
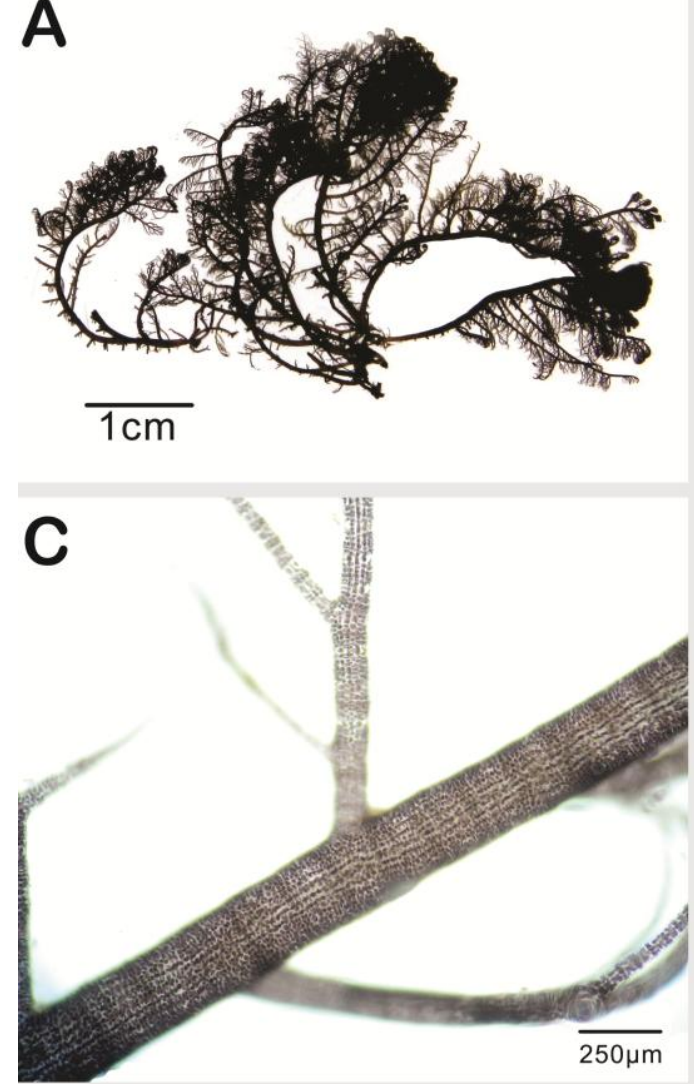

B
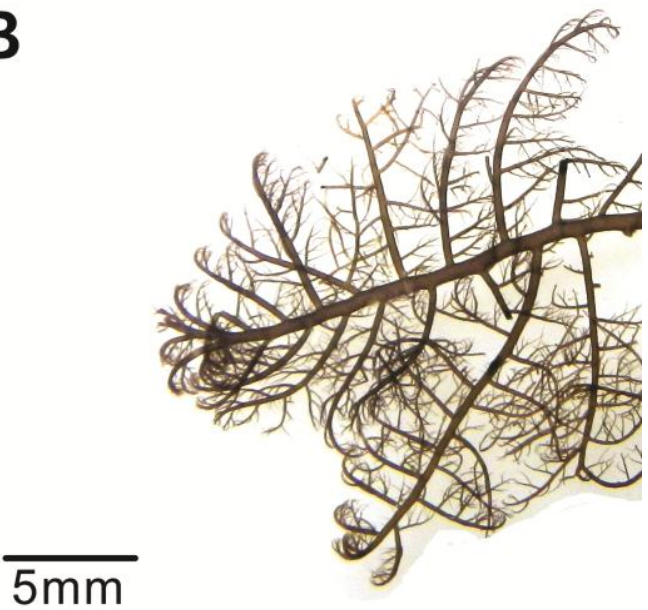

D

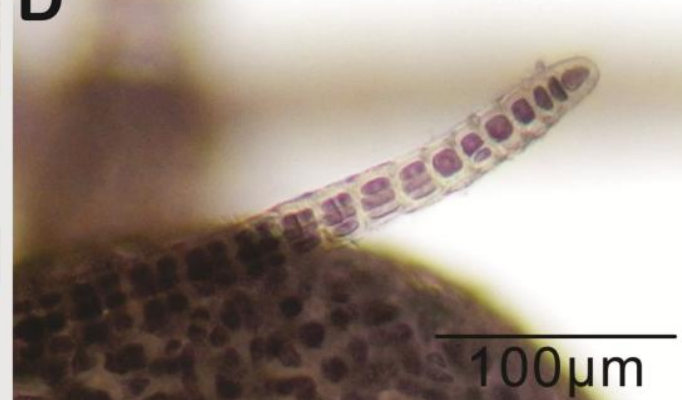

Figura 11 - Bostrychia montagnei. A-Aspecto geral do talo. B-Detalhe do ápice recurvado. C-Detalhe do ramo corticado. D-Detalhe do râmulo de última ordem parcialmente monossifônico. 
A

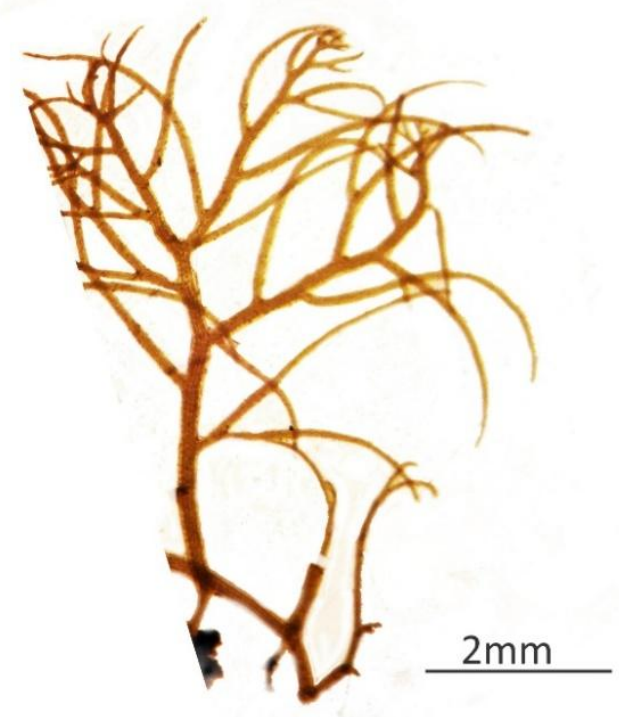

B

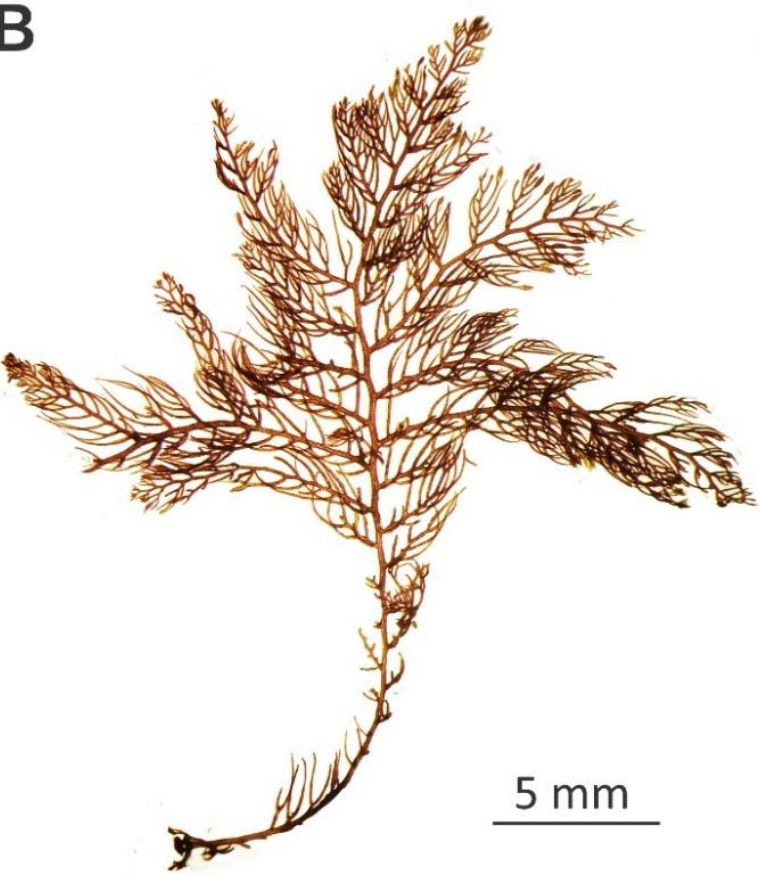

Figura 12 - Comparação entre espécimes de Bostrychia radicans. A- B. radicans 1. B- B. radicans 2.

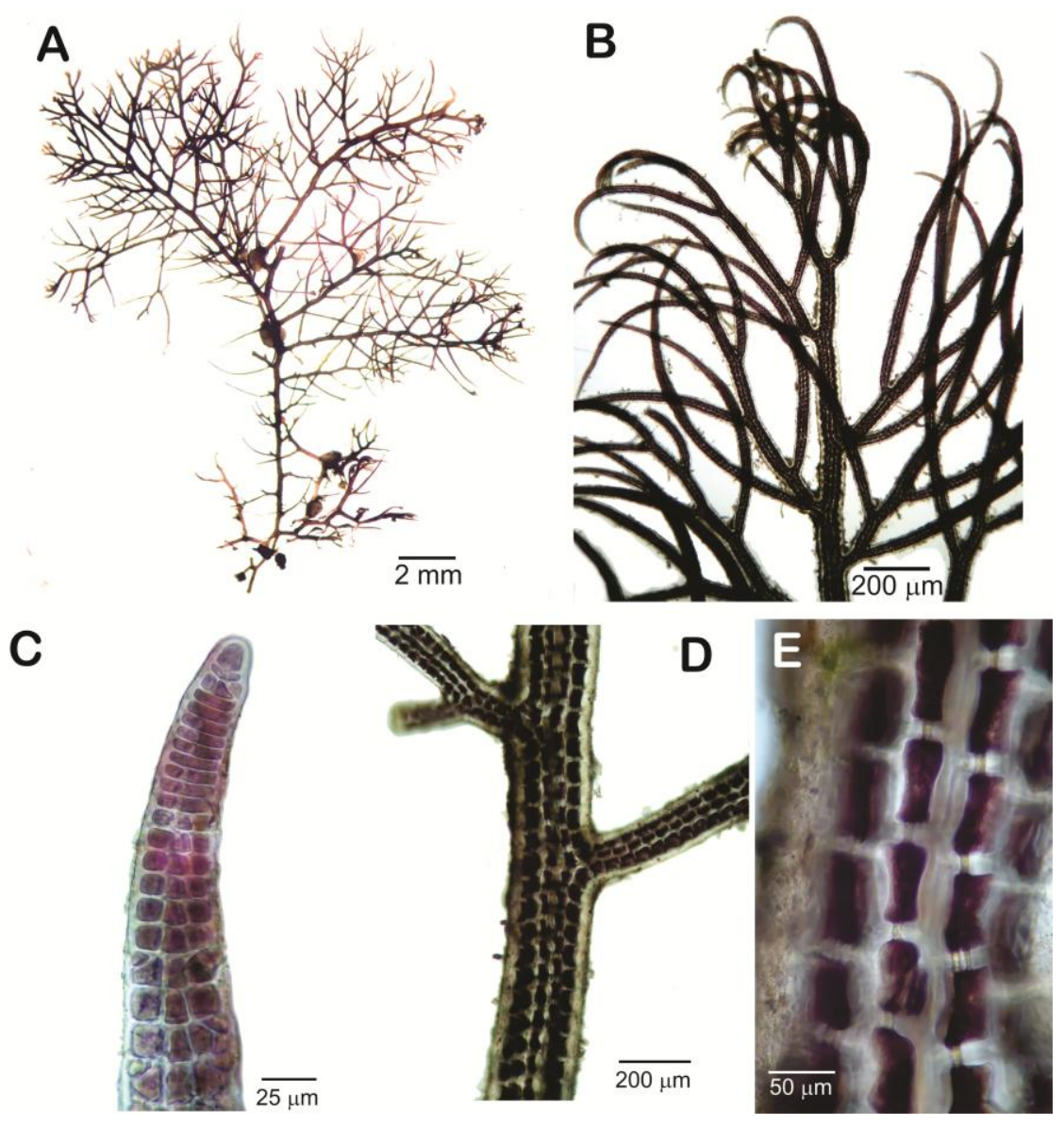

Figura 13 - Bostrychia radicans 2. A- Aspecto geral do talo. B- Detalhe do ápice e padrão de ramificação. CDetalhe ápice polissifônico. D- Detalhe do ramo lateral primário ecorticado. E- Detalhe do talo mostrando ecorticação. 
A

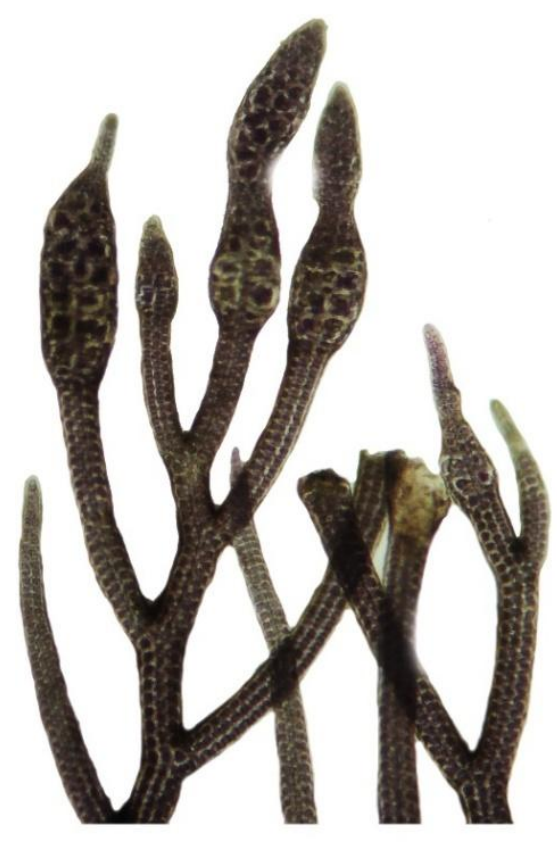

C
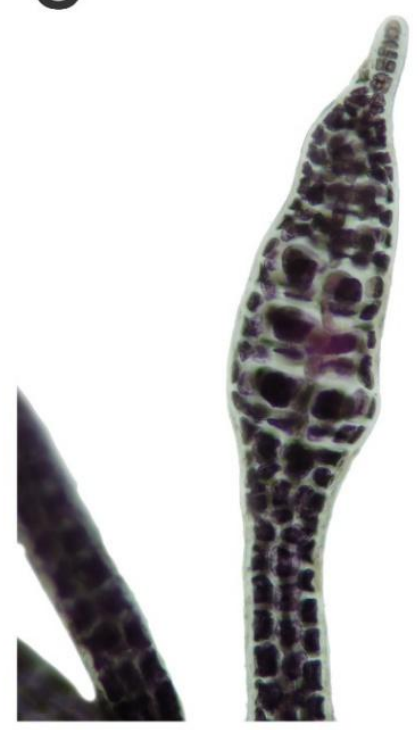

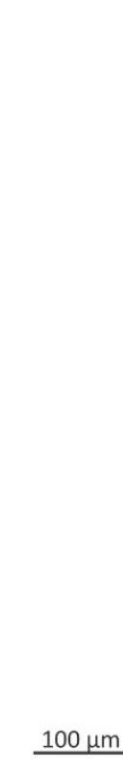

$\underline{250 \mu \mathrm{m}}$

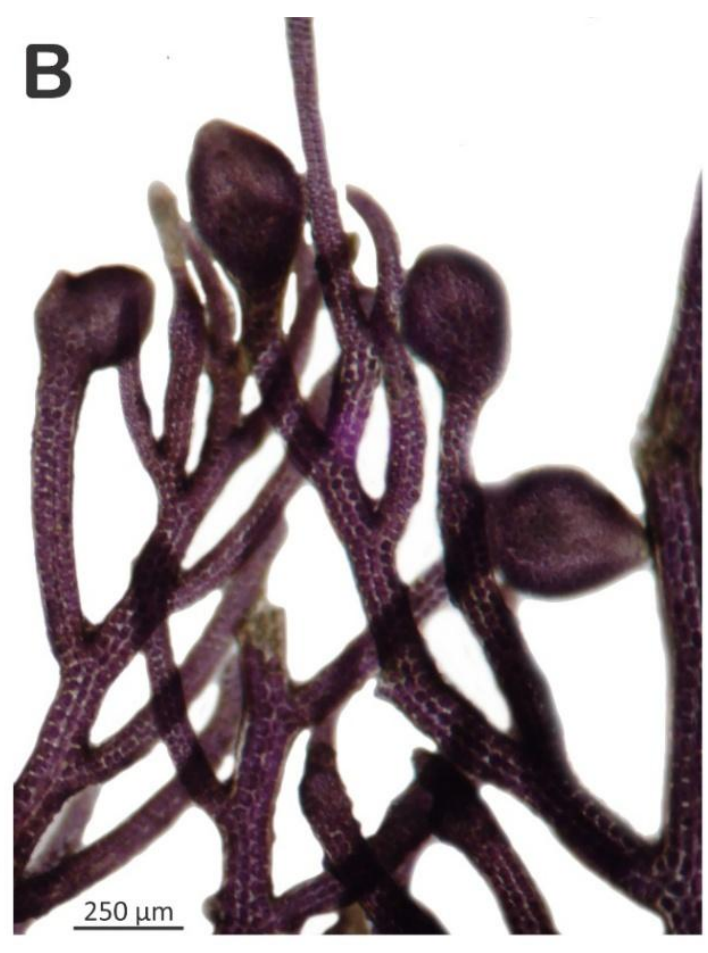

D
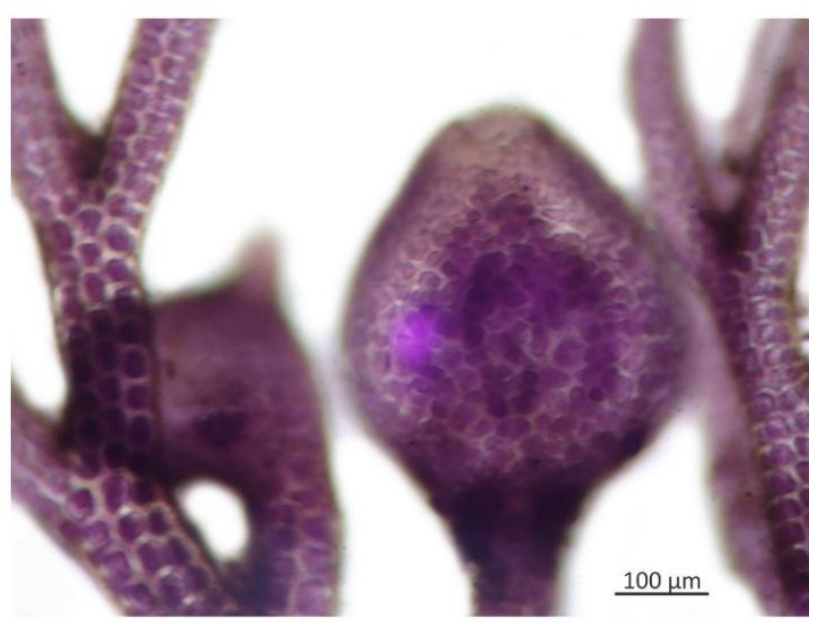

Figura 14 - Bostrychia radicans 2. A- Ápices com estiquídios. B- Ápices com cistocarpos. C- Detalhe de um estiquídio. D- Detalhe de um cistocarpo. 


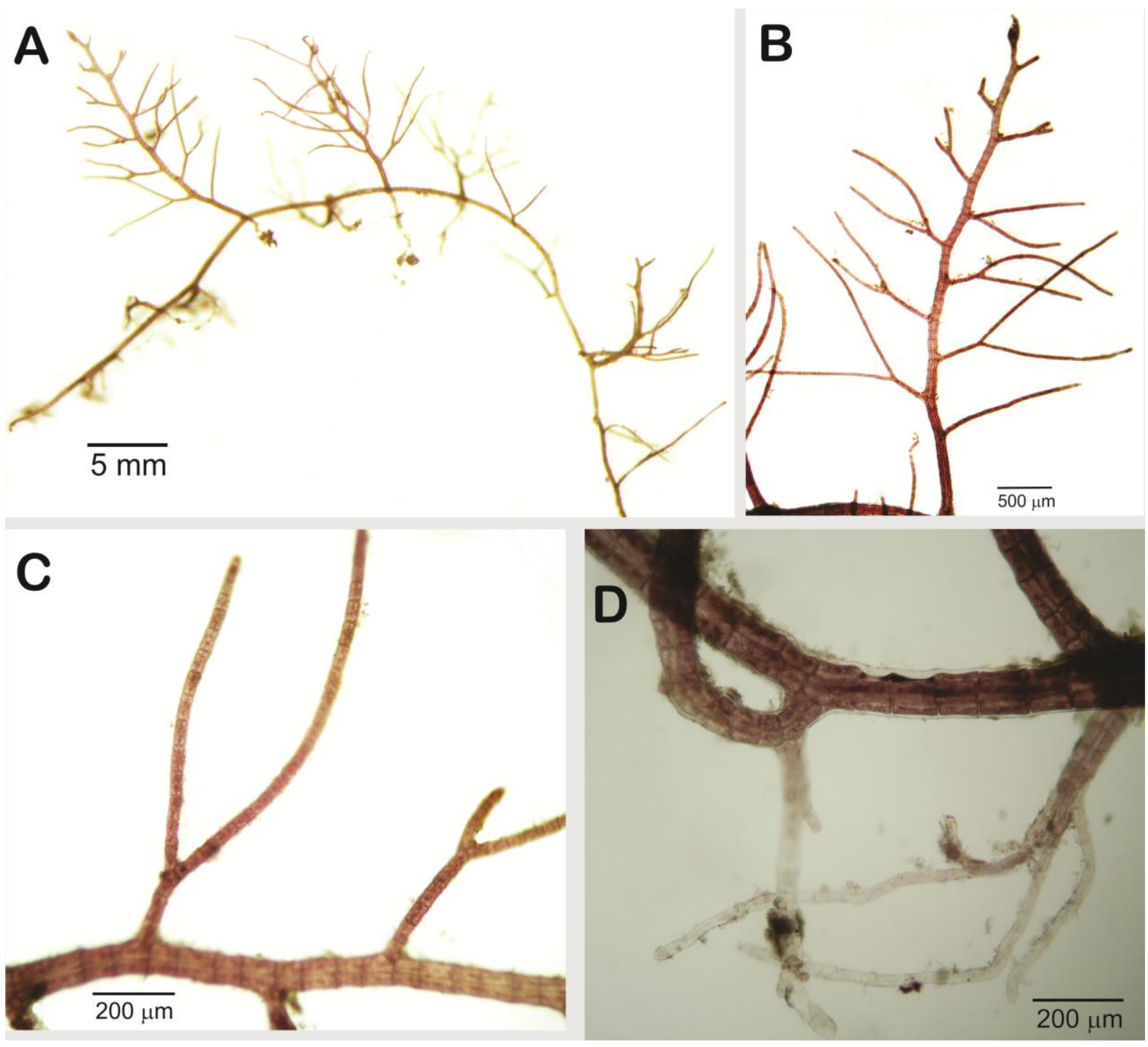

Figura 15 - Bostrychia moritziana 2. A- Aspecto geral do talo. B- Detalhe do padrão de ramificação. C- Detalhe do talo ecorticado e râmulo de última ordem inteiramente monossifônico. D- Detalhe do cladohaptera. 


\subsubsection{Gênero Caloglossa (Harvey) G. Martens}

Para a análise molecular com o marcador UPA para o gênero Caloglossa foi gerada uma matriz com 9 sequências, sendo seis obtidas neste estudo e três Delesseriaceae procedentes do GenBank, usadas como grupos externos: Martensia fragilis Harvey (EF426604), Hypoglossum rhizophorum D.L. Ballantine \& M.J. Wynne (HQ421597) e Nitophyllum adhaerens M.J. Wynne (HQ421063), gerando um alinhamento final de 369 pb. Não há sequências de UPA para Caloglossa disponíveis nos bancos de dados para comparação e também não foi possível obter sequências desse marcador para a espécie $C$. leprieurii.

A árvore de $\mathrm{NJ}$ é mostrada na Figura 16. As nossas amostras formaram dois agrupamentos representados pelas espécies $C$. confusa e $C$. ogasawaraensis, ambos com $100 \%$ de suporte. Caloglossa apomeiotica permaneceu em um ramo isolado, entretanto mais próxima de $C$. confusa. As amostras de $C$. ogasawaraensis foram $100 \%$ idênticas, enquanto $C$. confusa apresentaram baixa divergência intraespecífica ( $0 \%$ a 0,27\%, 1 pb). A amostra de C. apomeiotica divergiu de $C$. confusa de 3,5\% (13 pb) a 3,8\% (14 pb) e de C. ogasawaraensis em 5,9\% (21 pb). A divergência interespecífica entre todas as amostras estudadas variou de 3,5\% entre $\mathrm{C}$. apomeiotica e $C$. confusa a 8,4\% (31 pb) entre C. confusa e C. ogasawaraensis. 


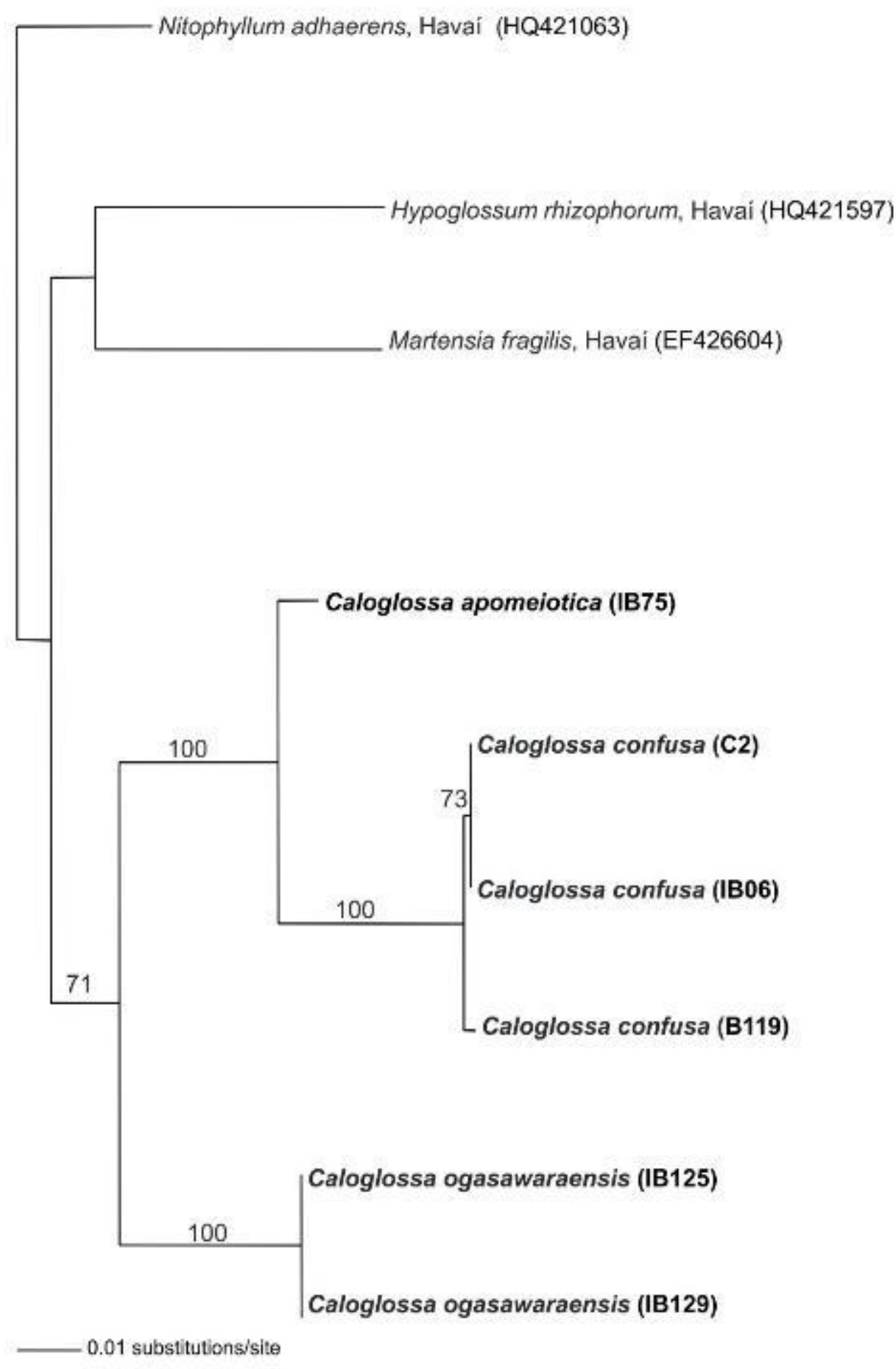

Figura 16 - Árvore de Neighbor-Joining (NJ) para as sequências do marcador UPA para o gênero Caloglossa. Apenas valores de bootstrap maiores que $70 \%$ (2000 réplicas) estão representados nos ramos. As sequências obtidas neste estudo estão representadas em negrito na árvore e a sequência retirada do Genbank está seguida do local de coleta e do número de acesso.

Para análise com o marcador COI-5P foi gerada neste estudo apenas uma sequência, C. ogasawaraensis (IB125). Houve grande dificuldade de se obter 
sequências desse marcador para o gênero Caloglossa ou pela difícil amplificação dos fragmentos ou pela ocorrência de contaminação. Para análise com o COI-5P foi gerada uma matriz com oito sequências, uma obtida neste estudo, seis de Kano (2015) e uma Delesseriaceae foi usada como grupo externo, Apoglossum ruscifolium (Turner) J. Agardh (KJ960334), gerando um alinhamento final de 574 pb. A Figura 17 mostra a análise de NJ para o COI-5P, na qual dois agrupamentos foram resolvidos com alto suporte (100\%), representados pelas espécies $C$. confusa e $C$. leprieurii. A amostra de $C$. ogasawaraensis permaneceu em um ramo isolado. As amostras de $C$. confusa (Ubatuba, SP) se agruparam e não apresentaram divergência intraespecífica. As amostras de $C$. leprieurii da llha do Mel, Paraná divergiram em apenas 0,01\% (1 pb). Os dados do COI-5P indicaram uma divergência interespecífica variando de 2,5\% (14 pb) entre $C$. apomeiotica e $C$. leprieurii a 3,3\% (19 pb) entre $C$. apomeiotica e $C$. confusa.

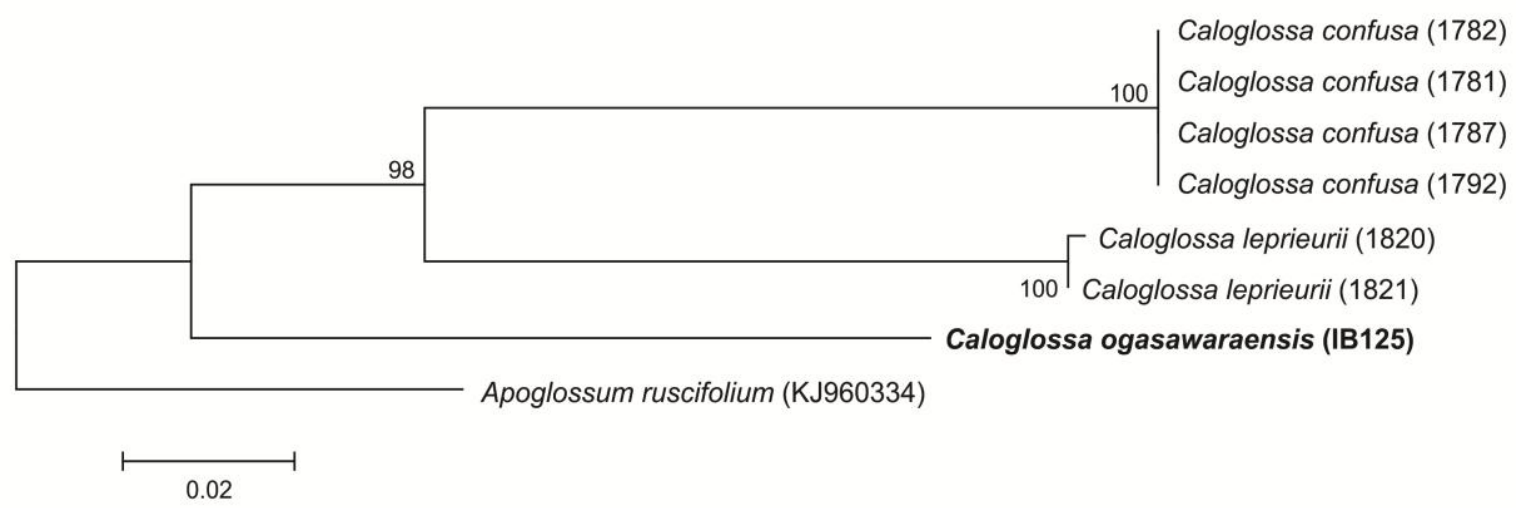

Figura 17 - Árvore de Neighbor-Joining (NJ) para as sequências do marcador COI-5P para o gênero Caloglossa. Apenas valores de bootstrap maiores que $70 \%$ (2000 réplicas) estão representados nos ramos. As sequências obtidas neste estudo estão representadas em negrito na árvore e a sequência retirada do Genbank está do número de acesso.

A análise com o rbcL foi feita a partir de uma matriz com 43 sequências, sendo cinco completas obtidas neste estudo, 12 por Kano (2015) e as demais procedentes do GenBank. A amostra Apoglossum ruscifolium (AF312310) foi usada como grupo externo. O alinhamento final consistiu de $1431 \mathrm{pb}$. Esse marcador foi de difícil amplificação e ocorreu uma elevada incidência de contaminação em amostras de diferentes espécies o que inviabilizou a obtenção de mais sequências. 
A Figura 18 mostra a árvore consenso de $r b c L$ para esse gênero. $O$ monofiletismo do gênero Caloglossa não foi sustentado por nenhuma análise.

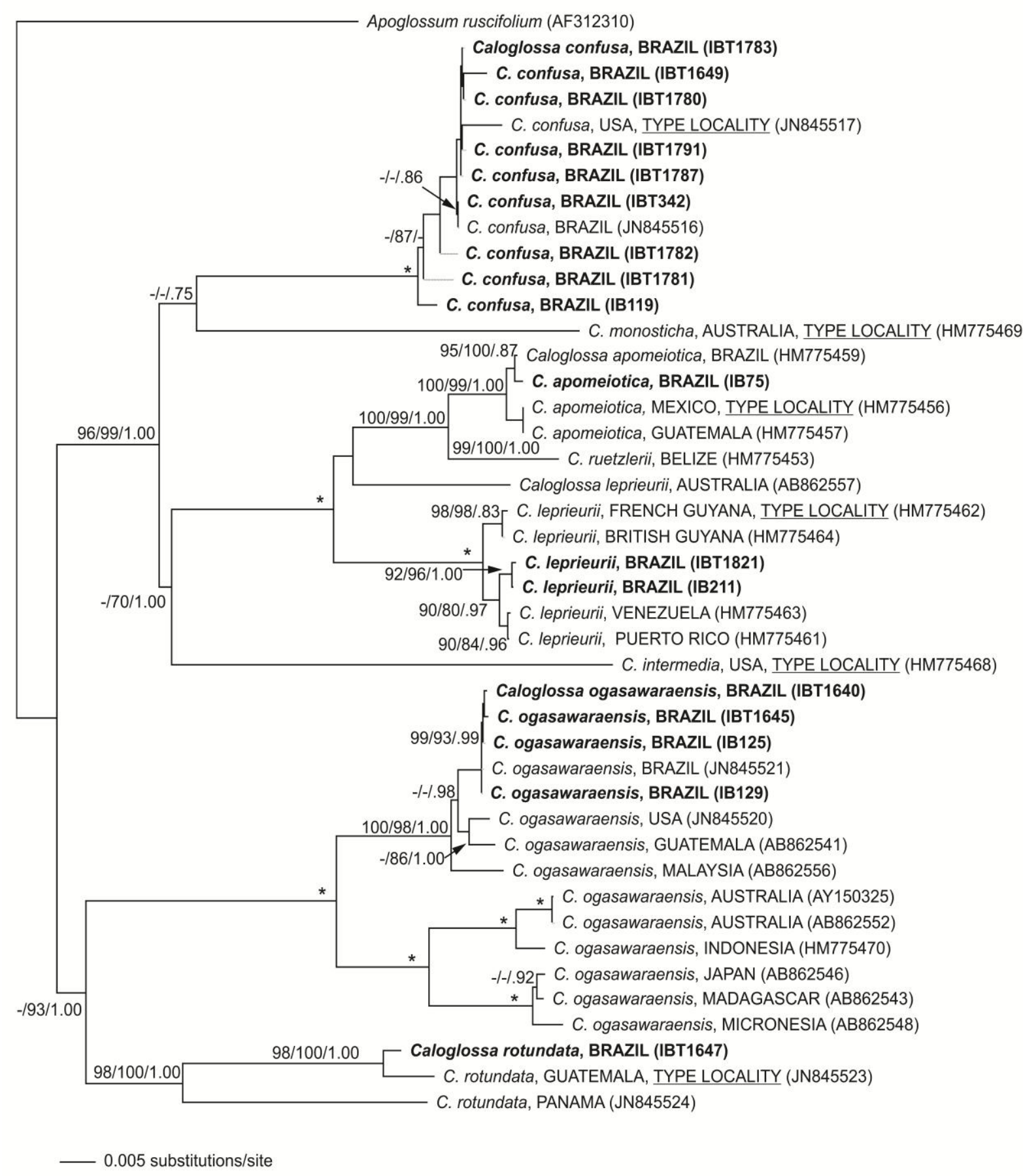

Figura 18 - Árvore consenso derivada da análise de Neighbor-Joining (NJ) para as sequências de rbcL das espécies de Caloglossa. Nos ramos estão plotados os valores de Bootstrap para as análises de Neighbor-Joining (NJ), Máxima verossimilhança (ML) e Inferência bayesiana (BI). Valores menores que $70 \%$ (ou .70 probabilidade) estão representados como $(-)$. Asterisco $\left({ }^{*}\right)$ indica suporte total para todas as análises. As sequências obtidas neste estudo estão representadas em negrito na árvore e as sequências retiradas do GenBank estão seguidas do local de coleta e do número de acesso. (Kano et al. 2016, submetido, Apêncide B). 
O gênero foi dividido em dois clados principais: o primeiro deles contendo $C$. apomeiotica, C. leprieurii, C. confusa, C. ruetzlerii Krayesky, Fredericq \& J.N. Norris, C. monosticha e $C$. intermedia, com alto suporte para todas as análises, e o segundo clado incluiu $C$. ogasawaraensis e $C$. rotundata, com alto suporte apenas para BI.

Caloglossa confusa formou um clado bem apoiado em todas as análises, com divergência intraespecífica variando de $0 \%$ a 1,3\% (19 pb). As sequências brasileiras de $C$. confusa se agruparam com a sequência da localidade tipo (Plantation Key, Flórida, EUA, JN845517) variando de 0,5\% (7 pb) a 1,3\% (19 pb).

$\mathrm{O}$ agrupamento formado por $C$. apomeiotica apresentou alto suporte em todas as análises e mostrou a mais baixa divergência intraespecífica entre as espécies estudadas $(0 \%$ a $0,4 \%, 6 \mathrm{pb})$. As amostras brasileiras (IB75, llha Barnabé e HM775459, Rio de Janeiro) divergiram em apenas 0,1\% (2 pb). A sequência de $C$. apomeiotica do Brasil obtida neste estudo divergiu da amostra da localidade tipo (Baja California Sur, México, HM775456) em apenas 0,4\%.

As amostras de $C$. leprieurii formaram um agrupamento com amostras da América do Sul (Brasil, Venezuela, Guiana, Guiana Francesa) e Caribe (Porto Rico) com alto suporte em todas as análises. As duas amostras brasileiras procedentes de SP (Ilha Barnabé e Cibratel, Itanhaém) mostraram baixa divergência intraespecífica $0,07 \%$ (1 pb). As amostras brasileiras divergiram da amostra da localidade tipo (Guiana Francesa, HM775462) de 0,7\% (10 pb) a 0,8\% (11 pb). Caloglossa leprieurii apresentou a maior divergência intraespecífica entre as espécies do gênero estudadas (4,7\%, $67 \mathrm{pb}$ ) entre uma amostra da Austrália (AB862557) e a amostra brasileira (IBT1821). A amostra australiana não se agrupou com as demais amostras de $C$. leprieurii e divergiu da amostra da localidade tipo em 4,6\% (66 pb), indicando que se trata provavelmente de um erro de identificação.

As amostras de $C$. ogasawaraensis foram divididas em três clados correspondentes aos verificados por Kamiya \& West (2014). As amostras brasileiras formaram um subclado com suporte alto a moderado e divergiram entre si de $0 \%$ a $0,07 \%$. As amostras brasileiras se agruparam com sequências dos EUA, Guatemala e Malásia com baixa divergência intraespecífica ( $0 \%$ a $0,8 \%$ ). A divergência para todas as amostras de C. ogasawaraensis variou de $0 \%$ a 5,2\% (75 pb). Não há sequências da localidade tipo (Ogasawara-jima, Bonin Islands) disponíveis para comparação. 
A amostra brasileira de $C$. rotundata divergiu em 0,9\% (13 pb) da amostra da localidade tipo (Likin, Guatemala, JN845523). A amostra do Panamá (JN845524) apresentou maior divergência com as amostras brasileira e guatemalteca $(6,5 \%, 93$ $\mathrm{pb})$.

Os dados obtidos com o gene rbcL indicam uma distinção molecular entre as espécies de Caloglossa variando de 2,5\% (35 pb) entre $C$. apomeiotica e $C$. ruetzlerii a 14,5\% (207 pb) entre C. ogasawaraensis e C. intermedia.

O gênero Caloglossa compreende atualmente 39 espécies, incluindo categorias infraespecíficas, das quais 20 são aceitas taxonomicamente (Guiry in Guiry \& Guiry 2016). O gênero habita principalmente manguezais em regiões tropicais e temperadas quentes do mundo com algumas espécies apresentando distribuição pantropical, enquanto outras possuem distribuição mais restrita, como $C$. fluviatilis Krayesky, Fredericq \& J.N. Norris, uma espécie de água doce encontrada apenas no Panamá (Krayesky et al. 2011, 2012).

O gênero Caloglossa possui morfologia muito simples, sendo caracterizado por um talo composto por delicadas lâminas regularmente constritas em maior ou menor grau, monostromáticas, exceto na nervura central. A sistemática do gênero tem sido intensamente investigada, entretanto a diversidade de espécies ainda não foi completamente esclarecida (Kamiya et al. 1999, 2003, Krayesky et al. 2011, 2012, Kamiya \& West 2014).

De acordo com Kano \& Fujii (2016), o litoral brasileiro abriga cinco espécies de Caloglossa: C. apomeiotica, C. confusa, C. leprieurii, C. monosticha M. Kamiya e C. ogasawaraensis. Entretanto, Krayesky et al. (2012) ao estudarem as espécies americanas do gênero com base nos genes $r b c$ e LSU rDNA demonstraram que a espécie identificada anteriormente como C. monosticha para o Atlântico ocidental, correspondia uma espécie nova, descrita como $C$. confusa, que difere de $C$. monosticha do Oceano Pacífico principalmente pelo seu talo com nós fortemente constritos. Desta forma, atualmente, quatro espécies de Caloglossa são referidas para o Brasil, excluindo C. monosticha.

Os estudos de Caloglossa no litoral brasileiro, assim como de toda a família Delesseriaceae, são baseados, em sua grande maioria, em análises morfológicas. Estudos aplicando técnicas moleculares são muito recentes e foram iniciados por 
Kano (2015) ao investigar as Delesseriaceae do sudeste brasileiro utilizando marcadores do tipo "DNA Barcode" (COI-5P e UPA) e o gene rbcL. Os resultados obtidos para Caloglossa por Kano (2015) foram somados aos nossos em um artigo submetido ao Brazilian Journal of Botany (em revisão). Cinco espécies foram confirmadas para o Brasil com base em dados morfológicos e moleculares: $C$. apomeiotica, C. confusa, C. leprieurii, C. ogasawarensis e C. rotundata M. Kamyia. Com exceção de $C$. rotundada, todas as demais espécies foram encontradas na llha Barnabé. A ocorrência de $C$. rotundada no litoral brasileiro a partir de material coletado em Ubatuba, SP, consiste na sua primeira citação para o Oceano Atlântico (Kano et al. 2016, submetido).

Nossos resultados moleculares obtidos com o rbcL não apoiaram 0 monofiletismo do gênero Caloglossa, entretanto os grupos genéticos representados pelas cinco espécies sequenciadas tiveram alto suporte em todas as análises (Fig. 18). Krayesky et al. (2012) pontuaram que as análises com o rbcL e LSU revelaram que Caloglossa é um gênero monofilético, porém sem forte apoio para qualquer análise. De fato, na árvore de rbcL de Krayesky et al. (2012) não há suporte para o monofiletismo do gênero em nenhuma análise, semelhante aos nossos resultados. $\mathrm{A}$ divisão do gênero em dois grupos principais corrobora os resultados obtidos por Krayesky et al. (2012). Os valores de divergência intraespecífica obtidos neste estudo (0,5\%-1,3\%) são comparáveis aos verificados por Krayesky et al. (2012) para o gene $r b c L(0,4 \%-1,5 \%)$. Igualmente, a variação interespecífica observada neste estudo (2,5\%-14,5\%) está na faixa descrita por Krayesky et al. (2012) para Caloglossa (2,7\%$14,1 \%)$.

A distinção de espécies de Caloglossa é feita principalmente por características morfológicas vegetativas, sendo consideradas importantes, o grau de constrição e o número de fileiras de células derivadas da primeira célula axial do eixo principal, a morfologia, número e distribuição dos rizoides, o tipo de ramo, endógeno ou adventício, e a morfologia dos entrenós (Krayesky et al. 2012).

Espécies de Caloglossa possuem uma alta plasticidade fenotípica formando complexo de espécies, como o complexo C. leprieurii (Krayesky et al. 2011) ou 
apresentando diversidade críptica, como recentemente revelada para Caloglossa ogasawaraensis por Kamiya \& West (2014).

Caloglossa apomeiotica foi descrita por West \& Zuccarello in West et al. (1994) a partir de material previamente identificado como C. leprieurii do Pacífico mexicano, com base primariamente na reprodução assexual apresentada por essa espécie. Mais tarde, a espécie foi reduzida a um sinônimo de $C$. leprieurii sensu stricto por Kamiya et al. (2003) devido a filogenia molecular obtida com o gene 26S rRNA que demonstrou que a assexualização surgiu mais de uma vez na linhagem de $C$. leprieurii. Portanto, os autores argumentaram que essas espécies não poderiam ser distinguidas com base em seus dados moleculares ou mesmo morfológicos. Krayesky et al. (2011), estudando o complexo C. leprieurii das Américas, restabeleceram $C$. apomeiotica como uma espécie distinta com base em dados moleculares ( $r b c \mathrm{~L}$ e LSU) e morfológicos, sendo considerados diagnósticos para a separação das espécies, o número de fileiras de células derivadas da primeira célula axial do eixo principal (2-5 em $C$. apomeiotica e 3-7 em C. leprieurii) e a largura das lâminas (C. apomeiotica é um pouco mais robusta $[0,9$ a 2,5 mm] do que $C$. leprieurii [0,5 a 1,4 mm]). Entretanto, essas características se sobrepõem e não são efetivas para distinção das espécies.

West et al. (1994) mostraram que $C$. apomeiotica difere de $C$. leprieurii pelo desenvolvimento de bisporângios, enquanto tetrasporângios são menos comuns. Apenas bísporos eram capazes de germinar e gerar novos esporófitos em cultura. Posteriormente, um isolado de C. apomeiotica cultivado por J. A. West (3376) foi descoberto se reproduzindo também sexualmente e foi sequenciado por Krayesky et al. (2011). Essa amostra se posicionou dentro do clado de $C$. apomeiotica. Segundo Krayesky et al. (2011) é possível que $C$. apomeiotica responda a sinais ambientais que permitam que um esporófito produza bisporângios ou tetrasporângios viáveis sob certas condições.

Bisporângios foram frequentemente encontrados no nosso material (Fig. 19A-D) de C. apomeiotica, enquanto tetrasporângios foram muito raros (Fig. 19D). Este caráter reprodutivo foi essencial para separar morfologicamente as espécies. Além da presença de bisporângios, a identificação da espécie pôde ser confirmada pelo gene $r b c$. A baixa divergência encontrada $(0,4 \%)$ entre a nossa sequência de $C$. apomeiotica e a da localidade tipo (HM775456) confirmou que ambas são a mesma 
espécie. Além disso, nossa sequência divergiu em apenas $0,01 \%$ da sequência do Rio de Janeiro (HM775459), que constituiu a primeira citação de $C$. apomeiotica para o Brasil (Krayesky et al. 2011). Devido à semelhança vegetativa entre $C$. apomeiotica e $C$. leprieurii é possível que muitas citações de $C$. leprieurii para o Brasil sejam erros de identificação e correspondam a $C$. apomeiotica, principalmente se esporófitos não forem encontrados para análise. Assim, a abordagem molecular é cada vez mais necessária para a identificação e definição destas espécies. llustrações $C$. leprieurii estão em Kano et al. (2016, submetido, Apêncide B).

Caloglossa confusa foi previamente referida para o Brasil com base em espécimes coletados na llha do Cardoso, São Paulo (Krayesky et al. 2012). Os espécimes recém-coletados $C$. confusa estão de acordo com os estudados por Krayesky et al. (2012), compartilhando caracteres morfológicos, como o número de fileiras de células derivadas da primeira célula axial do eixo principal (1-2), o número de fileiras de células do ramo lateral oposto (1-3), além do tipo de distribuição dos rizoides (tipo $G$ ) e da forte constrição nodal. A distribuição dos rizoides tipo $G$ estabelecida por Kamiya et al. (2003) é caracterizada pelo desenvolvimento de rizoides a partir da primeira e da segunda fileiras de células nos eixos principais e laterais. Além das características morfológicas, a análise molecular com o rbcL mostrou baixa divergência intraespecífica $(0,5 \%$ a $1,3 \%)$ entre nossas amostras e a da localidade tipo (EUA, HM 845517), que está na faixa de variação intraespecífica verificada por Krayesky et al. (2012) (0,4\% -1,5\%), para espécies de Caloglossa. A Figura 20A-D mostra C. confusa encontrada na área estudada.

Dentre as espécies de Caloglossa encontradas no Brasil, C. ogasawaraensis é a mais facilmente identificada devido ao aspecto filamentoso do seu talo e a sua pouca plasticidade morfológica (Fig. 21A-C). Esta espécie tem distribuição mundial ocorrendo em ambientes marinhos e de água doce em ambos os hemisférios (Kamiya \& West 2014). Esses autores demonstraram por meio de dados moleculares combinados ( $r b c \mathrm{~L}$, espaçador $r b c \mathrm{~L}-\mathrm{S}$, LSU e região espaçadora do $c o x$ ) que $C$. ogasawaraensis possui diversidade críptica tendo sido dividida em três grupos filogenéticos com ampla faixa de distribuição geográfica, sugerindo um processo de especiação desses três grupos filogenéticos. De acordo com Kamiya \& West (2014), 
a ampla distribuição geográfica e a próxima similaridade genética dentro de cada um dos três grupos indicam ocorrências ocasionais de evento de dispersão a longa distância nesta espécie.

A divergência intraespecífica máxima dos espécimes brasileiros foi de 0,07\% para o rbcL, confirmando que todos pertencem ao mesmo grupo de $C$. ogasawaraensis do Brasil (JN845521), previamente analisado por Kamiya \& West (2014), e que incluiu amostras do leste do Pacífico-Atlântico e da Malásia. A despeito dos resultados obtidos para C. ogasawaraensis, Kamiya \& West (2014) argumentaram que mais características são necessárias para descrever os grupos filogenéticos como espécies distintas.

Caloglossa rotundata não foi encontrada na área de estudo e descrição e ilustrações detalhadas dessa espécie são fornecidas por Kano et al. (2016, submetido).
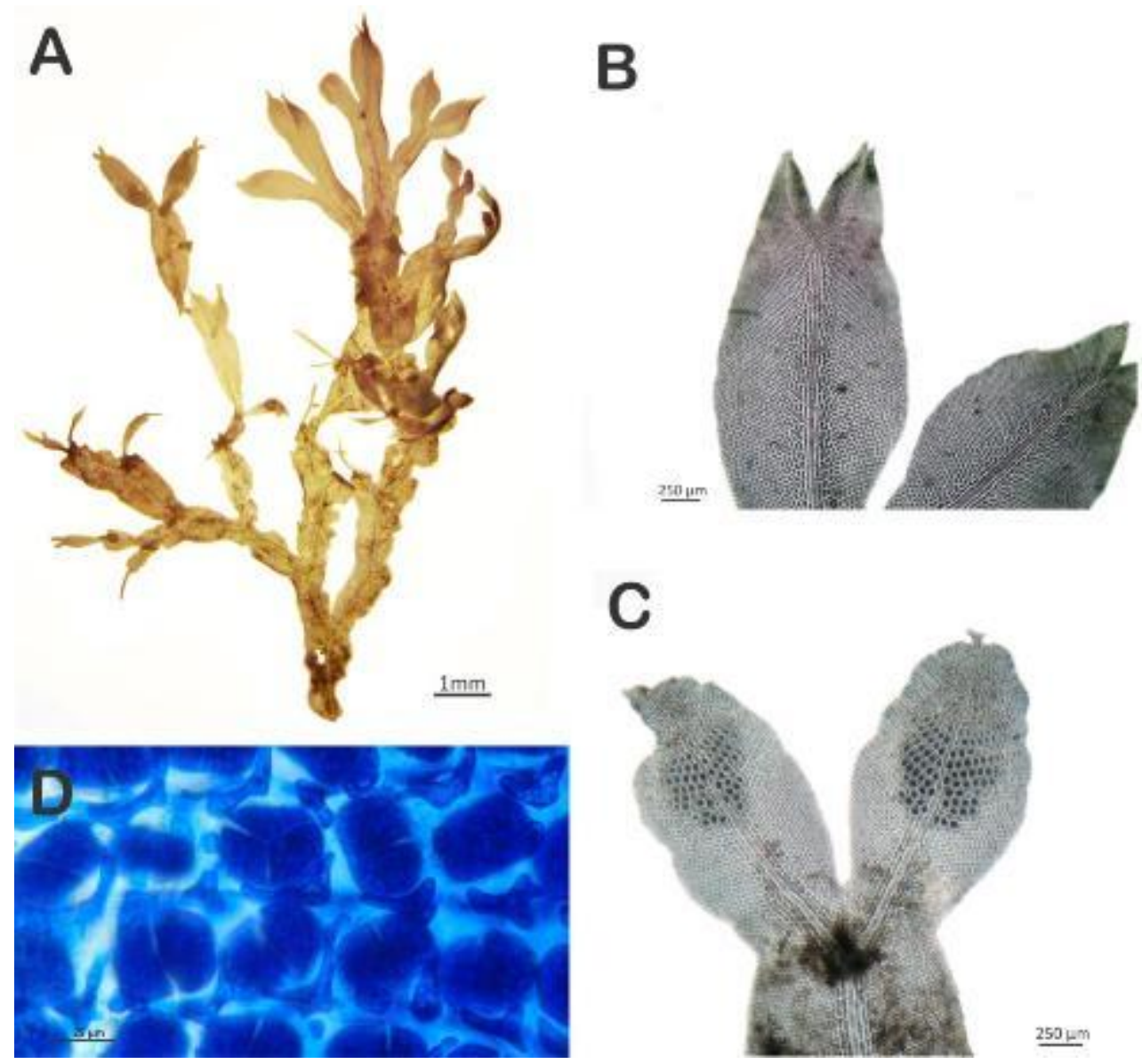

Figura 19 - Caloglossa apomeiotica. A- Aspecto geral do talo. B- Detalhe do padrão de ramificação. C- Detalhe ápice fértil. D- Detalhe dos bisporângios (vista superficial corada com azul de anilina $1 \%$ acidificada com $\mathrm{HCl} 1 \mathrm{~N}$ ). Note tetrasporângio em meio aos bisporângios. 

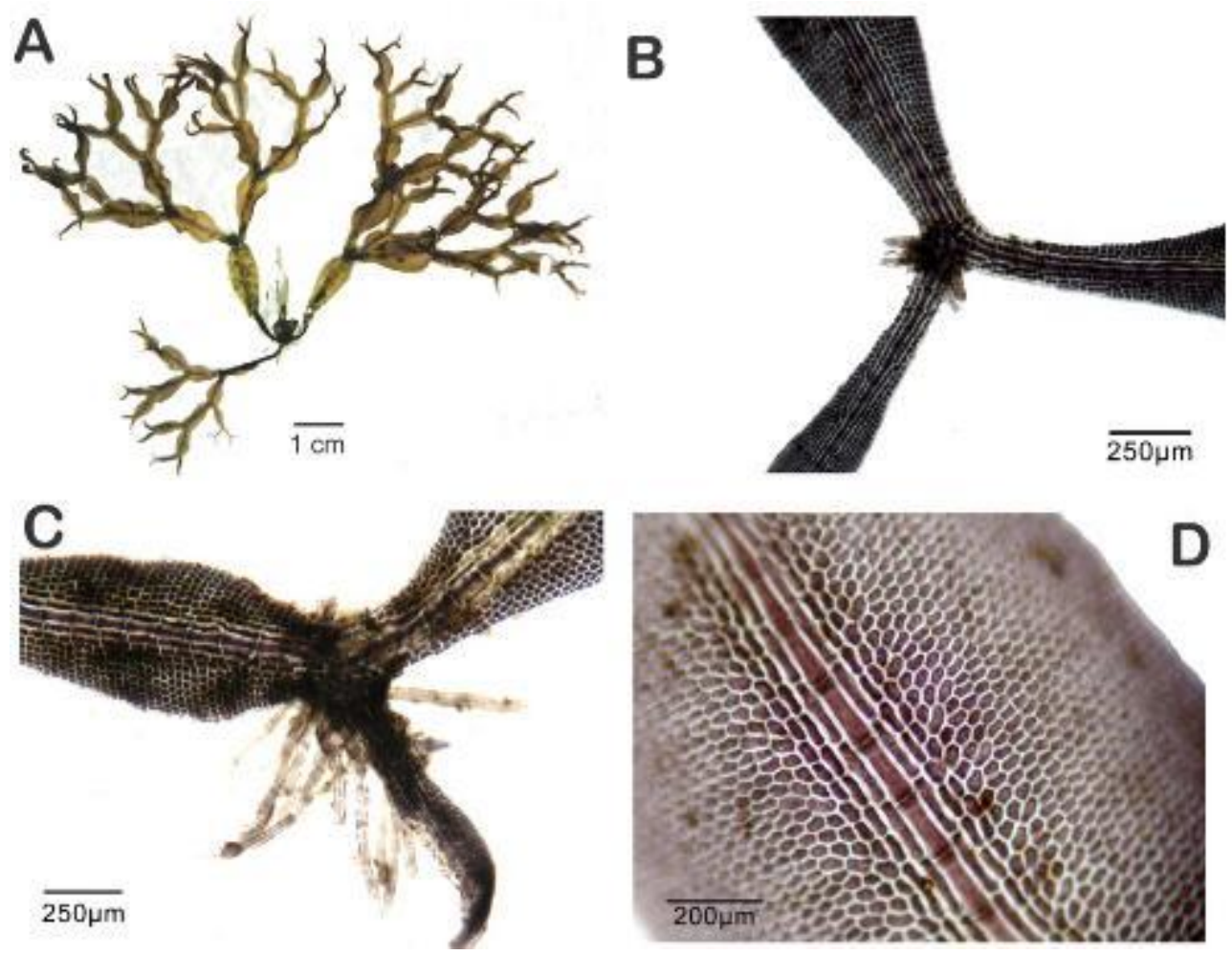

Figura 20 - Caloglossa confusa. A- Aspecto geral do talo. B- Detalhe da constrição. C- Detalhe da constrição com rizoides. D- Detalhe da fronde mostrado nervura central.

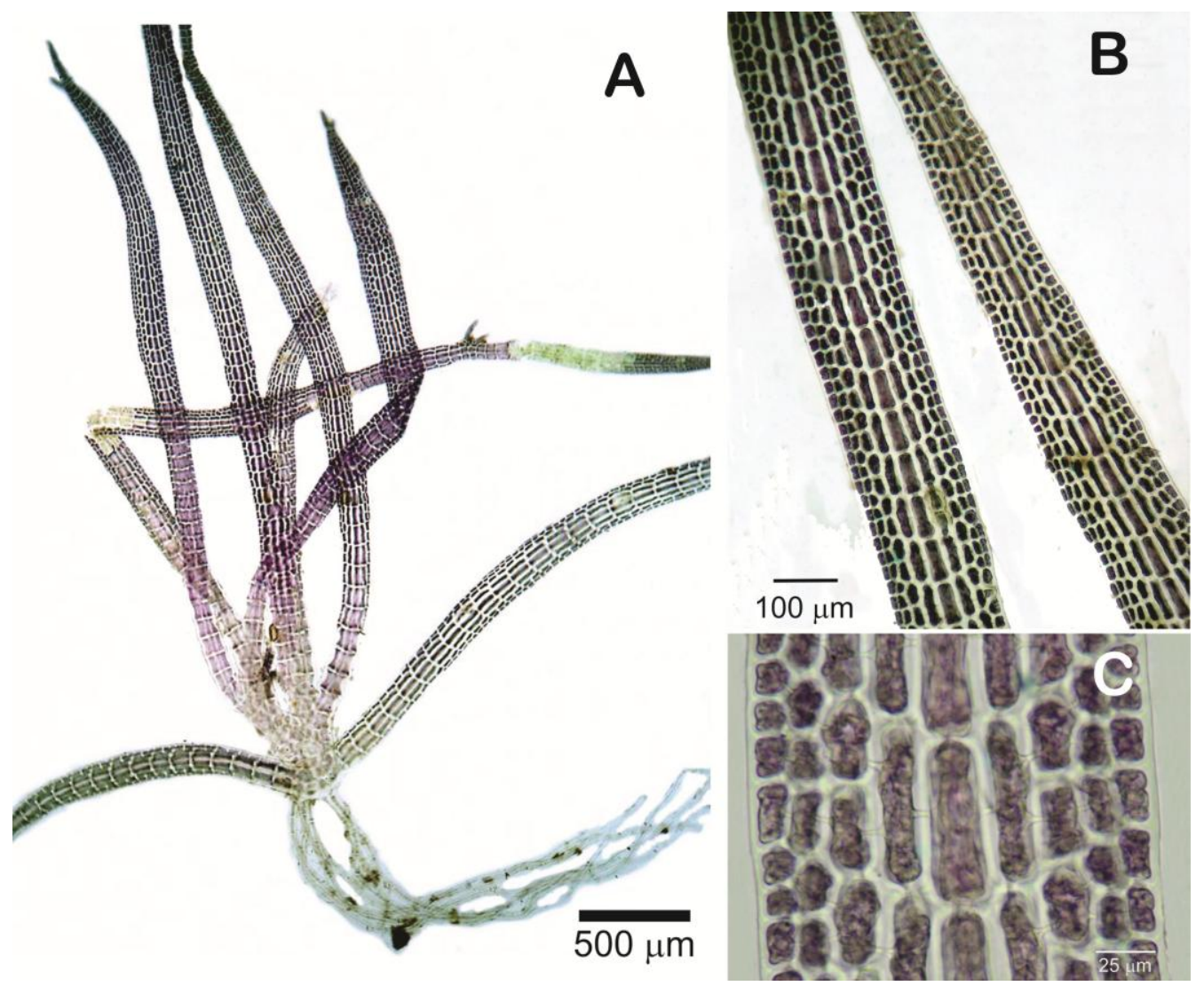

Figura 21 - Caloglossa ogasawaraensis. A- Aspecto geral do talo. B- Detalhe filamento delgado. C- Detalhe da fronde. 


\subsubsection{Gênero Catenella Greville}

Para a análise com o UPA foram geradas quatro sequências de $C$. caespitosa. Não há sequências desse marcador disponíveis para comparação nos bancos de dados. Foi gerada uma matriz com um alinhamento final de 369 pb usando-se uma sequência do GenBank, que apresentou maior similaridade com as nossas sequências, denominada de Rhodymeniales sp. (Sherwood et al. 2010). Nossas amostras de C. caespitosa são 100\% idênticas para esse marcador (Fig. 22).

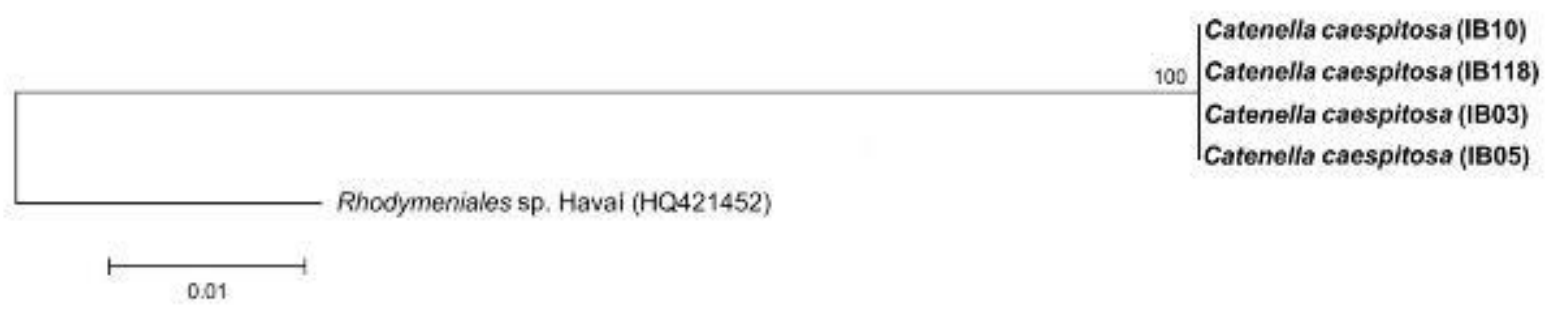

Figura 22 - Árvore de Neighbor-Joining (NJ) para as sequências do marcador UPA para o gênero Catenella. O valor de bootstrap (2000 réplicas) está representado no ramo. As sequências obtidas neste estudo estão representadas em negrito na árvore e a retirada do Genbank está seguida do local de coleta e do número de acesso.

Uma única sequência de C. caespitosa (IB05) foi obtida para o COI-5P, entretanto não há sequências desse marcador disponíveis nos bancos de dados para comparação. Apenas cinco sequências do gênero Catenella estão disponíveis no GenBank, sendo duas do marcador SSU rDNA, duas do cox2 e uma do espaçador rbcL-S. Não há nenhuma sequência do gênero disponibilizada no BOLD http://www.barcodinglife.org). Devido à falta de sequências nos bancos de dados de marcadores do tipo "DNA Barcode" e do rbcL, foram geradas sequências do SSU para as nossas amostras visando comparar com as disponibilizadas no GenBank.

A matriz de SSU foi gerada com seis sequências, sendo três sequências parciais obtidas nesse estudo e três do GenBank, com Caulacanthus okamurae Yamada (AY437663) usada como grupo externo. O alinhamento final foi de 533 pb. A Figura 23 mostra a árvore de NJ gerada para o SSU. Nossas amostras não apresentaram divergência intraespecífica, sendo 100\% idênticas. As sequências do banco de dados, ambas de Saunders et al. (2004), C. caespitosa (AY437661) e C. nipae Zanardini (AY437662) divergiram em apenas 0,018\% (1 pb) em 1791 posições. Nossas 
amostras divergiram dessas últimas de 2,8\% (15 pb) a 3,0\% (16 pb) em 533 posições, indicando que se trata de táxons distintos.

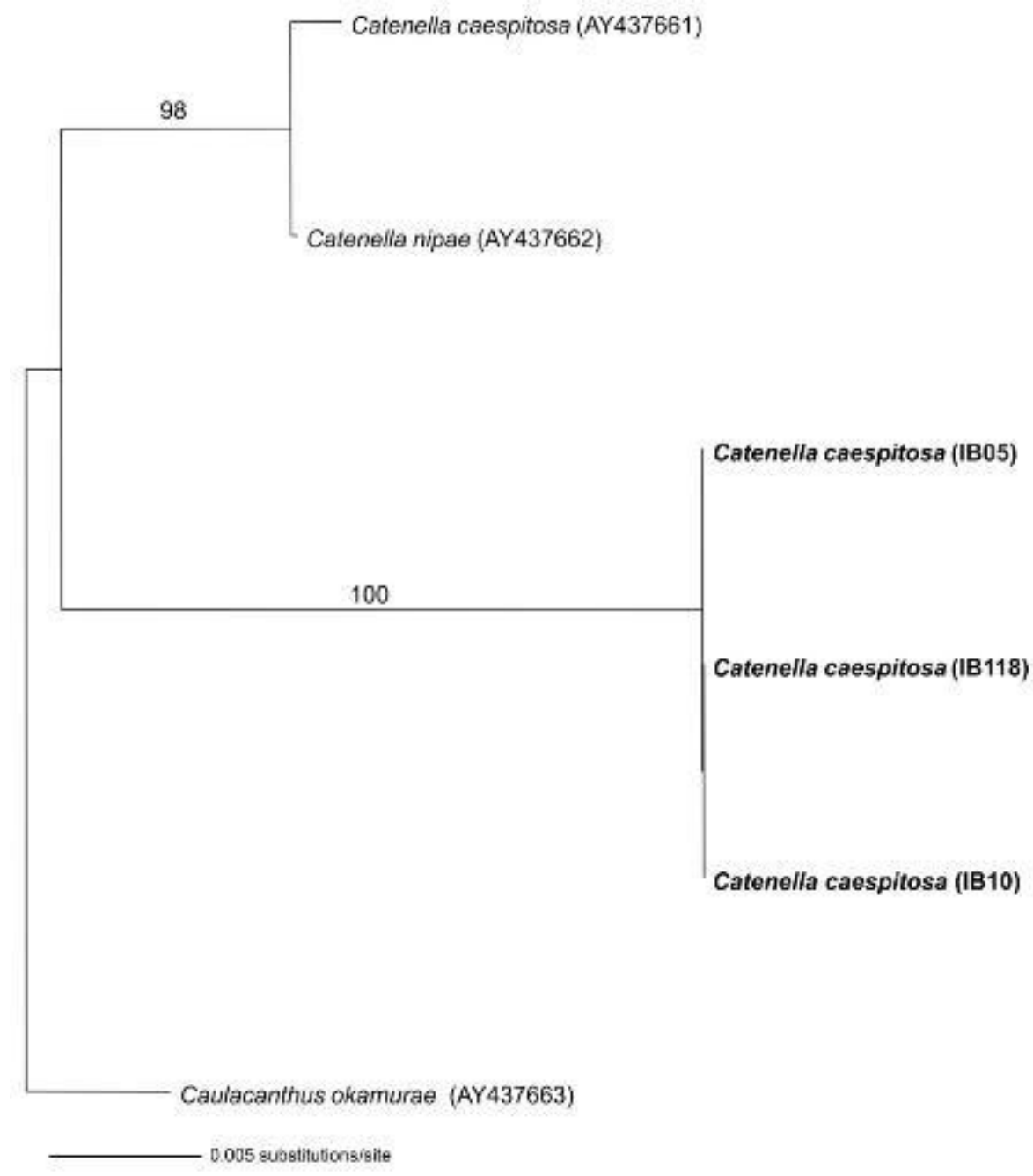

Figura 23 - Árvore de Neighbor-Joining (NJ) para as sequências do marcador SSU para o gênero Catenella. Apenas valores de bootstrap maiores que 70\% (2000 réplicas) estão representados nos ramos. As sequências obtidas neste estudo estão representadas em negrito na árvore e as retiradas no Genbank estão seguidas do local de coleta e do número de acesso.

O gênero Catenella, comum em regiões tropicais e subtropicais do mundo e conspícuo em flora de manguezais, inclui 12 espécies e categorias infraespecíficas, das quais seis são aceitas taxonomicamente (M.D. Guiry in Guiry \& Guiry 2016).

Catenella é de fácil reconhecimento por seu talo essencialmente rastejante, regularmente constricto com segmentos cilíndricos ou comprimidos, fusiformes ou ovais, com ramificação dicotômica ou tricotômica nas constricções (Taylor 1960, Joly 1965) (Fig. 24). 
Duas espécies são referidas para o litoral brasileiro: $C$. caespitosa [como $C$. repens (Lightfoot) Batters (Joly 1957, 1965)], distribuída do Paraná ao Maranhão (Oliveira-Carvalho \& Pereira 2016), e C. impudica (Montagne) J. Agardh com ocorrência restrita a Santa Catarina e São Paulo (Oliveira Filho 1977, OliveiraCarvalho \& Pereira 2016). Catenella impudica foi citada por Möbius (1889) para Santa Catarina e por Luederwaldt (1919) para São Paulo, sendo compilada na obra de Taylor (1960). Essa espécie nunca mais foi citada para o litoral brasileiro e, de acordo com Oliveira Filho (1977), C. impudica é rara e muito próxima de C. caespitosa (como $C$. repens) necessitando de estudos mais detalhados. De acordo com Cutrim (1998), as citações de C. impudica de Luederwaldt (1919) para os manguezais de São Paulo e de Santos correspondem a C. caespitosa, embora Cutrim (1998) não tenha justificado esta afirmação.

As espécies são separadas pela estrutura de fixação do talo, cujos haptera em C. impudica são formados a partir de segmentos terminais alongados projetados na axila das dicotomias, enquanto em $C$. caespitosa os haptera são formados como protuberâncias flagelares a partir de pontos de ramificação, mas não como segmentos regulares do ramo (Taylor 1960).

Nossos resultados moleculares como o SSU sugerem que a citação de $C$. caespitosa para o Brasil pode estar equivocada. Entretanto, esses resultados são ainda muito preliminares para qualquer afirmação conclusiva. Das seis espécies aceitas taxonomicamente, apenas duas foram sequenciadas ( $C$. caespitosa e $C$. nipae), porém para nenhum marcador do tipo "DNA Barcode" e não há sequências da localidade tipo para comparação (Side Rocks, Anglesey, Wales, UK). O gênero necessita de investigações mais aprofundadas tanto moleculares quanto morfológicas para esclarecer sua diversidade específica. 


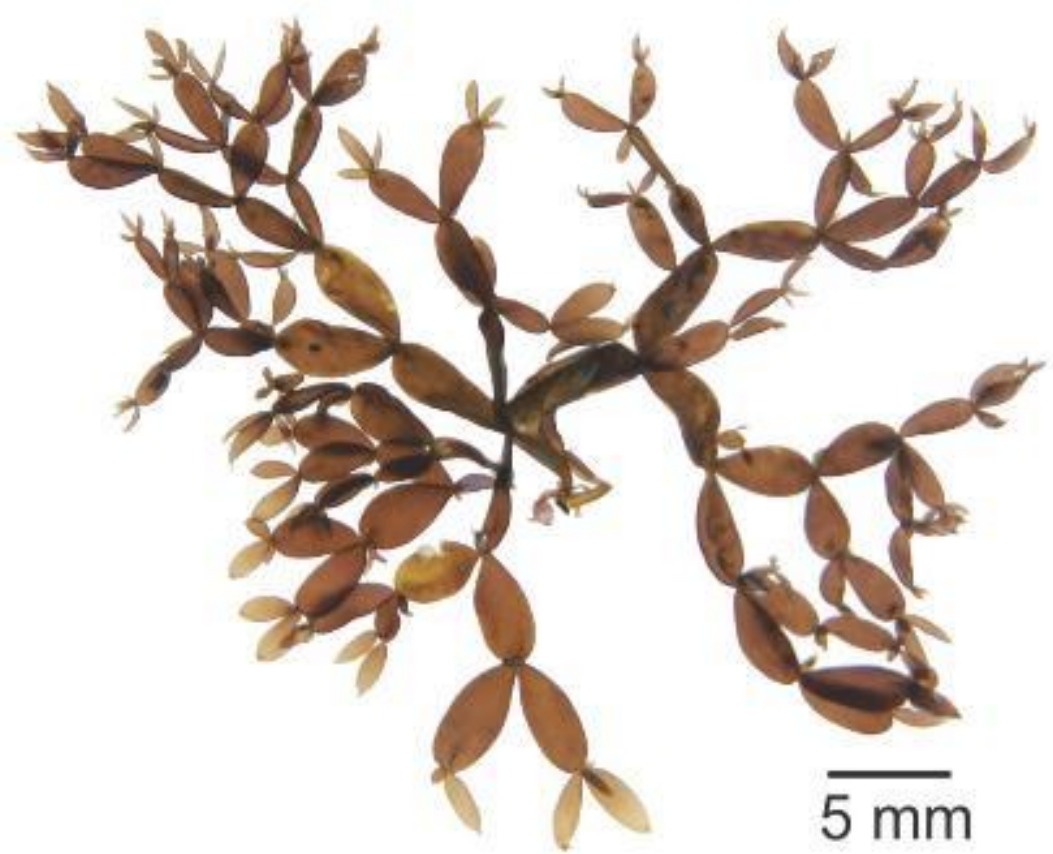

Figura 24 - Catenella caespitosa. Aspecto geral do talo. Note segmentos ovais e achatados com constriç̧ões bem evidentes e ramificação dicotômica ou tricotômica.

\subsection{Chlorophyta}

\subsubsection{Gênero Boodleopsis Gepp \& E.S. Gepp}

A análise molecular com o gênero Boodleopsis foi feita a partir de duas sequências parciais do gene $r b c L$ para a espécie $B$. vaucherioidea. Não foi possível obter sequências para $B$. pusilla. Além do $r b c \mathrm{~L}$, tentativas de sequenciamento com os todos os demais marcadores utilizados neste estudo falharam para as duas espécies. Apenas uma sequência parcial de rbcL de Boodleopsis está depositada no banco de dados para comparação, B. pusilla, procedente de Cockroach Bay, Flórida, EUA (DQ469320).

Foi gerada uma matriz com quatro sequências, duas de $B$. vaucherioidea obtidas neste trabalho e duas do GenBank, B. pusilla e Halimeda copiosa Goreau \& E.A. Graham (FJ624508), usada como grupo externo. O alinhamento final consistiu em 598 pb. A árvore de NJ é mostrada na Fig. 25. As sequências de $B$. vaucherioidea são idênticas e divergiram de B. pusilla da Flórida em 0,5\% (3 pb). 
O gênero Boodleopsis, com distribuição tropical a subtropical, inclui nove espécies, todas aceitas taxonomicamente (M.D. Guiry in Guiry \& Guiry 2016). Espécies de Boodleopsis são encontradas em manguezais e em costões rochosos (Taylor et al. 1953), crescendo desde o supralitoral até o infralitoral (Calderón-Sáenz \& Schnetter 1989, Littler \& Littler 2000).

Boodleopsis pusilla, descrita originalmente como Dichotomosiphon pusillus F.S. Collins, foi citada pela primeira vez para o Brasil crescendo sobre pnematóforos de Avicennia na Baía de Guaratuba, Paraná, por Taylor et al. (1953), que providenciaram a nova combinação para o gênero Boodleopsis. A espécie possui ampla distribuição litoral brasileiro, se estendendo de Santa Catarina (Hadlich 1984) ao Amapá (Paula et al. 1989). Boodleopsis pusilla é comumente encontrada em manguezais formando tufos emaranhados sobre pneumatóforos ou fundos lodosos (Joly 1965) e também em costões rochosos de baías calmas (Taylor et al. 1953).

Boodleopsis pusilla é caracterizada por seus filamentos cenocíticos ramificados de forma dicotômica (raramente tricotômica, irregular ou verticilada) com constricções regulares profundas a rasas nas dicotomias, vestigiais ao longo do talo, e dicotomias em ângulo agudo, 60-80 (Taylor et al. 1953, Joly 1965, Yoneshigue-Braga 1970, Kanawaga 1984, Calderón-Sáenz \& Schnetter 1989, Barata 2004, Coto \& Pupo 2009, Almeida 2013). 
Figura 25 - Árvore de Neighbor-Joining (NJ) para as sequências do marcador $r b c \mathrm{~L}$ para o gênero Boodleopsis. As sequências obtidas neste estudo estão representadas em negrito na árvore e as sequências retiradas do GenBank estão seguidas do local de coleta, quando disponível, e do número de acesso.

Boodleopsis vaucherioidea foi descrita originalmente para a Colômbia (Caribe) por Calderón-Sáenz \& Schnetter (1989). A espécie foi citada pela primeira vez para o Brasil crescendo em costões rochosos da Baía da llha Grande, Rio de Janeiro, por Cassano et al. (2004). A espécie é distinta de B. pusilla pela sua ramificação divaricada em ângulo de $90^{\circ}-140^{\circ}$, raramente menor, sem contrições nas dicotomias (Cassano et al. 2004). Características secundárias para a separação desta espécie 
de B. pusilla incluem: o maior diâmetro dos filamentos eretos, núcleos menores, cloroplastos normalmente discoides com dois grãos de amido em $B$. vaucherioidea (Calderón-Sáenz \& Schnetter 1989). Entretanto, Cassano et al. (2004) verificaram sobreposição do diâmetro dos filamentos, variação na forma dos cloroplastos $e$ número de grãos de amido entre $B$. vaucherioidea e $B$. pusilla descritas por diferentes autores. No presente estudo, nossos espécimes de $B$. vaucherioidea mostraram menor diâmetro dos filamentos eretos (15,7-29 $\mu \mathrm{m}$ de diâmetro vs. 21,5-36 $\mu \mathrm{m}$ de diâmetro em B. pusilla), embora haja sobreposição deste caráter nas duas espécies estudadas. Espécimes de B. vaucherioidea foram cultivados por Cassano et al. (2004) e as características diagnósticas da espécie foram mantidas em cultura, i.e., contrições ausentes nas dicotomias e râmulos divaricados. As autoras salientaram a possibilidade de $B$. vaucherioidea ter sido identificada erroneamente como $B$. pusilla para outras localidades do Brasil e recomendaram a reavaliação das citações $B$. pusilla para o litoral brasileiro.

Morfologicamente, os espécimes de B. pusilla (Fig. 26A-C) e B. vaucherioidea (Fig. 27A-C) da llha Barnabé foram facilmente identificados, especialmente por se encaixaram nas características diagnósticas de valor taxonômico usadas para a separação das espécies, como o ângulo dos râmulos e a presença ou ausência de constriç̧ões nas dicotomias. Em contrapartida, nossos resultados moleculares não são conclusivos, já que amostras de B. pusilla não puderam ser sequenciadas, mesmo após várias tentativas, para comparação com as sequências de $B$. vaucherioidea. $A$ única sequência parcial de $r b c L$ de $B$. pusilla do GenBank, proveniente da Flórida, região próxima as localidades-tipo, Jamaica e Bermuda (Leliaert et al. 2001), mostrou baixa divergência genética $(0,5 \%)$ com nossas amostras de $B$. vaucherioidea. $O$ esclarecimento dessas entidades taxonômicas depende de uma maior amostragem $\mathrm{e}$ sequenciamento completo do $r b c \mathrm{~L}$ e de outros marcadores moleculares. Há possibilidade dos caracteres considerados de valor taxonômico corresponderam a plasticidade fenotípica, e, portanto, a coespecificidade desses táxons não pode ser desconsiderada. 

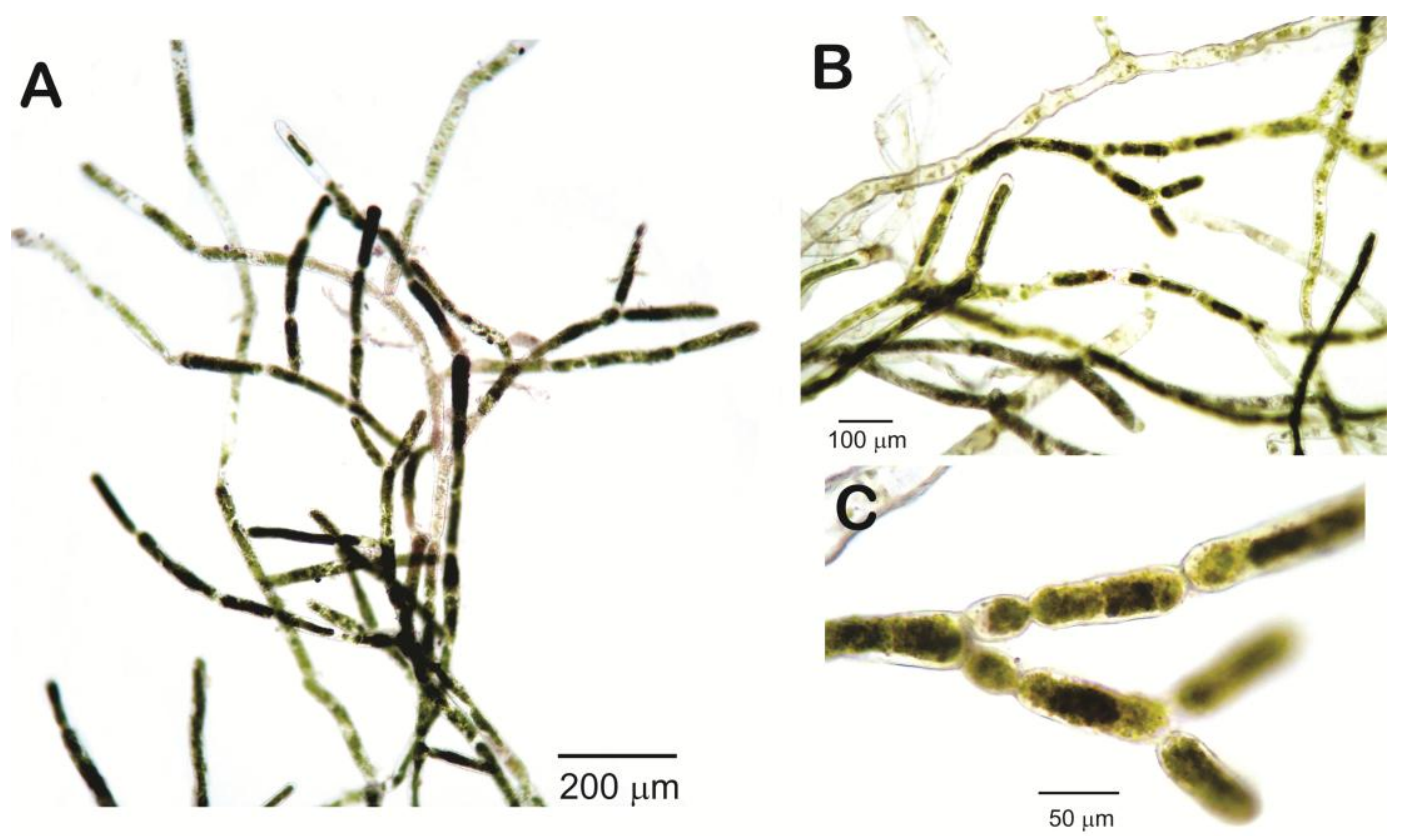

Figura 26 - Boodleopsis pusilla. A- Aspecto geral do talo. B- Detalhe do padrão de ramificação dicotômico. CDetalhe das constricções nas dicotomias e ao longo do filamento.

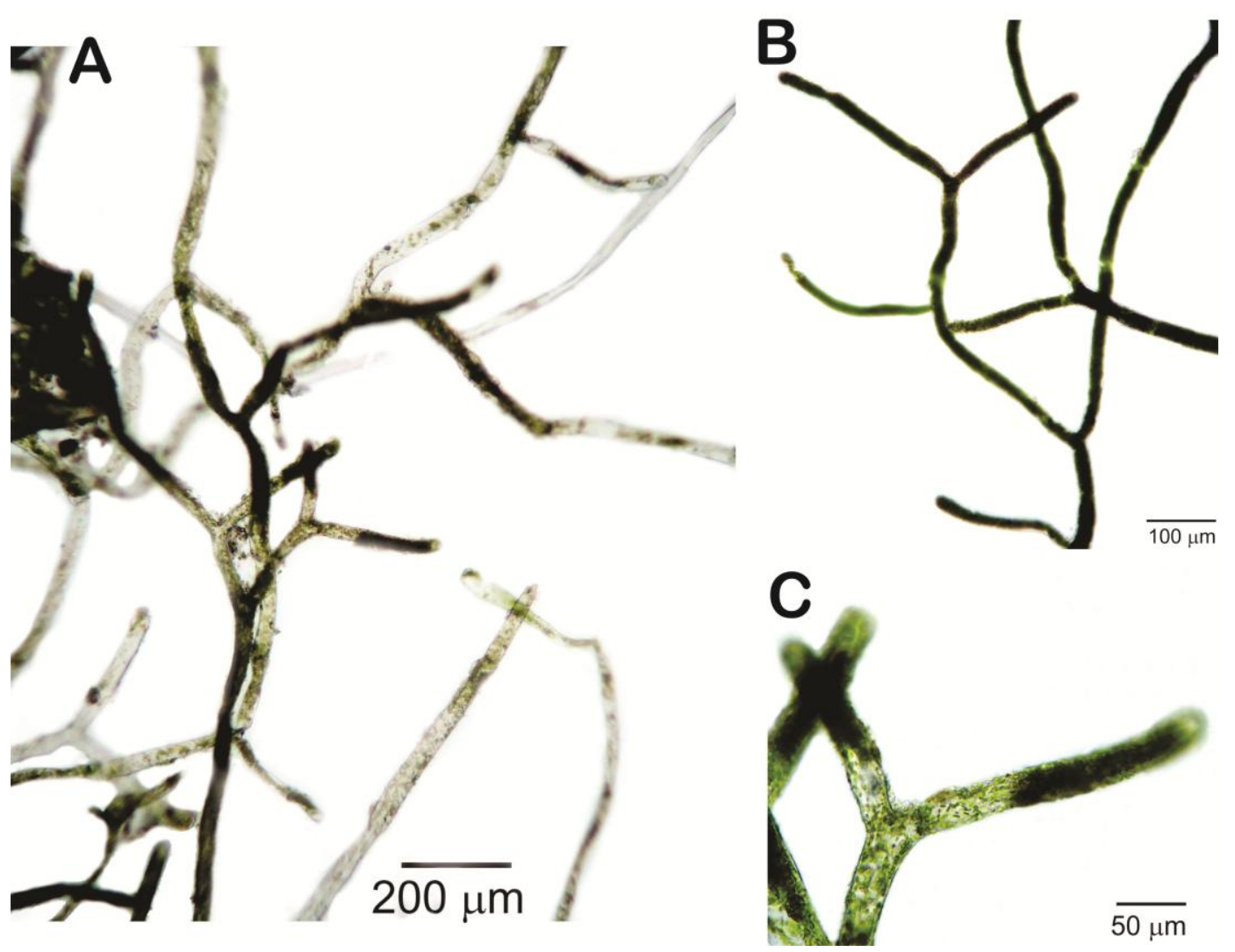

Figura 27 - Boodleopsis vaucherioidea. A- Aspecto geral do talo. B- Detalhe da ramificação dicotômica divaricada. C- Detalhe dos râmulos sem constriç̧ão nas dicotomias. 


\subsubsection{Gênero Cladophoropsis Børgesen}

A análise molecular do gênero Cladophoropsis foi baseada em sequências do marcador ITS rDNA nuclear (ITS 1, ITS 2 e 5.8S), uma vez que as numerosas tentativas de amplificação do marcador $r b c L$ e dos marcadores do tipo "DNA Barcode", incluindo o tufA, eleito "DNA Barcode" padrão para algas verdes, falharam. Além disso, a disponibilidade de inúmeras sequências de ITS rDNA nuclear para a família Boodleaceae no banco de dados viabilizou uma ampla comparação entre as sequências. A árvore de NJ (Fig. 28) foi construída com 31 sequências, duas geradas neste trabalho e 29 provenientes do GenBank, com Cladophora wrightiana Harvey (KF595077) usada como grupo externo. O alinhamento final consistiu em 1325 pb. O ITS rDNA nuclear é um marcador altamente variável e, portanto, muitas regiões de alinhamento são instáveis. No entanto, na análise gerada os agrupamentos correspondentes aos gêneros e espécies são claramente observáveis.

As nossas amostras de C. membranacea, 100\% idênticas (IB96 e IB100), se posicionaram em um ramo isolado e não são relacionadas a nenhuma sequência de ITS rDNA nuclear disponível nos bancos de dados. O clado de $C$. membranacea do GenBank, que agrupou amostras da localidade tipo (Saint Croix, Ilhas Virgens, EUA), do Panamá e do México, com suporte moderado (85\%), se posicionou molecularmente distante das amostras brasileiras. Uma análise de NJ com uma maior amostragem (218 sequências), inclusive com sequências inéditas de Boodleaceae disponibilizadas gentilmente por Frederik Leliaert (Universidade de Ghent, Bélgica) corrobora que as amostras brasileiras de C. membranacea são distintas de qualquer espécie ou mesmo gênero da família Boodleaceae (Fig. 29). Espécimes com morfologia $C$. membranacea estão espalhados em sete clados distintos, nomeados por Leliaert et al. (2009) como Boodlea sp. 1, Boodlea sp. 2, Boodlea sp. 4, Boodlea sp. 5, Boodlea sp. 8, Boodlea sp. 12, além do clado de C. membranacea da llha Barnabé, SP. Amostras da localidade tipo estão posicionadas no clado Boodlea sp. 5. 


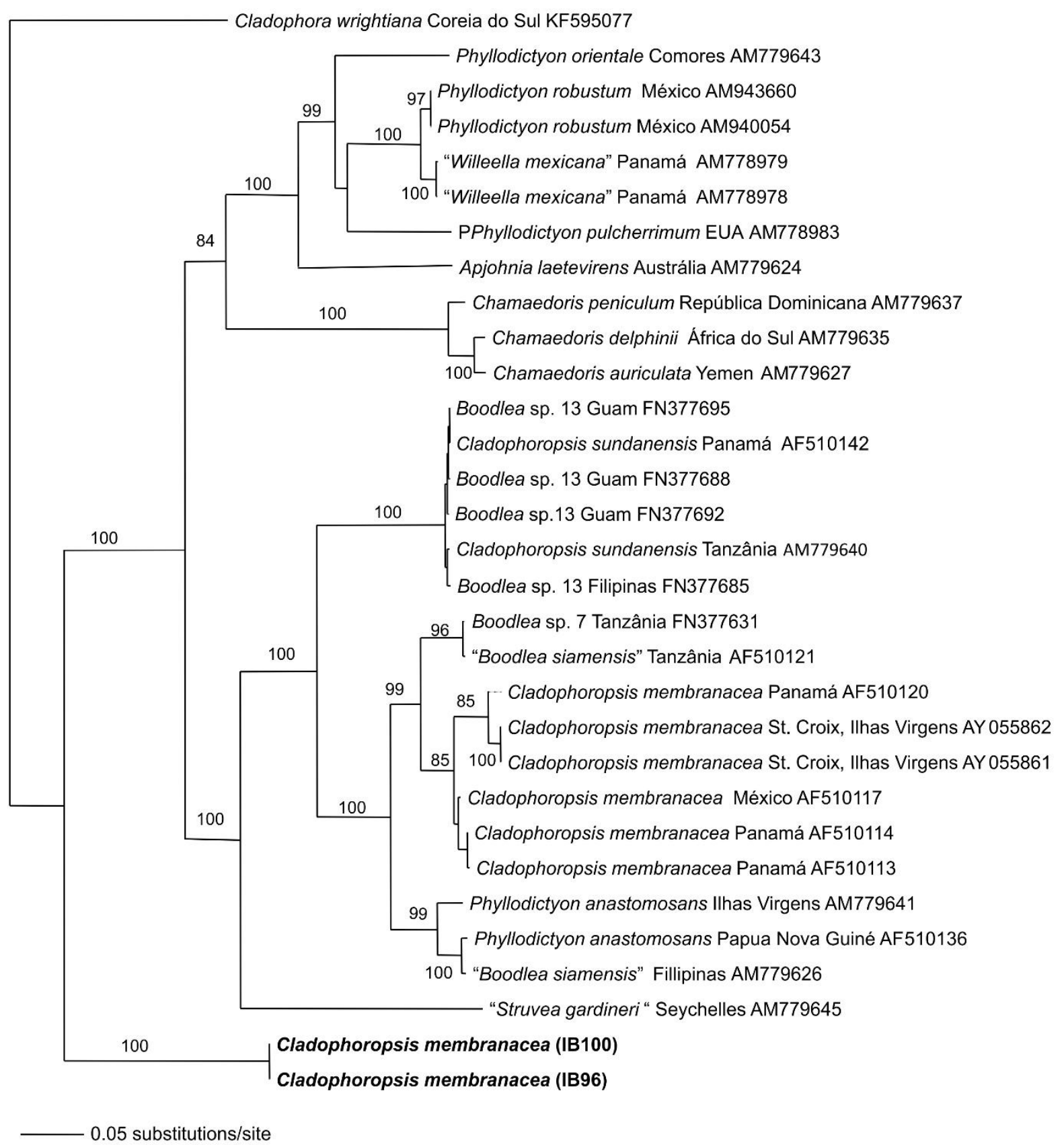

Figura 28 - Árvore de Neighbor-Joining (NJ) para as sequências do marcador ITS rDNA nuclear para o gênero Cladophoropsis. Apenas valores de bootstrap maiores que 70\% (2000 réplicas) estão representados nos ramos. As sequências obtidas neste estudo estão representadas em negrito na árvore. As sequências retiradas do GenBank estão seguidas do local de coleta e do número de acesso. 


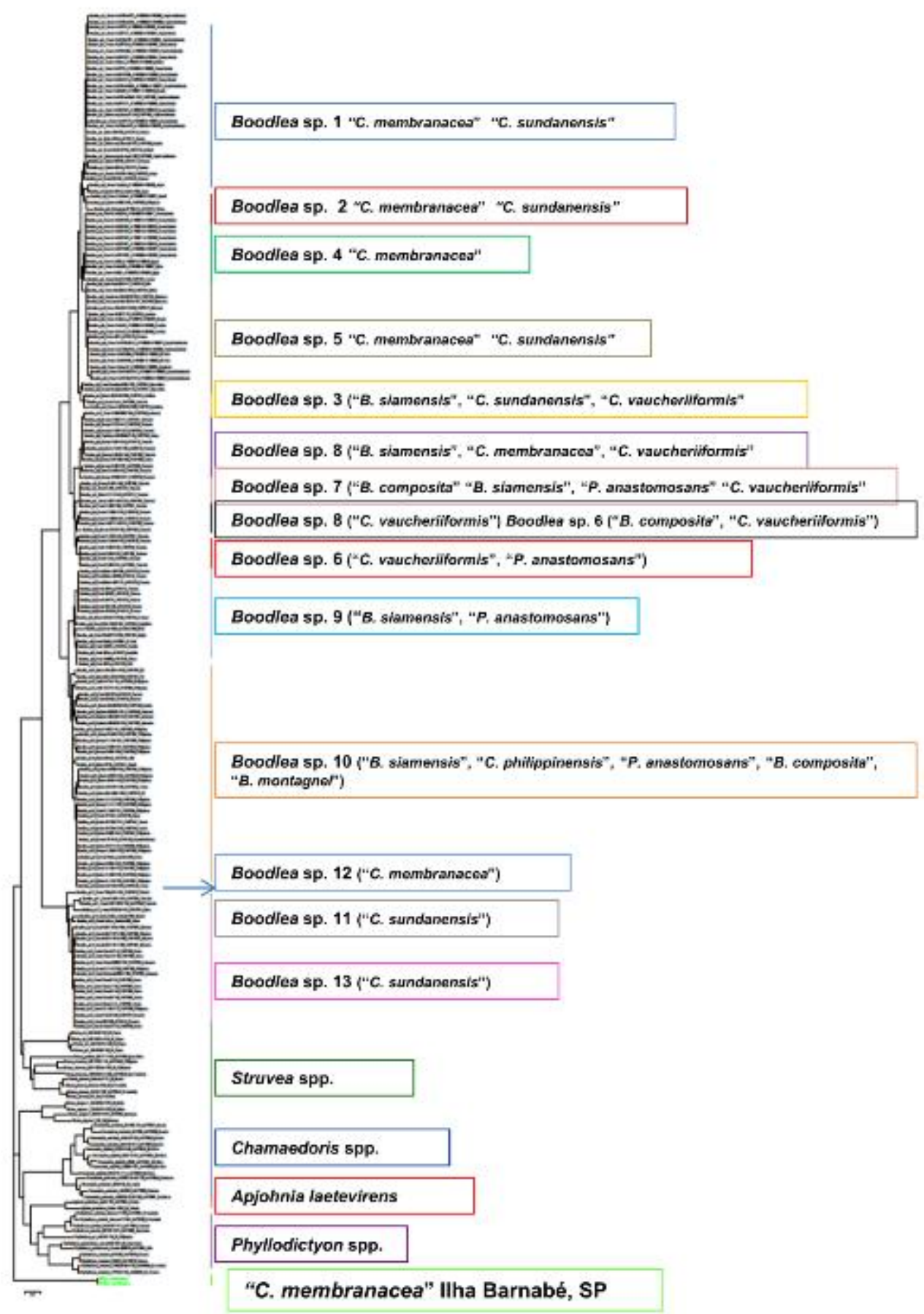

Figura 29 - Árvore de Neighbor-Joining (NJ) para as sequências do marcador ITS rDNA nuclear para o gênero Cladophoropsis. Espécimes com morfologia C. membranacea estão espalhados em sete clados distintos. As sequências obtidas neste estudo estão representadas em verde na árvore. 
O gênero Cladophoropsis abriga 41 espécies e categorias infraespecíficas, das quais 12 são aceitas taxonomicamente (M.D. Guiry in Guiry \& Guiry 2016). Cladophoropsis é caracteristicamente reconhecido pela ausência de septos na base de ramos laterais, pelo menos nos ramos jovens (Joly 1965, Barata 2004, Coto \& Pupo 2009). A espécie Cladophoropsis membranacea foi citada pela primeira vez para 0 Brasil para Pernambuco por Taylor (1931) como Aegagropila membranácea (C.Agardh) Kützing). A espécie possui ampla distribuição no litoral brasileiro, tendo como limite sul o estado de Santa Catarina e como limite norte, o estado do Maranhão (Moura 2016a). É reconhecidamente uma espécie encontrada com frequência em manguezais, mas também em recifes de arenito e costões rochosos com ampla distribuição em águas tropicais e temperadas quentes (Joly 1965, Leliaert \& Coppejans 2006, Alves et al. 2012, Almeida 2013). Cladophoropsis membranacea é próxima morfologicamente de $C$. macromeres W.R. Taylor, uma espécie também citada para o Brasil, porém de ocorrência restrita aos estados de Santa Catarina, Rio de Janeiro, Paraíba e Rio Grande do Norte (Moura 2016a). Cladophoropsis macromeres foi citada pela primeira vez para o litoral do Brasil a partir de material coletado no Rio de Janeiro (Yoneshigue-Valentin \& Amado Filho 1989). Cladophoropsis membranacea pode ser diferenciada de $C$. macromeres pelo diâmetro do filamento principal, até aproximadamente duas vezes maior em $C$. macromeres (280-510 $\mu \mathrm{m}$ de diâmetro vs. 80-310 $\mu \mathrm{m}$ em C. membranacea), pela presença de septos em alguns ramos laterais mais velhos em $C$. membranacea, ausentes em $C$. macromeres e pelo talo formando tapetes soltos, não fixos ao subtrato, ou frouxamente emaranhado a outras macroalgas em C. macromeres (Taylor 1960, Yoneshigue-Valentin \& Amado Filho 1989, Leliaert \& Coppejans 2006, Almeida et al. 2012, Alves et al. 2012).

Morfologicamente, nossos exemplares (Fig. 30A-E) se encaixam perfeitamente em C. membranacea estando de acordo com as descrições fornecidas na literatura quanto às dimensões das células do eixo principal (75-112,5 $\mu \mathrm{m}$ de diâmetro), ausência de septos na base dos ramos (pelo menos nos ramos jovens), ramificação irregular a unilateral, fixação do talo por células tenaculares oriundas de células basais ou rizoides formados em qualquer parte do talo, células tenaculares também originadas de qualquer parte do talo, nas regiões das ramificações, meio e ápice das células e filamentos fortemente entrelaçados por células tenaculares (Taylor 1960, 
Joly 1965, Leliaert \& Coppejans 2006, Coto \& Pupo 2009, Almeida et al. 2012, Alves et al. 2012, Almeida 2013).

Desde o início da década de 1990, Cladophoropsis é reconhecido como um gênero polifilético, com espécies, incluindo a espécie-tipo, C. membranacea, formando um clado com gêneros de "Siphonocladales" (Boodlea G. Murray \& De Toni, Phyllodictyon J.E. Gray, Struveopsis Rhyne \& H. Robinson, Struvea Sonder e Chamaedoris Montagne), enquanto outras espécies de Cladophoropsis formam um clado com espécies de Cladophora Kützing da Seção Longi-articulatae (Kooistra et al. 1993, Leliaert et al. 2003, 2007b, Leliaert \& Coppejans 2006). Uma revisão desses gêneros feita por Leliaert et al. (2009) usando o marcador ITS rDNA nuclear resultou no reconhecimento de 13 espécies filogenéticas, com um conflito considerável entre as definições de espécies tradicionais e filogenéticas, incluindo diversidade críptica com formas morfológicas idênticas distribuídas em diferentes clados e variação morfológica intraespecífica com a maior parte das espécies filogenéticas contendo uma mistura de diferentes morfologias (Fig. 29). Devido à complexidade evolutiva observada pelos autores e as grandes mudanças nomenclaturais necessárias para acomodar os táxons, Leliaert et al. (2009) propuseram considerar todas espécies ou clados dentro de um complexo, chamado de complexo Boodlea, salientando que todos (Cladophoropsis, Boodlea, Phyllodictyon, Struveopsis, Struvea e Chamaedoris) poderiam ser reconhecidos como um único gênero. Além disso, como seria impossível fornecer nomes de táxons para as 13 espécies filogenéticas, por não poderem ser ligadas prontamente a tipos nomenclaturais, os autores mantiveram o gênero Cladophoropsis para fins de estabilidade taxonômica, aguardando evidência molecular adicional.

Cladophoropsis membranacea, assim como C. macromeres do Brasil necessitam de uma revisão, empregando-se uma abordagem molecular a partir de uma ampla amostragem no litoral brasileiro. Uma única sequência de SSU rDNA de C. macromeres está disponível no GenBank, gerada a partir de uma amostra da localidade tipo (Flórida, EUA). Além de uma maior amostragem das nossas espécies, sequências de outros marcadores como o SSU rDNA e o LSU rDNA seriam necessárias para fins comparativos, assim como seriam informativas para esclarecer a posição filogenética de nossos espécimes dentro das Cladophorales. 


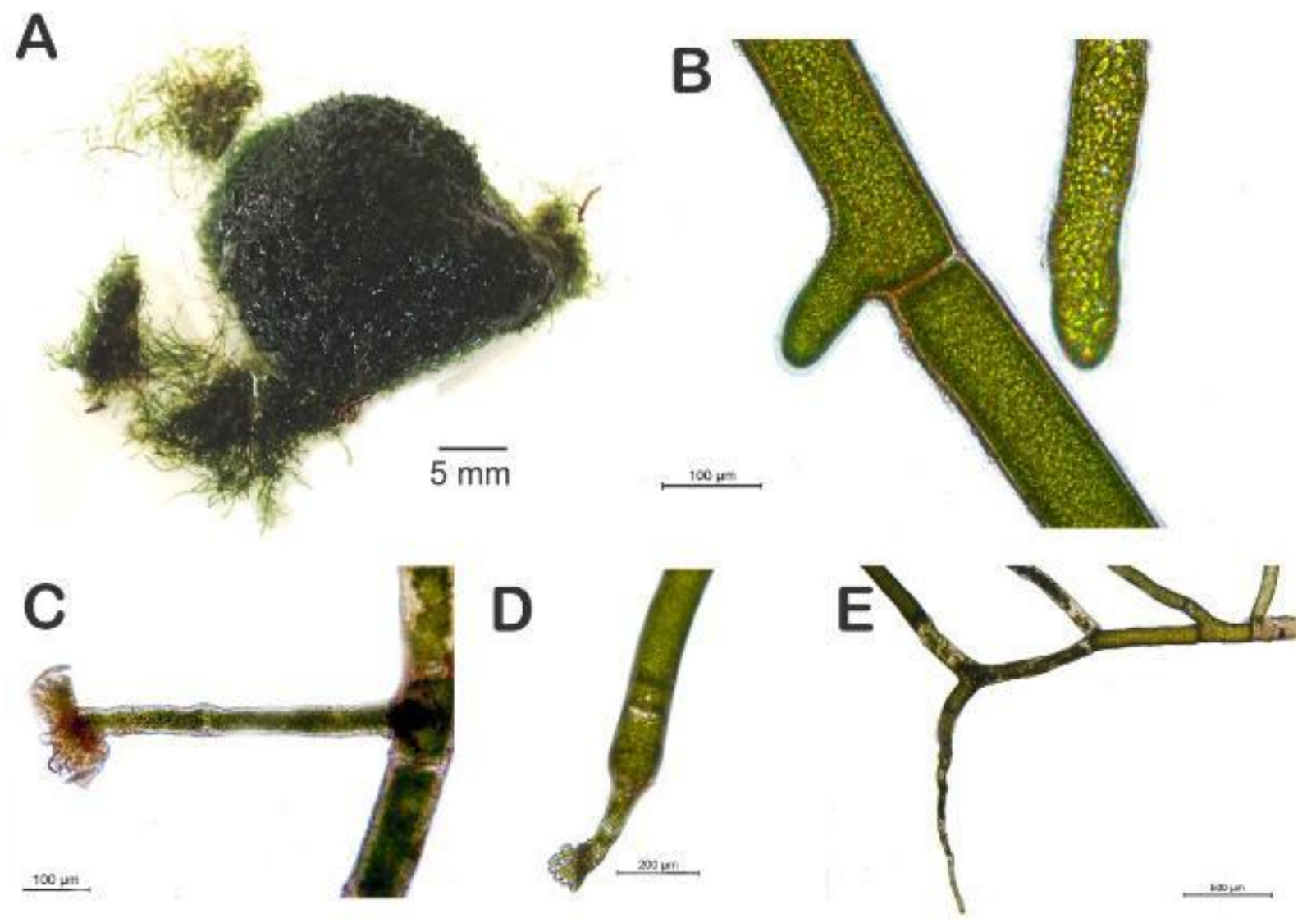

Figura 30 - Cladophoropsis membranacea. A- Aspecto geral do talo mostrando denso tufo. B- Detalhe ramo lateral novo sem septo na base. C- Detalhe de rizoide. D- Detalhe da célula tentacular. E- Detalhe da ramificação unilateral e rizoide.

\subsubsection{Gênero Rhizoclonium Kützing}

As espécies de Rhizoclonium identificadas na llha Barnabé: $R$. africanum Kützing e $R$. riparium (Roth) Kützing foram encontradas em pequenos filamentos emaranhados, principalmente a Bostrychia spp. Poucas sequências parciais de LSU, SSU e ITS2 para espécies desse gênero estão depositadas nos bancos de dados. Como o marcador padrão do tipo "DNA Barcode" para as algas verdes, tufA é ineficiente para Cladophorales, foram feitas inúmeras tentativas de amplificação com os marcadores ITS rDNA nuclear e SSU para ambas espécies, visando a comparação das sequências com as disponíveis no GenBank. Além disso, foram testados todos os marcadores utilizados neste estudo, entretanto, nenhuma tentativa teve sucesso para qualquer marcador. 
O gênero Rhizoclonium é considerado cosmopolita ocorrendo em águas marinhas, dulcícolas e salobras, e abriga 78 espécies e categorias infraespecíficas, das quais 32 são aceitas taxonomicamente (M.D. Guiry in Guiry \& Guiry 2016). Três espécies de Rhizoclonium são referidas para o Brasil: $R$. africanum, $R$. riparium e $R$. hieroglyphicum (C. Agardh) Kützing, esta última citada para águas continentais (Branco \& Necchi 1998, Moura 2016b). Rhizoclonium africanum e R. riparium possuem ampla distribuição no litoral brasileiro, se estendendo de Santa Catarina ao Amapá ( $R$. africanum) e do Rio Grande do Sul ao Amapá ( $R$. riparium) (Moura 2016b). Ambas espécies são comuns em manguezais, mas também encontradas em recifes de arenito e costões rochosos, crescendo da região entremarés até $10 \mathrm{~m}$ de profundidade (Alves et al. 2009, Rocha-Jorge 2015).

De acordo com Zhao et al. (2014), os critérios mais importantes que caracterizam o gênero são: longos filamentos não ramificados, ramificados apenas na região basal do talo ou com ramos rizoidais, e células com múltiplos cloroplastos formando um retículo com vários pirenoides, mais com pouco ou limitado número de núcleos [1-4 (-15)]. Ao contrário da circunscrição tradicional, Zhao et al. (2014) afirmam que Rhizoclonium pode ter ramos verdadeiros. Os caracteres comumente empregados para delimitação de espécies incluem o diâmetro do filamento, a razão comprimento/largura das células, a presença e números de rizoides e o habitat, se marinho ou de água doce.

Os espécimes de $R$. africanum estudados (Fig. 31A-C) são similares aos descritos por Taylor (1960), Joly (1965, como Rhizoclonium hookeri Kützing), Barata (2004), Coto \& Pupo (2009), Dawes \& Mathieson (2008), Alves et al. (2009), Almeida et al. (2012) e Rocha-Jorge (2015), especialmente nas medidas de diâmetro dos filamentos.

Morfologicamente, $R$. africanum é segregado de $R$. riparium pelo maior diâmetro do filamento ( $>80 \mu \mathrm{m}$ vs. $<60 \mu \mathrm{m}$ em $R$. riparium), ramos secundários ocasionais, junção intercalar em ângulo de $90^{\circ}$, semelhantes a "articulação de joelho", e rizoides laterais multicelulares, enquanto que em $R$. riparium os rizoides laterais são unicelulares (Coppejans et al. 2002, Alves et al. 2009, Almeida et al. 2012). Entretanto, ramificação rizoidal multicelular foi descrita para $R$. riparium por Zhao et al. (2014). A presença de rizoides multicelulares e junções intercalares em ângulo de $90^{\circ}$ foram 
frequentes no material estudado, assim como descrito por Alves et al. (2009) e Almeida et al. (2012), para material procedente da Bahia. A ocorrência de ramificação secundária no material estudado (Fig.31A-B), também descrita por Alves et al. (2009) e ilustrada por Almeida et al. (2012, Fig. 4e), corrobora a presença de ramos verdadeiros nesta espécie conforme salientado por Zhao et al. (2014).

O material estudado de $R$. riparium (Fig. 32A-C) está de acordo com as descrições dessa espécie fornecidas por Taylor (1960), Joly (1965), Barata (2004), Coto \& Pupo (2009), Dawes \& Mathieson (2008), Alves et al. (2009), Almeida et al. (2012) e Rocha-Jorge (2015), especialmente no diâmetro dos filamentos, que não ultrapassa $70 \mu \mathrm{m}$ (Zhao et al. 2014).

Estudos filogenéticos moleculares tem demonstrado que Rhizoclonium é polifilético, posicionando-se em clados que incluem Cladophora ou Chaetomorpha Kützing, sugerindo que a morfologia do tipo Rhizoclonium (filamentos essencialmente não ramificados com laterais rizoidais) evoluiu várias vezes independentemente em Cladophorales (Hanyuda et al. 2002, Leliaert et al. 2003).

Dados moleculares têm apontado que a espécie $R$. riparium e táxons morfologicamente relacionados, formam um complexo de espécies crípticas ou possivelmente uma espécie global polimórfica com populações poliploides (Leliaert \& Boedeker 2007).

Todas as nossas tentativas de sequenciamento do material coletado falharam e não há nenhum estudo molecular com espécies de Rhizoclonium feito no Brasil, indicando que investigações com ampla amostragem e abordagem molecular são necessárias para esclarecer o posicionamento e a delimitação das espécies brasileiras. 

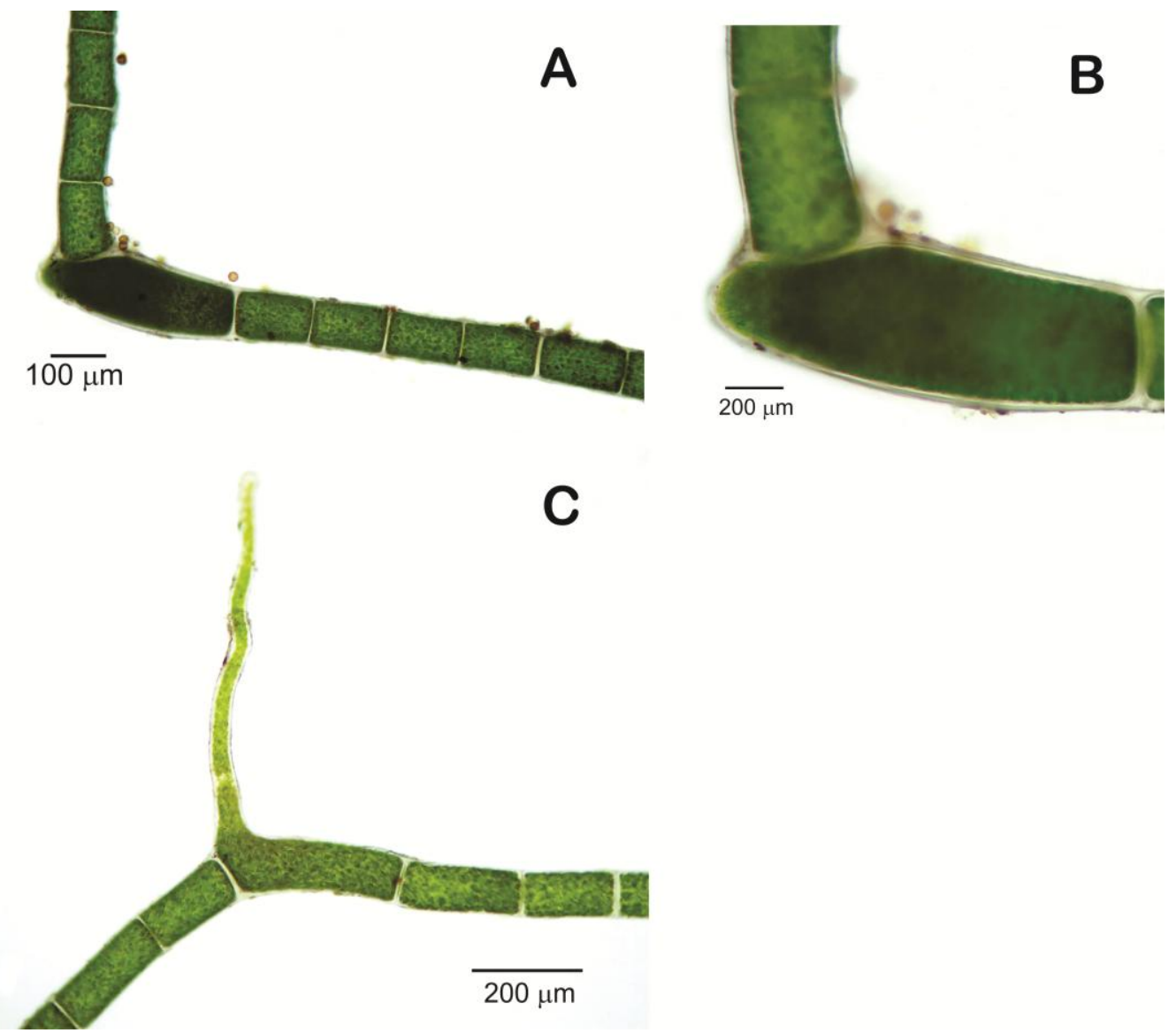

Figura 31 - Rhizoclonium africanum. A- Detalhe da ramificação secundária. B- Detalhe do septo na ramificação. C- Detalhe rizoide multicelular.

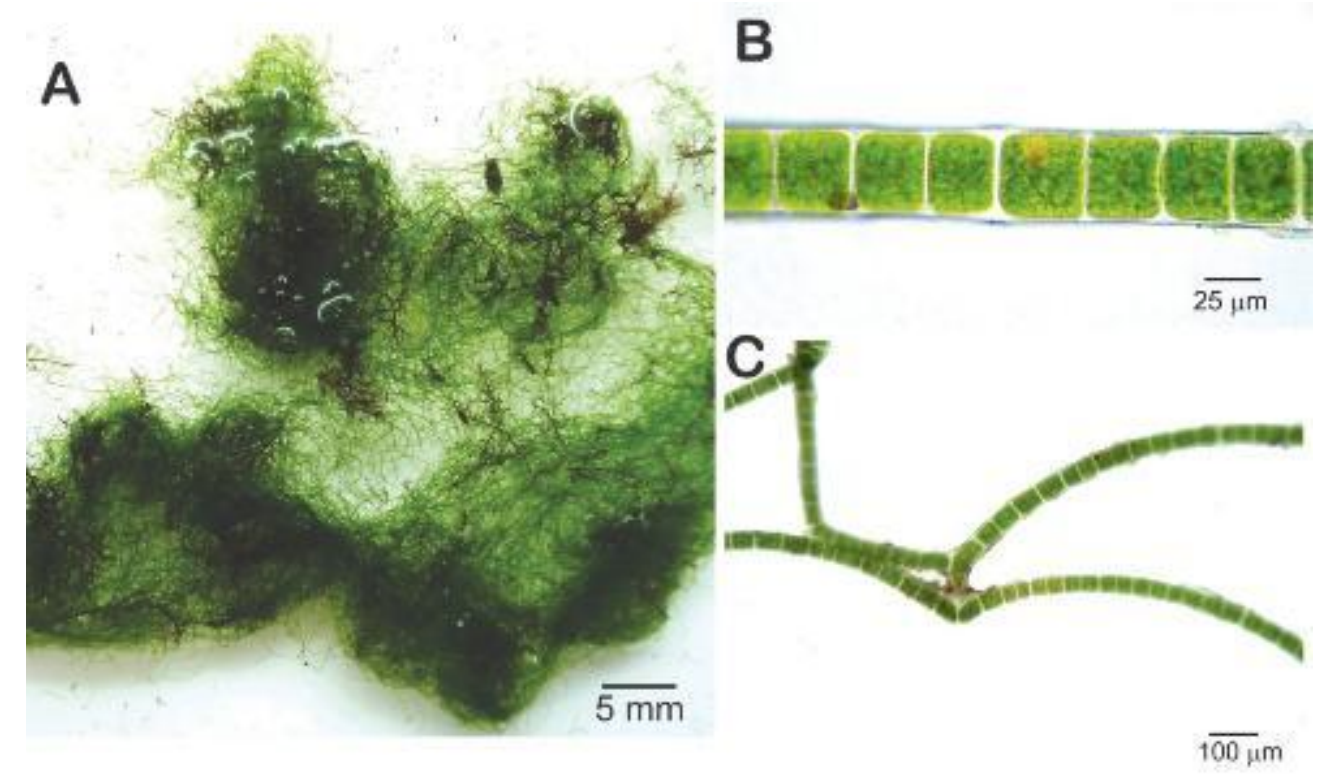

Figura 32 - Rhizoclonium riparium. A- Aspecto geral do talo formando tufos emaranhados. B- Detalhe do filamento unisseriado. C- Detalhe filamento com falsa ramificação. 
Apesar dos impactos antrópicos causados na llha Barnabé como as construções dos terminais portuários bem como os diversos eventos envolvendo lançamento de produtos químicos na região (derramamentos de óleo) e incêndios (Menghini 2008), a composição de espécies de macroalgas encontrada na área é semelhante à de outros manguezais estudados no Brasil (Eston et al. 1992, Yokoya et al. 1999, Cunha \& Costa 2002, Fontes 2012) e no mundo (Beanland \& Woelkerling 1982, Phillips et al. 1996, Laursen \& King 2000, Zuccarello et al. 2012). Considerando apenas Rhodophyta, Fernandes et al. (2005) observaram sete espécies para os manguezais do Pará, distribuídos nos gêneros Bostrychia, Caloglossa e Catenella, destas apenas B. pilulifera Montagne, referida somente para os estados do Amapá (Paula et al. 1989), Pará (Fernandes et al. 2005) e Maranhão (Cutrim \& Avezedo 2005), não foi encontrada na llha Barnabé. No nordeste, Cutrim (1998) e Fontes et al. (2007) registraram 14 e nove espécies, respectivamente.

No levantamento de macroalgas de manguezais do Maranhão realizado por Cutrim (1998), além dos gêneros citados acima, foram registradas espécies dos gêneros Centroceras Kützing, Ceramium Roth, Polysiphonia Greville e Murrayella F.Schmitz, enquanto Fontes et al. (2007) regitraram para manguezal de Permambuco, os gêneros Murrayella e Hypnea. Esses cinco gêneros não foram encontrados no presente estudo e tampouco no trabalho de Yokoya et al. (1999) para a região sudeste do país (São Paulo), para a qual Yokoya et al. (1999) observaram nove táxons. Na região sul do país (Santa Catarina), Hadlich \& Bouzon (1985) registraram a presença de nove táxons, entre eles espécies dos gêneros Polysiphonia e Murrayella. No presente estudo foram identificados 10 táxons de Rhodophyta, cuja composição de espécies foi mais similar a encontrada por Yokoya et al. (1999) para a llha do Cardoso (SP), excetuando o registro de Bostrychia kelanensis (como Stictosiphonia kelanensis (Grunow ex Post) King \& Puttock), não registrada na llha Barnabé.

Miranda \& Pereira (1989) avaliando a distribuição espaço-temporal das macroalgas no manguezal do Rio Ceará (CE) e correlacionando com as condições hidrológicas locais observaram que a variação da concentração salina influencia a composição de espécies. Assim, em áreas de manguezal mais próximas ao mar, onde não há variações significativas de salinidade, espécies como as dos gêneros citados acima, Centroceras, Ceramium e Hypnea, são comumente encontrados. 
Vale ressaltar que em todos os trabalhos citados acima, o gênero Bostrychia prevaleceu em número de táxons registrados. Entretanto, a citação de um maior número de táxons de Caloglossa encontrado neste estudo em comparação com os anteriores citados acima, e que foi desvendado essencialmente por dados moleculares, aponta para a subestimação desse gênero quando abordado apenas do ponto de vista morfológico.

Em relação as Chlorophyta, Cutrim (1998) citou cinco táxons, entretanto, Ulva Linnaeus (como Enteromorpha Link) e Caulerpa não foram encontrados na llha Barnabé. Yokoya et al. (1999) registraram oito táxons, desconsiderando Rhizoclonium kerneri Stockmayer sinonimizada com $R$. riparium. Entre as algas verdes citadas por Yokoya et al. (1999), quatro gêneros: Gayralia K.L.Vinogradova (como Ulvaria Ruprecht), Monostroma Thuret, Chaetomorpha Kützing [C. ligusta (Kützing) Kützing como Rhizoclonium tortuosum (Dillwyn) Kützing] e Ulva (como Enteromorpha), não foram encontrados na nossa área de estudo. Fontes et al. (2007) citaram as mesmas espécies observadas na llha Barnabé, com exceção de $B$. vaucherioidea encontrada pela primeira vez em manguezais brasileiros no presente trabalho. Fernandes et al. (2005) registraram o maior número de algas verdes em manguezais, nove espécies, entres elas, espécies de Caulerpa e Ulva (como Enteromorpha). Entre todas as algas verdes registradas em manguezais brasileiros, $C$. membranacea foi a espécie mais comum sendo referida em todos os estudos citados acima.

A análise preliminar morfológica realizada por Sena et al. (2012) sobre a comunidade de macroalgas que cresce sobre penumatóforos no manguezal da liha Barnabé registrou 10 táxons, os mesmos foram reencontrados no presente estudo acrescidos de mais cinco táxons, alguns deles revelados pela aborgagem molecular empregada.

No presente estudo, os gêneros Bostrychia e Caloglossa foram os mais representativos, cada um com quatro táxons identificados e ocorrendo nas três áreas amostradas em todas as coletas realizadas (Tabela 5). A parasita $D$. bostrychiae foi encontrada em todas as coletas sobre os hospedeiros " $B$. calliptera" e $B$. radicans. Dentre as espécies de Caloglossa, $C$. ogasawaraensis foi a mais comum, enquanto 
C. apomeiotica foi encontrada apenas uma vez, na área 3 - noroeste da llha Barnabé. Excetuando $B$. vaucherioidea, cuja ocorrência foi restrita à área 2 em duas épocas do ano, as demais algas verdes foram frequentes ocorrendo em todas as coletas das áreas amostradas.

Tabela 6-Ocorrência dos táxons identificados por estações de coleta/amostragem.

\begin{tabular}{|c|c|c|c|c|c|}
\hline \multirow{3}{*}{$\begin{array}{c}\text { Espécies } \\
\text { identificadas }\end{array}$} & \multicolumn{5}{|c|}{ Estações de Coleta } \\
\hline & \multicolumn{2}{|c|}{ Área 1 - Norte } & \multicolumn{2}{|c|}{ Área 2 - Sul } & \multirow{2}{*}{$\begin{array}{c}\text { Área } 3 \text { - Noroeste } \\
\text { Junho/2013 }\end{array}$} \\
\hline & Fevereiro/2013 & Setembro/2013 & Setembro/2013 & Fevereiro/2014 & \\
\hline B. pusilla & $\mathbf{x}$ & $\mathbf{x}$ & $\mathbf{x}$ & $\mathbf{x}$ & $\mathbf{x}$ \\
\hline B. vaucherioidea & - & - & $\mathbf{x}$ & $\mathbf{x}$ & - \\
\hline "C. membranacea" & $\mathbf{x}$ & $\mathbf{x}$ & $\mathbf{x}$ & $\mathbf{x}$ & $\mathbf{x}$ \\
\hline R. africanum & $\mathbf{x}$ & $\mathbf{x}$ & $\mathbf{x}$ & $\mathbf{x}$ & $\mathbf{x}$ \\
\hline R. riparium & $\mathbf{x}$ & $\mathbf{x}$ & $\mathbf{x}$ & $\mathbf{x}$ & $\mathbf{x}$ \\
\hline "B. calliptera" & $\mathbf{x}$ & $\mathbf{x}$ & $\mathbf{x}$ & $\mathbf{x}$ & $\mathbf{x}$ \\
\hline B. montagnei & $\mathbf{x}$ & $\mathbf{x}$ & - & - & - \\
\hline B. moritziana 1 & $\mathbf{x}$ & $\mathbf{x}$ & - & - & - \\
\hline B. moritziana 2 & - & - & $\mathbf{x}$ & $\mathbf{x}$ & - \\
\hline B. radicans 1 & $\mathbf{x}$ & $\mathbf{x}$ & $\mathbf{x}$ & $\mathbf{x}$ & $\mathbf{x}$ \\
\hline B. radicans 2 & $\mathbf{x}$ & $\mathbf{x}$ & $\mathbf{x}$ & $\mathbf{x}$ & $\mathbf{x}$ \\
\hline C. apomeiotica & - & - & - & - & $\mathbf{x}$ \\
\hline C. confusa & $\mathbf{x}$ & $\mathbf{x}$ & - & - & - \\
\hline C. leprieurii & - & - & $\mathbf{x}$ & $\mathbf{x}$ & - \\
\hline C. ogasawaraensis & $\mathbf{x}$ & $\mathbf{x}$ & $\mathbf{x}$ & $\mathbf{x}$ & - \\
\hline C. caespitosa & $\mathbf{x}$ & $\mathbf{x}$ & $\mathbf{x}$ & $\mathbf{x}$ & - \\
\hline D. bostrychiae & $\mathbf{x}$ & $\mathbf{x}$ & $\mathbf{x}$ & $\mathbf{x}$ & $\mathbf{x}$ \\
\hline
\end{tabular}

\section{CONSIDERAÇÕES FINAIS}

O estudo molecular e morfológico das espécies de macroalgas da llha Barnabé permitiu identificar 17 espécies, 12 Rhodophyta e cinco Chlorophyta, das quais apenas três puderam ser confirmadas por comparação com sequências das suas localidades-tipo, as quais apresentaram baixa divergência intraespecífica com as nossas sequências: $C$. apomeiotica, $C$. leprieurii e $C$. confusa. A espécie críptica $C$. ogasawaraensis forma três linhagens genéticas verificadas por Kamiya \& West (2014), em uma das quais se enquadraram nossos espécimes (linhagem do Atlântico- 
Pacífico/Malásia). Embora não haja sequências da localidade tipo de $C$. ogasawaraensis (Ogasawara-jima, Bonin Islands) para comparação, sequências do Japão, região mais próxima à localidade tipo estão disponíveis, sendo que as sequências japonesas fazem parte de outra linhagem filogenética (Pacífico ocidental/Micronesia/Madagascar). A divergência intraespecífica máxima do rbcL entre as três linhagens de $C$. ogasawaraensis (5,2\%) indica que estas poderiam ser descritas como espécies distintas. Porém, Kamiya \& West (2014) preferiram adotar um posicionamento conservador argumentando que mais características são necessárias para descrever os grupos filogenéticos como espécies diferentes. Nossos resultados mostraram, sem dúvida, que os espécimes brasileiros fazem parte do complexo C. ogasawaraensis.

O reconhecimento de espécies crípticas e polifiléticas em Bostrychia não é recente na literatura e vem sendo confirmado desde Zuccarello \& West $(2003,2006)$. Das quatro espécies identificadas neste estudo, apenas $B$. montagnei não forma complexo de espécies e mostrou-se bem definada tanto do ponto de vista morfológico quanto molecular, apresentando baixa divergência genética intraespecífica para todos os marcadores utilizados. O complexo $B$. radicans/moritziana forma sete linhagens distintas reconhecidas por Zuccarello et al. (2009). Espécimes brasileiros desse complexo, analisados neste estudo, formaram cinco linhagens moleculares com alta divergência intraespecífica. Entretanto, não há características morfológicas que sustentem todas as diferentes linhagens desse complexo. Pelas nossas análises morfológicas, o maior tamanho do talo e o padrão de ramificação alterno-dístico mais denso de $B$. radicans 2 a separa do agrupamento denominado $B$. radicans 1 , enquanto talos mais delicados e menos ramificados diferem B. moritziana 2 de B. moritziana 1 . As caraterísticas taxonômicas de valor diagnóstico correntemente empregadas para separação de espécies de Bostrychia são insuficientes para a separação dessas linhagens moleculares.

Nossos espécimes de " $B$. calliptera" apresentaram alta divergência genética com B. callipetra de Fontes (2012) e apresentam morfologia B. pinnata, atualmente considerada um sinônimo de $B$. calliptera. A possibilidade de restabelecimento de $B$. pinnata deve ser considerada, entretanto, mais estudos morfológicos e moleculares são necessários para redefinição do status taxonômico de $B$. pinnata. 
Os espécimes identificados como Catenella caespitosa neste estudo mostraram alta divergência intraespecífica com sequências dessa espécie disponíveis nos bancos de dados para o marcador SSU rDNA, apesar de morfologicamente se enquadrem perfeitamente nas descrições de $C$. caespitosa da literatura. Os resultados como o SSU rDNA sugerem que a citação dessa espécie para o Brasil pode estar equivocada. Não há sequências da localidade tipo para comparação (Side Rocks, Anglesey, Wales, UK), tampouco sequências de outros marcadores nos bancos de dados. O estudo molecular do gênero Catenella ainda é muito incipiente e aparentemente negligenciado, talvez pela suposta facilidade de identificação genérica e específica. Nossos resultados ainda que preliminares apontam para uma possível diversidade críptica em $C$. caespitosa. As sequências obtidas neste estudo são as primeiras da espécie para o Brasil e há necessidade de maior amostragem e utilização de outros marcadores moleculares, especialmente os do tipo "DNA Barcode". O gênero merece investigações mais aprofundadas globalmente tanto do ponto de vista molecular quanto morfológico para esclarecer sua diversidade específica.

Para a maioria das espécies de algas verdes encontradas neste estudo não foi possível a confirmação de sua identificação utilizando técnicas moleculares, ou por falhas na amplificação e sequenciamento das amostras ou por falta de sequências nos bancos de dados para comparação. Portanto, a obtenção de sequências para o nosso material foi extremamente laboriosa e problemática exigindo inúmeras tentativas de amplificação e sequenciamento. O marcador padrão do tipo "DNA Barcode" para as algas verdes, tufA falhou para todas as espécies analisadas, não apenas para Cladophoraceae, cuja ineficiência já é relatada na literatura (Saunders \& Kucera 2010), mas também para o outro representante de Cladophorales (Cladophoropsis), assim como para os representantes de Bryopsidales (Boodleopsis). Marcadores alternativos foram utilizados como o ITS rDNA nuclear e SSU rDNA, além do $r b c L$ e do marcador do tipo "DNA Barcode", UPA. Todos falharam na amplificação de amostras de Rhizoclonium e igualmente não foi possível obter sequências de UPA e SSU rDNA para nenhuma outra espécie de alga verde estudada. Apenas para Boodleopsis vaucherioidea foi possível obter sequências parciais de $r b c \mathrm{~L}$, o que inviabilizou a comparação com nossos espécimes de B. pusilla. A comparação entre a única sequência parcial de $r b c L$ de $B$. pusilla disponível nos bancos de dados e as nossas amostras de $B$. vaucherioidea mostrou baixa divergência genética $(0,5 \%)$. A 
proposta de uma possível coespecificidade dessas espécies exige maior amostragem, sequenciamento completo do rbcL e comparação com sequências das localidades tipo, além do uso de outros marcadores moleculares.

Cladophoropsis membranacea forma seis linhagens filogenéticas de acordo com os resultados de ITS rDNA nuclear obtidos por Leliaert et al. (2009). Nossos espécimes não se posicionaram em nenhuma delas e se mantiveram externas a todo o complexo Boodlea. Mantivemos o nome "C. membranacea" seguindo Leliaert et al. (2009), entretanto essa espécie necessita de maior amostragem na costa brasileira e a obtenção de sequências de outros marcadores nucleares para melhor compreender o posicionamento de "C. membranacea" dentro das Cladophorales. De acordo com Leliaert (com. pess.) apesar de todo o esforço na investigação dessas algas verdes, o clado "Siphonocladales" ainda teria de ser revisto.

Para as algas vermelhas o marcador COI-5P também foi muito problemático para obtenção de sequências com uma taxa de sucesso muito menor do que o UPA. Embora o UPA seja mais conservado, este marcador foi eficiente para o gênero Bostrychia, resolvendo praticamente os mesmos grupos genéticos que o $\mathrm{COI}-5 \mathrm{P}$, com exceção de $B$. radicans com uma linhagem a menos detecteda pelo UPA. O UPA também foi eficiente para Caloglossa, ao contrário dos resultados de Kano (2015). Não houve sobreposição entre valores de divergência intraespecífica e interespecífica para o UPA pelos nossos resultados, diferentemente do observado por Yang \& Kim (2014) para as Halymeniaceae. Entretanto, o UPA pode não ser um marcador efetivo na resolução de espécies estreitamente relacionadas, uma vez que a menor divergência interespecífica poderia levar a uma subestimação da diversidade, como já salientado na literatura (Saunders \& Kucera 2010, Clarkston \& Saunders 2013).

Os resultados obtidos neste estudo sobre as macroalgas da llha Barnabé demonstram que é necessário um grande esforço amostral e maiores análises moleculares para se desvendar a diversidade específica de macroalgas de manguezais brasileiros. 


\section{REFERÊNCIAS}

Agostinho, D.C. \& Necchi Jr., O. 2014. Systematics of the section Virescentia of the genus Batrachospermum (Batrachospermales, Rhodophyta) in Brazil. Phycologia 53: 561-570.

Almeida, W.R. 2013. Macroalgas marinhas bentônicas da llha Bimbarras, região norte da Baía de Todos os Santos, Bahia, Brasil. Dissertação de Mestrado. Universidade Estadual de Feira de Santana. 408 p.

Almeida, W.R., Alves, A.M., Guimarães, S.M.P.B. \& Moura, C.W.N. 2012. Cladophorales and Siphonocladales (Chlorophyta) from Bimbarras Island, Todos os Santos Bay, Bahia State, Brazil. Iheringia, Sér. Bot. 67: 149-164.

Alvarez, I. \& Wendel, J.F. 2003. Ribosomal ITS sequences and plant phylogenetic inference. Molecular phylogenetics and evolution 29: 417-434.

Alves, A.M., Moura, C.W.N., Alves, G.L. \& Gestinari, L.M.S. 2009. Os gêneros Chaetomorpha Kütz. nom. cons. e Rhizoclonium Kütz. (Chlorophyta) do litoral do Estado da Bahia, Brasil. Revista Brasileira de Botânica 32: 545-570.

Barata, D. 2004. Clorofíceas marinhas bentônicas do Estado do Espírito Santo. Dissertação de Mestrado, Instituto de Botânica, São Paulo, 210p.

Barata, D. 2008. Taxonomia e filogenia do gênero Caulerpa J.V. Lamouroux (Bryopsidales, Chlorophyta) no Brasil. Tese de Doutorado. Instituto de Botânica de São Paulo, 200p.

Barros-Barreto, M.B., Mclvor, L., Maggs, C.A. \& Ferreira, P.C.G. 2006. Molecular systematics of Ceramium and Centroceras (Ceramiaceae, Rhodophyta) from Brazil. Journal of Phycology 42: 905-921.

Bird C.J., Rice E.L., Murphy C.A. \& Ragan M.A. 1992. Phylogenetic relationships in the Gracilariales (Rhodophyta) as determinedby 18S rDNA sequences. Phycologia 31:510 522.

Bouzon, Z.L. \& Ouriques, L.C. 1999. Occurrence and distribution of Bostrychia and Caloglossa (Rhodophyta, Ceramiales) in the Ratones River Mangrove, Florianópolis-SC-Brazil. Insula 28:43-52.

Branco, L.H.Z. \& Necchi, O.Jr. 1998. Distribution of stream macroalgae in three tropical drainage basin of southeastern Brazil. Archiv für Hydrobiologie 142: 241-256.

Calderón-Sáenz, E. \& Schnetter. R.1989. The life histories of Boodleopsis vaucherioidea sp. nov. and B. pusilla (Caulerpales) and their phylogenetic implications. Phycologia 28: 476-490.

Caridade, E. \& Ferreira-Correia, M.M. 2007. Taxonomia das macroalgas dos manguezais da Baía de Turiaçu, Estado do Maranhão, Brasil. Boletim do Laboratório de Hidrobiologia 65085:53.

Cassano, V. 2009. Taxonomia e filogenia do complexo Laurencia (Ceramiales, Rhodophyta), com ênfase no estado do Rio de Janeiro, Brasil. São Paulo, Tese de Doutorado, Instituto de Botânica de São Paulo. 328p. 
Cassano, V., Brito, L.V.R. \& Széchy, M.T.M. 2004. The occurrence of Boodleopsis vaucherioidea Calderón-Sáenz et Schnetter (Udoteaceae, Chlorophyta) in Brazil. Botanica Marina 47: 251-254.

Cassano, V., Díaz-Larrea, J., Sentíes, A., Oliveira, M.C., Gil-Rodríguez, M.C. \& Fujii, M.T. 2009. Evidence for the conspecificity of Palisada papillosa with P. perforata (Ceramiales, Rhodophyta) from the western and eastern Atlantic Ocean on the basis of morphological and molecular analyses. Phycologia 48: 86-100.

Cassano, V., Oliveira, M.C., Gil-Rodríguez, M.C., Sentíes, A., Díaz-Larrea, J. \& Fujii, M.T. 2012. Molecular support for the establishment of the new genus Laurenciella within the Laurencia complex (Ceramiales, Rhodophyta). Botanica Marina 55: 349-357

Chase, M.W.; Salamin, N.; Wilkinson, M.; Dunwell, J.M.; Kesanakurthi, R.P.; Haidar, N.; Savolainen, V. 2005 Land plants and DNA barcoding: short-term and long-term goals. Philosophical Transactions of The Royal Society, B 360.

Clarkston, B.E. \& Saunders, G.W. 2010. A comparison of two DNA barcode markers for species discrimination in the red algal family Kallymeniaceae (Gigartinales, Florideophyceae), with a description of Euthora timburtonii sp. nov. Botany 88:119-131.

Clarkston B.E. \& Saunders G.W. 2013. Resolving species diversity in the red algal genus Callophyllis (Kallymeniaceae, Gigartinales) in Canada using molecular assisted alpha taxonomy. European Journal of Phycology 48: 27-46.

CETESB. 1991. Avaliação do estado da degradação dos ecossistemas da Baixada Santista. CETESB, São Paulo.

Coppejans, E., Leliaert, F. \& Schils, T. 2002. New records of marine benthic algae for the Mozambican coast, collected at Inhaca Island. South African Journal of Botany 68:342348.

Cordeiro-Marino, M. 1978. Rodofíceas bentônicas marinhas do estado de Santa Catarina. Rickia 7: 1-243.

Costa E.S., Plastino E.M., Petti R., Oliveira E.C. \& Oliveira M.C. 2012. The Gracilariaceae Germplasm Bank of the University of São Paulo, Brazil-a DNA barcoding approach. Journal of Applied Phycology 24: 1643 - 1653.

Coto, A.C.S.P. \& Pupo, D. 2006. Flora ficológica do Estado de São Paulo, vol. 3. Ulvophyceae, São Carlos: RiMa Editora, FAPESP, 86p.

Cunha, S.R. \& Costa, C.S. 2002. Gradientes de salinidade e freqüência de alagamento como determinantes da distribuição e biomassa de macroalgas associadas a troncos de manguezais na Baía de Babitonga, SC. Brazilian Journal of Aquatic Science and Technology 6:93-102.

Cunha, S.R. \& Duarte, N.R. 2002. Taxas Fotossintéticas e Respiratórias de Macroalgas do Gênero Bostrychia (Rhodomelaceae, Rhodophyta). Brazilian Journal of Aquatic Science and Technology 6:103-110.

Cunha, S.R., Nascimento, J., Zacharjasiewicz, G., Crestani, D., Mafra Jr, L.L., Pazeto, F., Sant'anna, F. \& Costa, C. 1999. Distribuição e biomassa de macroalgas em um manguezal da Baía da Babitonga, SC: Resultados Preliminares. Brazilian Journal of Aquatic Science and Technology 3:1-15. 
Curtis, N. E., Dawes, C. J. and Pierce, S. K. 2008. Phylogenetic analysis of the large subunit rubisco gene supports the exclusion of Avrainvillea and Cladocephalus from the Udoteaceae (Bryopsidales, Chlorophyta). Journal of Phycology, 44: 761-767.

Cutrim, M.V.J., SILVA, E.F. \& AZEVEDO, A.C.G. 2004. Distribuição vertical das macroalgas aderidas em rizóforos de Rhizophora mangle Linnaeus nos manguezais de Parna-Açu e Tauá-Mirim (Ilha de São Luís/MA-Brasil). Boletim do Laboratório de Hidrobiologia 17:9-18.

Dawes, C.J. \& Mathieson, A.C. 2008. The Seaweeds of Florida. University Press of Florida, $592 \mathrm{p}$.

Díaz-Larrea, J., Sentíes, A., Fujii, M.T., Pedroche, F.F. \& Oliveira, M.C. 2007. Molecular evidence for Chondrophycus poiteaui var. gemmiferus comb. et stat. nov. (Ceramiales, Rhodophyta) from the Mexican Caribbean Sea: implications for the taxonomy of the Laurencia complex. Botanica Marina 50: 250-256.

Dijoux, L., Verbruggen, H., Mattio, L., Doung, N. \& Payri, C. 2012 Diversity of Halimeda (Bryopsidales, Chlorophyta) in New Caledonia: A combined morphological and molecular study. Journal of Phycology 48: 1465-1481.

Diretoria de Hidrografia e Navegação (http://www.mar.mil.br/dhn/chm/tabuas/index.htm). acessado em 3/julho/2012.

Eston, V.R., Braga, M.R.A., Cordeiro-Marino, M., Fujii, M.T. \& Yokoya, N.S. 1992. Macroalgal colonization patterns on artificial substrates inside southeastern Brazilian mangroves. Aquatic Botany 42:315-325

Falkenberg, P. 1901. Die Rhodomelaceen des golfes von Neapel und der angrenzenden Meeres-abschnitte. Fauna und Flora des Golfes von Neapel und der angrenzenden Meeres-abschnitte 26: 1-754.

Famà, P., Wysor, B., Kooistra, W.H.C.F., Zuccarello, G.C. 2002. Molecular phylogeny of the genus Caulerpa (Caulerpales, Chlorophyta) inferred from chloroplast tufA gene. Journal of Phycology 38: 1040-1050.

Feliner, G.N. \& Rossello, J.A. 2007. Better the devil you know? Guidelines for insightful utilization of nrDNA ITS in species species-level evolutionary studies in plants. Molecularphylogenetics and evolution 44: 911-919.

Fernandes, M.E.B. \& Alves, E. de F.S. 2011. Occurrence and distribution of macroalgae (Rhodophyta) associated with mangroves on the Ajuruteua peninsula, Bragança, Pará, Brazil. UAKARI 7:35-42.

Fernandes, M.E.B., Silva, E.F., Lima, J.F., Varela, E.S. \& Hercos, A.P. 2005. Distribuição espacial das macroalgas associadas às florestas de mangue na península de Ajuruteua, Bragança-Pará. Boletim do Laboratório de Hidrobiologia. 18:11-17.

Fontes, K.A.A. 2012. Taxonomia e distribuição geográfica do gênero Bostrychia montagnei (Ceramiales-Rhodophyta) nos manguezais do litoral brasileiro. Tese de Doutorado. Universidade Federal Rural de Pernambuco, 94p.

Fraser, C.I., Zuccarello, G.C., Spencer, H.G., Slvatore, L.C., Garcia, G.R. \& Waters, J.M. 2013. Genetic Affinities between Trans-Oceanic Populations of Non-Buoyant Macroalgae in the High Latitudes of the Southern Hemisphere. PLOSONE 8(7): e69138. doi:10.1371/journal.pone.0069138. 
Fredericq, S., Hommersand, M. H. \& Freshwater, D. W. 1996. The molecular systematics of some agar- and carrageenam-containing marine red algae based on $r b c \mathrm{~L}$ sequence analysis. Hydrobiologia 326/327: 125-135.

Fredericq, S., Freshwater, D. W. \& Hommersand, M. H. 1999. Observations on the phylogenetic systematics and biogeography of the Solieriaceae (Rhodophyta, Gigartinales) inferred from $r b c L$ sequences and morphological evidence. Hydrobiologia 398/399: 25-38.

Freshwater, D.W. \& Rueness, J. 1994. Phylogenetic relationships of some European Gelidium Gelidiales (Rhodophyta) species, based on $r b c \mathrm{~L}$ nucleotide sequence analysis. Phycologia 33: 187-194.

Freshwater, D.W., Fredericq, S. \& Hommersand, M.H. 1995. A molecular phylogeny of the Gelidiales (Rhodophyta) based on analysis of plastid $r b c \mathrm{~L}$ nucleotides sequences. Journal of Phycology 31: 616-632.

Freshwater D.W., Fredericq S., Bradley, B.S., Hommersand M.H. \& Chase M.W. 1994. A gene phylogeny of the red algae (Rhodophyta) based on plastid rbcL. Proceedings of the National Academy of Sciences of the United States of America 91: 7281-7285.

Fujii, M.T.; Cassano, V. Bostrychia in Lista de Espécies da Flora do Brasil. Jardim Botânico do Rio de Janeiro. Disponível em: $<$ http://floradobrasil.jbrj.gov.br/jabot/floradobrasil/FB99838>, acessado em 16 Dez. 2015.

Fujii, M.T. \& Guimarães, S.M.B.P. 1999. Morphological studies of the parasitic red alga Janczewskia moriformis (Rhodomelaceae, Ceramiales) from Brazil. Phycologia 38: 1-7.

Goff, L. J. 1982. The biology of parasitic red algae. Progress in Phycological Research: 289369.

Guiry, M.D. \& Guiry, G.M. 2015. AlgaeBase. World-wide electronic publication, National University of Ireland, Galway. http://www.algaebase.org; searched on 16 December 2015.

Guiry, M.D. \& Guiry, G.M. 2016. AlgaeBase. World-wide electronic publication, National University of Ireland, Galway. http://www.algaebase.org; searched on 04 January 2016.

Gurgel, C. F. D. \& Fredericq, S. 2004. Systematics of the Gracilariaceae (Gracilariales, Rhodophyta): a critical assessment based on $r b c L$ sequence analyses. Journal of Phycology 40: 138-159.

Hadlich, R.M. 1984. Contribuição ao levantamento taxonômico das algas marinhas bentônicas do mangue de Itacorubi-Florianópolis, Ilha de Santa Catarina, Brasil, I: Chlorophyta. Ínsula 14: 121-138.

Hadlich, R.M. \& Bouzon, Z.L. 1985. Contribuição ao levantamento taxonômico das algas marinhas bentônicas do mangue do Itacorubi-Florianópolis-llha de Santa CatarinaBrasil-II Rhodophyta. Insula 15:89-116.

Hall, T.A. 1999. BioEdit: a user-friendly biological alignment editor and analysis program for Windows 95/98/NT. Nucleic Acids Symposium Series 41: 95-98.

Hanisak, M. 1993. Nitrogen release from decomposing seaweeds: species and temperature effects. Journal of Applied Phycology 5:175-181. 
Hanyuda, T., Wakana, I., Arai, S., Miyaji, K., Watano, Y. \& Ueda, K. 2002. Phylogenetic relationships within Cladophorales (Ulvophyceae, Chlorophyta) inferred from 18S rRNA gene sequences, with special reference to Aegagropila linnaei. Journal of Phycology 38: 564-571.

Hebert, P.D.N., Cywinska, A., Ball, S.L. \& DeWaard, J.R. 2003. Biological identifications through DNA barcodes. Proceedings of the Royal Society B: Biological Sciences 270:313-321.

Hollenberg, G.J. 1967. New genera in the Rhodomelaceae from the Central Pacific. Bulletin of the Southern California Academy of Scences 66: 201-221.

Hooker J.D. \& Harvey W.H. 1847. Algae tasmanicae. London Journal of Botany 6: 397-417.

Iha, C. 2014. Diversidade de Gelidiales (Rhodophyta) baseada em marcadores moleculares e estudos morfoanatômicos para região Sudeste do Brasil. Dissertação de Mestrado. Universidade de São Paulo, 210 p.

Iha C., Milstein D., Guimarães S.M.P.B., Freshwater D.W. \& Oliveira M.C. 2015. DNA barcoding reveals high diversity in the Gelidiales of the Brazilian southeast coast. Botanica Marina 58: 295-305.

Joly, A. B. 1954. The genus Bostrychia Montagne in southern Brazil. taxonomic and ecological data. Boletim da Faculdade de Filosofia, Ciências e Letras da Universidade de São Paulo, série Botânica 11: 55-74.

Joly, A.B. 1957. Contribuição ao conhecimento da flora ficológica marinha da Baía de Santos e Arredores. Boletim da Faculdade de Filosofia, Ciências e Letras da Universidade de São Paulo, Botânica 14: 3-199.

Joly, A.B. 1965. Flora marinha do litoral norte do estado de São Paulo e regiões circunvizinhas. Boletim da Faculdade de Filosofia, Ciências e Letras da Universidade de São Paulo, série Botânica 21: 1-393.

Joly, A.B. \& Yamaguishi-Tomita, N. 1967. Dawsoniella bostrychiae a new parasite of mangrove algae. Sellowia 19: 63-70.

Joly, A.B. \& Yamaguishi-Tomita, N. 1969. Note on Dawsoniella Joly \& Yamaguishi-Tomita. Rickia 4: 209-210.

Kamiya, M., Tanaka, J., King, R.J, West, J.A., Zuccarell,o G.C. \& Kawai, H. 1999. Reproductive and genetic distinction between broad and narrow entities of Caloglossa continua (Delesseriaceae, Rhodophyta). Phycologia 38: 356-367.

Kamiya, M., Zuccarello, G.C. \& West, J.A. 2003. Evolutionary relationships of the genus Caloglossa (Delesseriaceae, Rhodophyta) inferred from large-subunit ribosomal RNA gene sequences, morphological evidence and reproductive compatibility, with description of a new species from Guatemala. Phycologia 42: 478-497

Kamiya, M. \& West, J.A. 2014. Cryptic diversity in the euryhaline red alga Caloglossa ogasawaraensis (Delesseriaceae, Ceramiales). Phycologia 53: 374-382

Kanagawa, A. 1984. Clorofíceas marinhas bentônicas do estado da Paraíba, Brasil. Tese. De Doutorado, Instituto de Biociências, Universidade de São Paulo, 470p. 
Kano, C.H. 2015. Delesseriaceae (Ceramiales, Rhodophyta) no sudeste brasileiro baseado em morfologia, DNA barcode e distribuição geográfica. Dissertação de Mestrado, Instituto de Botânica, São Paulo, 101p.

Kano, C.H. \& Fujii, M.T. 2016. Caloglossa in Lista de Espécies da Flora do Brasil. Jardim Botânico do Rio de Janeiro. Disponível em: <http://floradobrasil.jbrj.gov.br/jabot/floradobrasil/FB99891 >. Acesso em: 04 Jan. 2016.

Kano, C.H., Sena, F., Cassano, V. \& Fujii, M.T. 2016. Diversity of of Caloglossa species with emphasis on the southeastern Brazil accessed by morphology and DNA barcoding. Brazilian Journal of Botany (BRJB-D-15-00348, submetido).

King, R. J., Puttock, C. 1989. Morphology and taxonomy of Bostrychia and Stictosiphonia (Rhodomelaceae, Rhodophyta). Australian Systematic of Botany 21: 1-73.

King, R. J., Puttock, C. \& Paula, E. J. 1991. The morphology of Bostrychia pilulifera .Montagne (Rhodomelaceae, Rhodophyta) Japanese Journal of Phycology 39: 31-36.

Kooistra, W.H.C.F., Olsen, J.L., Stam, W.T. \& van Den Hoek, C. 1993. Problems relating to species sampling in phylogenetic studies: an example of non-monophyly in Cladophoropsis and Struvea (Siphonocladales, Chlorophyta). Phycologia 32: 419-428.

Krayesky, D.M., Norris, J., West, J.A. \& Fredericq, S. 2011. The Caloglossa leprieurii complex (Delesseriaceae, Rhodphyta) in the Americas: the elucidation of overlooked species based on molecular and morphological evidence. Cryptogamie Algologie 32: 37-62.

Kurihara, A., Abe, T., Tani, M. \& Sherwood, A.R. 2010. Molecular phylogeny and evolution of red algal parasites: a case study of Benzaitenia, Janczewskia, and Ululania (Ceramiales). Journal of Phycology 46: 580-590.

Le Gall, L. \& Saunders, G.W. 2010. DNA Barcoding is a powerful tool to uncover algal diversity: A case study of the Phyllophoraceae (Gigartinales, Rhodophyta) in the Canadian flora. Journal of Phycology 46: 374-389.

Leliaert, F., Rousseau, F., De Reviers, B. \& Coppejans, E. 2003. Phylogeny of the Cladophorophyceae (Chlorophyta) inferred from partial LSU rRNA gene sequences: is the recognition of a separate order Siphonocladales justified? European Journal of Phycology 38: 233-246.

Leliaert, F. \& Coppejans, E. 2006. A revision of Cladophoropsis Børgesen (Siphonocladales, Chlorophyta). Phycologia 45: 657-679.

Leliaert, F. \& Boedeker, C. 2007. Cladophorales. In: Brodie J., Maggs C.A. \& John D. (eds.) Green seaweeds of Britain and Ireland. The British Phycological Society. pp 131183.

Leliaert, F., Millar, A.J.K., Vlaeminck, C. \& Coppejans, E. 2007a. Systematics of the green macroalgal genus Chamaedoris Montagne (Siphonocladales), with an emended description of the genus Struvea Sonder. Phycologia 46: 709-725.

Leliaert, F., De Clerck, O., Verbruggen, H., Boedeker, C.\& Coppejans, E. 2007b. Molecular phylogeny of the Siphonocladales (Chlorophyta: Cladophorophyceae). Molecular Phylogenetics and Evolution 44: 1237-1256.

Leliaert, F., Wysor, B., Verbruggen, H., Vlaeminck, C. \& De Clerck, O. 2008. Phyllodictyon robustum (Setchell et Gardner) comb. nov. (Siphonocladales, Chlorophyta), a 
morphologically variable species from the tropical Pacific coast of America. Cryptogamie Algologie 29: 217-233.

Leliaert, F., Verbruggen, H., Wysor, B. \& De Clerck, O. 2009. DNA taxonomy in morphologically plastic taxa: Algorithmic species delimitation in the Boodlea complex (Chlorophyta: Cladophorales). Molecular Phylogenetics and Evolution 53: 122-133.

Littler, D.S. \& Littler, M.M. 2000. Caribbean reef plants. Offshore Graphics Inc., Washington, DC. $542 p$.

Luederwaldt, H. 1919. Os manguesais de Santos. Revista do Museu Paulista 11: 309-408.

Lewis, C.T., Bilkhu, S., Robert, V., Eberhardt, U., Szoke, S., Seifert, K.A. \& Lévesque, C.A. 2011. Identification of Fungal DNA Barcode targets and PCR Primers based on Pfam protein families and taxonomic hierarchy. Open Applied Informatics Journal 5:72-86.

Lugo, A.E. \& Snedaker, S.C. 1974. The Ecology of Mangroves. Annual Review of Ecology and Systematics 5:39-64.

Lyra, G.D.M., Costa, E.D.S., de Jesus, P.B., de Matos, J.C.G., Caires, T.A., Oliveira, M.C., Oliveira, E.C., Xi, Z., Nunes, J.M.D.C. \& Davis, C.C. 2015. Phylogeny of Gracilariaceae (Rhodophyte): evidence from plastid and mitochondrial nucleotide sequences. Journal of Phycology 51: 356-366.

Mamoozadeh, N.R.\& Freshwater, D.W. 2012. Polysiphonia sensu lato (Ceramiales, Florideophyceae) speciesof Caribbean Panama including Polysiphonia lobophoralis sp. nov. and Polysiphonia nuda sp. nov . Botanica Marina 55: 317-347.

Mann, F.D. \& Steinke, T.D. 1988. Photosynthetic and respiratory responses of the mangroveassociated red algae, Bostrychia radicans and Caloglossa leprieurii. South African Journal of Botany 54:203-207.

McDevit, D.C. \& Saunders, G.W. 2009. On the utility of DNA barcoding for species differentiation among brown macroalgae (Phaeophyceae) including a novel extraction protocol. Phycological Research 57:131-141.

Menghini, R.P. 2008. Dinâmica da recomposição natural em bosques de mangue impactados: Ilha Barnabé (Baixada Santista), SP, Brasil. Doutorado, Universidade de São Paulo, Instituto Oceanográfico, São Paulo, 206p.

Milstein D., Medeiros A.S., Oliveira E.C. \& Oliveira M.C. 2012. Will a DNA barcoding approach be useful to identify Porphyra species (Bangiales, Rhodophyta)? Journal of Applied Phycology 24: 837-845.

Milstein D., Medeiros A.S., Oliveira E.C. \& Oliveira M.C. 2015. Native or introduced? A rerevaluation of Pyropia species ((Bangiales, Rhodophyta) from Brazil based on molecular analyses. European Journal of Phycology 50: 37-45.

Miranda, P.T.C. \& Pereira, S.M.B. 1989. Macroalgas bentônicas no manguezal do rio Ceará (Ceará-Brasil). II - Distribuição em função das condições hidrológicas. Arqivos de Ciências do Mar. 28:39-52.

Montagne, J.F.C. 1842. Algae. In: Histoire physique, politique et naturelle de l'lle de Cuba. Botanique-plantes cellulaires. (De La Sagra, R. Eds), pp. 1-104. Paris. 
Moura, C.W.N. 2016a. Cladophoropsis in Lista de Espécies da Flora do Brasil. Jardim Botânico do Rio de Janeiro. Disponível em: <http://floradobrasil.jbrj.gov.br/jabot/floradobrasil/FB99162>. Acesso em: 07 Jan. 2016.

Moura, C.W.N. 2016b. Rhizoclonium in Lista de Espécies da Flora do Brasil. Jardim Botânico do Rio de Janeiro. Disponível em: <http://floradobrasil.jbrj.gov.br/jabot/floradobrasil/FB123944>. Acesso em: 08 Jan. 2016.

Muangmai, N., West, J.A. \& Zuccarello, G.C. 2014. Evolution of four Southern Hemisphere Bostrychia (Rhodomelaceae, Rhodophyta) species: phylogeny, species delimitation and divergence times. Phycologia 53: 593-601.

Muangmai, N., Fraser. C.I. \& Zuccarello, G.C. 2015. Contrasting patterns of population structure and demographic history in cryptic species of Bostrychia intricata (Rhodomelaceae, Rhodophyta) from New Zealand. Journal of Phycology 51:574-585.

Möbius, M. 1889. Bearbeitung der von H. Schenck in Brasilien gesammelten Algen. Hedwigia 28: $309-347$

Nauer, F., Guimarães, N.R., Cassano, V., Yokoya, N.S. \& Oliveira, M.C. 2014. Hypnea species (Gigartinales, Rhodophyta) from the southeastern coast of Brazil based on molecular studies complemented with morphological analyses, including descriptions of Hypnea edeniana sp. nov. and H. flava sp. nov. European Journal of Phycology 49: 550-575.

Nauer, F., Cassano, V. \& Oliveira, M.C. 2015. Description of Hypnea pseudomusciformis sp. nov., a new species based on molecular and morphological analyses, in the context of the H. musciformis complex (Gigartinales, Rhodophyta). Journal of Applied Phycology 27: 2405-2417.

O' Kelly, C.J., Wysor, B. \& Bellows, W.K. 2004. Gene sequence diversity and the phylogenetic position of algae assigned to the genera Phaeophila and Ochlochaete (Ulvophyceae, Chlorophyta). Journal of Phycology 40: 789-799.

Oliveira, M.C. 2001. Estudios de la macro y microbiodiversidad de las algas. Sequenciamiento del DNA ribossomal (rDNA). In: Alveal, K. \& ANtezana, T. (Eds.). Sustentabilidad de la biodiversidad, Universidad de Concepción-Chile, p. 85-96.

Oliveira Filho, E. C. 1977. Algas marinhas bentônicas do Brasil. Universidade de São Paulo, São Paulo, Tese de Livre Docência em Ficologia, 407p.

Oliveira-Carvalho, M.F., Oliveira, M.C., Pereira, S.M.B. \& Verbruggen, H. 2012. Phylogenetic analysis of Codium species from Brazil, with the description of the new species $C$. pernambucensis (Bryopsidales, Chlorophyta). European Journal of Phycology 47: 355365.

Oliveira-Carvalho, M. F. \& Pereira, S .M. B. Catenella in Lista de Espécies da Flora do Brasil. Jardim Botânico do Rio de Janeiro. Disponível em: <http://floradobrasil.jbrj.gov.br/jabot/floradobrasil/FB99897>. Acesso em: 06 Jan. 2016.

Paiano, M.O. \& Necchi Jr. O. 2013. Phylogeography of the freshwater red alga Sirodotia (Batrachospermales, Rhodophyta) in Brazil. Phycological Research 61: 249-255.

Paula, E.J., Ugadim, Y. \& Kanagawa, A.I. 1989. Macroalgas de Manguezais da llha de Maracá, Estado do Amapá, Brasil. Ínsula 19, supl.: 95-114. 
Pedroche, F. F., West, J. A., Zuccarello, G. C., Senties, A. G. \& Karsten, U. 1995. Marine red algae of the mangroves in south Pacific Mexico and Pacific Guatemala. Botanica Marina 38:111-119.

Peña, E.J., Zingmark, R. \& Nietch, C. 1999. Comparative photosynthesis of two species of intertidal epiphytic macroalgae on mangrove roots during submersion and emersion. Journal of Phycology 35:1206-1214.

Posada, D. \& Crandall, K.A. 1998 MODELTEST: testing the model of DNA substitution. Bioinformatics 14: $817-818$.

Post, E. 1936. Systematische und pflanzengeographische Notizen zur Bostrychia-CaloglossaAssoziation. Revue Algologie 9: 1-84.

Post, E. 1939. Weitere Daten zur Verbreitung des Bostrychietum III. Archiv für Protistenkunde 93: 6-37.

Presting. G. G. 2006. Identification of conserved regions in the plastid genome: implications for DNA barcoding and biological function. Canadian Journal of Botany 84: 1434-1443.

Rindi, F., Mclvor, L., Sherwood, A.R., Friedl, T., Guiry, M.D. \& Sheath, R.G. 2007. Molecular phylogeny of the green algal order Prasiolales (Trebouxiophyceae, Chlorophyta). Journal of Phycology 43: 811-822.

Rocha-Jorge, R. 2015. Diversidade de macroalgas nas Unidades de Conservação Insulares do estado de São Paulo, Brasil. Tese de Doutorado, Instituto de Botânica, São Paulo, $222 \mathrm{p}$.

Rodriguez, C. \& Stoner, A.W. 1990. The epiphyte community of mangrove roots in a tropical estuary: distribution and biomass. Aquatic Botany 36:117-126.

Ronquist, F. \& Huelsenbeck, J.P. 2003 MrBayes 3: Bayesian phylogenetic inference under mixed models. Bioinformatics 19: 1572- 1574.

Santos, E. 1965. Características climáticas. Baixada Santista: aspectos geográficos. In: Departamento de Geografia da Faculdade de Filosofia e Letras da Universidade de São Paulo. V. 1.

Saunders, G.W. 2005. Applying DNA barcoding to red macroalgae: a preliminary appraisal holds promise for future applications. Philosophical Transactions of the Royal Society B: Biological Sciences 360:1879-1888.

Saunders, G.W. \& Kucera, H. 2010. An evaluation of rbcL, tufA, UPA, LSU and ITS as DNA barcode markers for the marine green macroalgae. Cryptogamie, Algologie 31: 487-528.

Saunders, G.W. \& Millar, K.R. 2014. A DNA barcode survey of the red algal genus Mazzaella in British Columbia reveals overlooked diversity and new distributional records: descriptions of $M$. dewreedei sp. nov. and M. macrocarpa sp. nov. Botany 92: 223-231.

Schaeffer-Novelli, Y. 1995. Manguezal: Ecossistema entre a terra e o mar. $1^{\circ}$ ed., Caribbean Ecological Research, São Paulo.

Schaeffer-Novelli, Y. \& Cintrón, G. 1986. Guia para estudo de áreas de manguezal: Estrutura, função e flora. $1^{\circ}$ ed., Caribbean Ecological Research. 
Sena, F.S. 2012. Distribuição vertical das macroalgas aderidas em pneumatóforos no manguezal da llha Barnabé (Baixada Santista), SP, Brasil. Monografia final de curso, Universidade Paulista, São Paulo.

Sena, F.S, Menghini, R.P., Cassano, V. \& Sebastiani, R. 2012. Macroalgal community of pneumatophores in a mangrove of Barnabé Island (Baixada Santista), SP, Brazil: preliminary analysis. Communications in Plant Sciences 2: 149-151.

Sherwood, A.A. \& Sheath, R.G. 2003. Systematics of the Hildenbrantiales (Rhodophyta): gene sequence onf morphometric analyses of global collections. Journal of Phycology 39: 409422.

Sherwood, A.R., Kurihara, A., Conklin, K.Y., Sauvage, T. \& Presting, G.G. 2010. The Hawaiian Rhodophyta Biodiversity Survey (2006-2010): a summary of principal findings. BMC Plant Biology 10: 258.

Sherwood, A.R. \& Presting, G.G. 2007. Universal primers amplify a 23s rDNA plastid marker in eukaryotic algae and cyanobacteria. Journal of Phycology 43:605-608.

Sherwood, A.R., Vis, M.L., Entwisle, T.J., Necchi Jr, O. \& Presting, G.G. 2008. Contrasting intra versus interspecies DNA sequence variation for representatives of the Batrachospermales (Rhodophyta): Insights from a DNA barcoding approach. Phycological Research 56:269-279.

Sogin M.L. 1990. Amplification of ribosomal RNA genes for molecular evolution studies. In: PCR protocols. A guide to methods and applications (Ed. by M.A. Innes, D.H. Gelfand, J.J. Snisnky \& T.J. White), Academic Press, San Diego, CA. pp. 307-314.

Stam, W.T., Olsen, J.L., Zaleski, S.F., Murray, S.N., Brown, K.R. \& Walters, L.J. 2006. A forensic and phylogenetic survey of Caulerpa species (Caulerpales, Chlorophyta) from the Florida coast, local aquarium shops, and e-commerce: establishing a proactive baseline for early detection. Journal of Phycology 42: 1113-1124.

Stoeckle, M. 2003. Taxonomy, DNA, and the bar code of life. BioScience 53: 796-797.

Sutherland, J.E., Lindstrom, S.C., Nelson, W.A., Brodie, J., Lynch, M.D., Hwang, M.S., Choi, H.-G., Miyata, M., Kikuchi, N., Oliveira, M.C., Farr, T., Neefus, C., Mols-Mortensen, A. Milstein, D. \& Müller, K.M. 2011. A new look at an ancient order: generic revision of the Bangiales (Rhodophyta). Journal of Phycology 47: 1131-1151.

Swofford, D. L. 2000. PAUP*. Phylogenetic Analysis Using Parsimony ("and Other Methods).Version 4. Sinauer Associates, SunderlandTaylor, W.R. 1931. A synopsis of the marine algae of Brasil. Revue Algologique 5: 1-35.

Taylor, W.R., Joly, A.B. \& Bernatowicz, A.J. 1953. The relation of Dichotomosiphon pusillus to the algal genus Boodleopsis. Papers of the Michigan Academy of Sciences, Arts and Letters 38: 97-107, Plates I-III.

Taylor, W.R. 1960. Marine algae of the eastern tropical and subtropical coasts of the Americas. Ann Arbor: The University of Michigan Press. xi +870 p.

Ugadim, Y. 1976. Ceramiales (Rhodophyta) do litoral sul do estado de São Paulo e do litoral do estado do Paraná (Brasil). Boletim de Botânica, Universidade de São Paulo 4: 133172.

Verbruggen, H., Tyberghein, L., Paul, Y. K., Vlaeminck C., van Nieuwenhuyze, K., Koositra, W. H. C. F., Leliaert, F. \& De Clerck O. 2009a. Macroecology meets macroevolution: 
evolutionary niche dynamics in the seaweed Halimeda. Global Ecology and Biogeography 18: 393-405.

Verbruggen, H., Ashworth, M., LoDuca, S.T., Vlaeminck, C., Cocquyt, E., Sauvage, T.,

Zechman, F. W., Littler, D.S., Littler, M.M., Leliaert, F. \& De Clerck, O. 2009b. A multi-locus time-calibrated phylogeny of the siphonous green algae. Molecular Phylogenetics and Evolution 50: 642-653.

Ximenes, C.F. 2015 Taxonomia e Filogenia dos representantes do gênero Halimeda Lamour. (Bryopsidales, Chlorophyta) no Brasil. Dissertação de Mestrado. Universidade Federal Rural de Pernambuco. 81p.

West, J.A. \& Calumpong. H.P. 1988. Dawsoniocolax bostrychiae (Choreocolacaceae, Gigartinales), an alloparasitic red alga new to Australia. Phycologia 27: 463-468.

West, J.A., Zuccarello, G.C., Pedroche, F.F. \& Karsten, U. 1994. Caloglossa apomeiotica sp. nov. (Ceramiales, Rhodophyta) from Pacific México. Botanica Marina 37: 381-390.

Yang, M.Y. \& Kim, M.S. 2014. Taxonomy of Grateloupia (Halymeniales, Rhodophyta) by DNA barcode marker analysis and a description of Pachymeniopsis volvita sp. nov. Journal of Applied Phycology 27: 1373-1384.

Yokoya, N. S. et al. 1999. Temporal and spatial variations in the structure of macroalgal communities associated with mangrove trees of Ilha do Cardoso, São Paulo state, Brazil. Revista Brasileira de Botânica. 22: 195-204

Yoneshigue-Braga, Y. 1970. Flora marinha bentônica da Baía de Guanabara e cercanias. I. Chlorophyta. Publicações do Instituto de Pesquisa da Marinha, Rio de Janeiro 42: 1-55.

Yoneshigue-Valentin, Y. \& Amado-Filho, G.M. 1989. Ocorrência de Cladophoropsis macromeres (Siphonocladales, Chlorophyta) na região sudeste do Brasil (Estado do Rio de Janeiro). Ensaios de cultivo. Ínsula 19: 83-94.

Zuccarello, G. C. \& West, J. A. 1994. Host specificity on the red algal parasites Bostrychiocolax australis and Dawsoniocolax bostrychiae (Choreocolacaceae, Rhodophyta). Journal of Phycology 30: 462-473.

Zuccarello, G. C. and West, J. A. 1995. Hybridization studies in Bostrychia: 1. B. radicans (Rhodomelaceae, Rhodophyta) from Pacific and Atlantic North America. Phycological Research 43: 233-40.

Zuccarello, G. C. \& West, J. A. 1997. Hybridization studies in Bostrychia: 2. correlation of crossing data and plastid DNA sequence data within $B$. radicans and $B$. moritziana (Ceramiales, Rhodophyta). Phycologia 36: 293-304.

Zuccarello, G.C. \& West, J.A. 2002. Phylogeography of the Bostrychia calliptera/B. pinnata complex (Rhodomelaceae, Rhodophyta) and divergence rates based on nuclear, mitochondrial and plastid DNA markers. Phycologia 41: 49-60.

Zuccarello, G.C. \& West, J. A. 2003. Multiple cryptic species: molecular diversity and reproductive isolation in the Bostrychia radicans/ $B$. moritziana complex (Rhodomelaceae, Rhodophyta) with focus on North American isolates. Journal of Phycology 39:948-959. 
Zuccarello, G.C. \& West, J.A. 2006. Molecular phylogeny of the subfamily Bostrychioideae (Ceramiales, Rhodophyta): subsuming Stictosiphonia and highlighting polyphyly in species of Bostrychia. Phycologia 45: 24-36.

Zuccarello, G.C. \& West, J.A. 2008. Bostrychia (Rhodomelaceae, Rhodophyta) species of New Zealand, and relationships in the Southern Hemisphere. New Zealand Journal of Marine and freshwater Research 42: 315-324.

Zuccarello, G.C. \& West, J.A. 2011. Insight into evolution and speciation in the red alga Bostrychia: 15 years of research. Algae 26: 21-32.

Zuccarello, G.C., Burger, G., West, J.A. \& King, R.J. 1999a. A mitochondrial marker for red algal intraspecific relationships. Molecular Ecology 8: 1443-1447.

Zuccarello, G. C., West, J. A. \& King, R. J. 1999b. Evolutionary divergence in the Bostrychia moritziana/B. radicans complex (Rhodomelaceae, Rhodophyta): molecular and hybridization data. Phycologia 38: 234-244.

Zuccarello, G.C., Buchanan, J. \& West, J.A. 2006. Increased sampling for inferring phylogeographic patterns in Bostrychia radicans/Bostrychia moritziana in the eastern USA. Journal of Phycology 42: 1349-1352.

Zuccarello, G.C., Buchanan, J. \& West, J.A. \& Pedroche, F. 2011. Genetic diversity of the mangrove-associated alga Bostrychia radicans/Bostrychia moritziana (Ceramiales, Rhodophyta) from southern Central America. Phycological Research 59: 98-104.

Zuccarello, G., Kamiya, M., Ootsuki, R., Göer, S.L., Pedroche, F.F. \& West, J.A. 2012. New records of red algae from mangroves in El Salvador and Pacific Mexico, combining culture and molecular observations. Botanica Marina 55: 101-111.

Zuccarello, G.C., Moon, D. \& Goff, L.J. 2004. Phylogenetic study of parasitic genera placed in the family Choreocolacaceae (Rhodophyta). Journal of Phycology 40: 937-945.

Zuccarello, G., Price, N., Verbruggen, H. \& Leliaert, F. 2009. Analysis of a plastid multigene data set and the phylogenetic position of the marine macroalga Caulerpa filiformis (Chlorophyta). Journal of phycology 45: 1206-1212. 


\section{APÊNDICE A - Tabela de amostras sequenciadas}

Tabela 7 - Amostras sequenciadas neste estudo.

\begin{tabular}{|c|c|c|c|c|c|c|c|c|}
\hline Amostra & Coletor & $\begin{array}{c}\text { Data da } \\
\text { Coleta }\end{array}$ & Local de coleta & $\begin{array}{c}\text { COI- } \\
5 \mathrm{P} \\
\end{array}$ & UPA & $r b c L$ & SSU & ITS \\
\hline \multicolumn{9}{|c|}{ Bostrychia Montagne } \\
\hline $\mathrm{C} 115^{\star \star *}$ & $\begin{array}{l}\text { F.Sena, } \\
\text { R.P.Menghini }\end{array}$ & 24/02/2015 & Ilha Barnabé, Santos, SP - área 1 & & * & & & \\
\hline C116*** & $\begin{array}{l}\text { F.Sena, } \\
\text { R.P.Menghini }\end{array}$ & 24/02/2015 & Ilha Barnabé, Santos, SP - área 1 & & * & & & \\
\hline IB001 & $\begin{array}{l}\text { F.Sena, } \\
\text { R.P.Menghini }\end{array}$ & 24/02/2013 & Ilha Barnabé, Santos, SP - área 1 & * & * & * & & \\
\hline IB002 & $\begin{array}{l}\text { F.Sena, } \\
\text { R.P.Menghini }\end{array}$ & $24 / 02 / 2013$ & Ilha Barnabé, Santos, SP - área 1 & * & * & & & \\
\hline IB003 & $\begin{array}{l}\text { F.Sena, } \\
\text { R.P.Menghini }\end{array}$ & $24 / 02 / 2013$ & Ilha Barnabé, Santos, SP - área 1 & & * & & & \\
\hline IB004 & $\begin{array}{l}\text { F.Sena, } \\
\text { R.P.Menghini }\end{array}$ & 24/02/2013 & Ilha Barnabé, Santos, SP - área 1 & * & * & & & \\
\hline IB007 & $\begin{array}{l}\text { F.Sena, } \\
\text { R.P.Menghini }\end{array}$ & 24/02/2013 & Ilha Barnabé, Santos, SP - área 1 & * & * & & & \\
\hline IB008 & $\begin{array}{l}\text { F.Sena, } \\
\text { R.P.Menghini }\end{array}$ & 24/02/2013 & Ilha Barnabé, Santos, SP - área 1 & * & * & * & & \\
\hline IB009 & $\begin{array}{l}\text { F.Sena, } \\
\text { R.P.Menghini }\end{array}$ & 24/02/2013 & Ilha Barnabé, Santos, SP - área 1 & & * & & & \\
\hline IB011 & $\begin{array}{l}\text { F.Sena, } \\
\text { R.P.Menghini }\end{array}$ & 24/02/2013 & Ilha Barnabé, Santos, SP - área 1 & & * & & & \\
\hline IB117 & $\begin{array}{l}\text { F.Sena, } \\
\text { R.P.Menghini }\end{array}$ & 08/09/2013 & Ilha Barnabé, Santos, SP - área 1 & & * & * & & \\
\hline IB012 & $\begin{array}{l}\text { F.Sena, } \\
\text { R.P.Menghini }\end{array}$ & 24/02/2013 & Ilha Barnabé, Santos, SP - área 1 & & * & & & \\
\hline IB013 & $\begin{array}{l}\text { F.Sena, } \\
\text { R.P.Menghini }\end{array}$ & $24 / 02 / 2013$ & Ilha Barnabé, Santos, SP - área 1 & & * & & & \\
\hline IB014 & $\begin{array}{l}\text { F.Sena, } \\
\text { R.P.Menghini }\end{array}$ & 24/02/2013 & Ilha Barnabé, Santos, SP - área 1 & & * & & & \\
\hline IB015 & $\begin{array}{l}\text { F.Sena, } \\
\text { R.P.Menghini }\end{array}$ & 24/02/2013 & Ilha Barnabé, Santos, SP - área 1 & & * & & & \\
\hline IB016 & $\begin{array}{l}\text { F.Sena, } \\
\text { R.P.Menghini }\end{array}$ & 24/02/2013 & Ilha Barnabé, Santos, SP - área 1 & & * & & & \\
\hline IB023 & $\begin{array}{l}\text { F.Sena, } \\
\text { R.P.Menghini }\end{array}$ & 24/02/2013 & Ilha Barnabé, Santos, SP - área 1 & & * & & & \\
\hline IB024 & $\begin{array}{l}\text { F.Sena, } \\
\text { R.P.Menghini }\end{array}$ & 24/02/2013 & Ilha Barnabé, Santos, SP - área 1 & * & * & & & \\
\hline IB028 & $\begin{array}{l}\text { F.Sena, } \\
\text { R.P.Menghini }\end{array}$ & 24/02/2013 & Ilha Barnabé, Santos, SP - área 1 & & * & & & \\
\hline IB029 & $\begin{array}{l}\text { F.Sena, } \\
\text { R.P.Menghini }\end{array}$ & $24 / 02 / 2013$ & Ilha Barnabé, Santos, SP - área 1 & & * & & & \\
\hline IB030 & $\begin{array}{l}\text { F.Sena, } \\
\text { R.P.Menghini }\end{array}$ & 24/02/2013 & Ilha Barnabé, Santos, SP - área 1 & & * & & & \\
\hline IB042 & $\begin{array}{l}\text { F.Sena, } \\
\text { R.P.Menghini }\end{array}$ & 09/06/2013 & Ilha Barnabé, Santos, SP - área 3 & * & * & * & & \\
\hline IB043 & $\begin{array}{l}\text { F.Sena, } \\
\text { R.P.Menghini }\end{array}$ & 09/06/2013 & Ilha Barnabé, Santos, SP - área 3 & * & * & * & & \\
\hline IB045 & $\begin{array}{l}\text { F.Sena, } \\
\text { R.P.Menghini }\end{array}$ & 09/06/2013 & Ilha Barnabé, Santos, SP - área 3 & * & * & & & \\
\hline IB063 & $\begin{array}{l}\text { F.Sena, } \\
\text { R.P.Menghini }\end{array}$ & 09/06/2013 & Ilha Barnabé, Santos, SP - área 3 & * & * & * & & \\
\hline
\end{tabular}


Tabela 6 - Continuação

\begin{tabular}{|c|c|c|c|c|c|c|c|c|}
\hline Amostra & Coletor & $\begin{array}{l}\text { Data da } \\
\text { Coleta }\end{array}$ & Local de coleta & $\begin{array}{l}\mathrm{COI}- \\
5 \mathrm{P}\end{array}$ & UPA & $r b c L$ & SSU & ITS \\
\hline IB070 & $\begin{array}{l}\text { F.Sena, } \\
\text { R.P.Menghini }\end{array}$ & $09 / 06 / 2013$ & Ilha Barnabé, Santos, SP - área 3 & * & * & & & \\
\hline IB072 & $\begin{array}{l}\text { F.Sena, } \\
\text { R.P.Menghini }\end{array}$ & 09/06/2013 & Ilha Barnabé, Santos, SP - área 3 & * & * & * & & \\
\hline IB083 & $\begin{array}{l}\text { F.Sena, } \\
\text { R.P.Menghini }\end{array}$ & 08/09/2013 & Ilha Barnabé, Santos, SP - área 1 & & * & * & & \\
\hline IB095 & $\begin{array}{l}\text { F.Sena, } \\
\text { R.P.Menghini }\end{array}$ & 08/09/2013 & Ilha Barnabé, Santos, SP - área 2 & & * & * & & \\
\hline IB099 & $\begin{array}{l}\text { F.Sena, } \\
\text { R.P.Menghini }\end{array}$ & 08/09/2013 & Ilha Barnabé, Santos, SP - área 2 & * & * & * & & \\
\hline $10 S^{*}$ & Khey Fontes & 21/08/2009 & $\begin{array}{l}\text { Taperoá, BA (13³2'09.83"S; } \\
\text { 3905'31.56"O) }\end{array}$ & * & * & * & & \\
\hline $11 S^{*}$ & Khey Fontes & $21 / 08 / 2009$ & $\begin{array}{l}\text { Galeão, BA (13²4'06.85"S; } \\
\left.39^{\circ} 02^{\prime} 10.850\right)\end{array}$ & * & * & & & \\
\hline $13 S^{*}$ & Khey Fontes & $21 / 08 / 2009$ & $\begin{array}{l}\text { Galeão, BA (13²4'06.85"S; } \\
\left.39^{\circ} 02^{\prime} 10.850\right)\end{array}$ & & * & & & \\
\hline $14 S^{*}$ & Khey Fontes & 21/08/2009 & $\begin{array}{l}\text { Galeão, BA (13²4'06.85"S; } \\
\left.39^{\circ} 02^{\prime} 10.850\right)\end{array}$ & & * & & & \\
\hline $16 S^{*}$ & Khey Fontes & $21 / 08 / 2009$ & $\begin{array}{l}\text { Galeão, BA (13²4'06.85"S; } \\
\left.39^{\circ} 02^{\prime} 10.850\right)\end{array}$ & & * & & & \\
\hline $17 S^{*}$ & Khey Fontes & $04 / 11 / 2009$ & $\begin{array}{l}\text { Florianópolis, SC }\left(27^{\circ} 38^{\prime} 56.97^{\prime S} \text {; }\right. \\
\left.48^{\circ} 31^{\prime 2} 22.70^{\prime O}\right)\end{array}$ & & * & * & & \\
\hline $18 S^{*}$ & Khey Fontes & $04 / 11 / 2009$ & $\begin{array}{l}\text { Florianópolis, SC }\left(27^{\circ} 38^{\prime} 56.97^{\prime \prime} \text {; }\right. \\
\left.48^{\circ} 31^{\prime} 22.70^{\prime O}\right)\end{array}$ & & * & * & & \\
\hline $19 S^{*}$ & Khey Fontes & 04/11/2009 & $\begin{array}{l}\text { Florianópolis, SC }\left(27^{\circ} 38^{\prime} 56.97^{\prime \prime} \text {; }\right. \\
\left.48^{\circ} 31^{\prime} 22.70^{\prime O}\right)\end{array}$ & & * & * & & \\
\hline $1 S^{*}$ & Khey Fontes & $13 / 04 / 2009$ & $\begin{array}{l}\text { Bragança, PA (0॰50'42.08"S; } \\
\left.46^{\circ} 38^{\prime} 51.08^{\prime \prime O}\right)\end{array}$ & * & * & & & \\
\hline $20 S^{*}$ & Khey Fontes & 04/11/2009 & $\begin{array}{l}\text { Florianópolis, SC }\left(27^{\circ} 38^{\prime} 56.97^{\prime S} \text {; }\right. \\
\left.48^{\circ} 31^{\prime} 22.70^{\prime O}\right)\end{array}$ & & * & & & \\
\hline $21 S^{*}$ & Khey Fontes & $04 / 11 / 2009$ & $\begin{array}{l}\text { Florianópolis, SC }\left(27^{\circ} 38^{\prime} 56.97^{\prime S} \text {; }\right. \\
48^{\circ} 31^{\prime 22.70 " O) ~}\end{array}$ & * & * & & & \\
\hline $22 S^{*}$ & Natália Guimarães & 01/06/2010 & $\begin{array}{l}\text { Ilha do Cardoso, SP (250.'20.9"S; } \\
\left.47^{\circ} 54^{\prime} 55.9^{\prime \prime O}\right)\end{array}$ & & * & * & & \\
\hline $24 S^{*}$ & Cícero Silva & 08/09/2010 & $\begin{array}{l}\text { Parna Açu, São Luís, MA } \\
\left(2^{\circ} 35^{\prime} 35.00^{\prime S} \text {; } 44^{\circ} 24^{\prime} 13.00^{\prime \prime O}\right)\end{array}$ & * & * & * & & \\
\hline $2 S^{*}$ & Khey Fontes & $14 / 04 / 2009$ & $\begin{array}{l}\text { Bragança, PA (0॰50'42.08"S; } \\
\left.46^{\circ} 38^{\prime} 51.08^{\prime \prime O}\right)\end{array}$ & & * & & & \\
\hline $31 S^{*}$ & Khey Fontes & 21/08/2009 & $\begin{array}{l}\text { Galeão, BA (13²4'06.85"S; } \\
\left.39^{\circ} 02^{\prime} 10.850\right)\end{array}$ & & & * & & \\
\hline $5 S^{*}$ & Khey Fontes & 26/05/2009 & $\begin{array}{l}\text { Vila Velha, Itamaracá, PE } \\
\text { (7048'41.32"S; 3451'25.83"O) }\end{array}$ & & * & & & \\
\hline $6 S^{*}$ & Khey Fontes & $26 / 05 / 2009$ & $\begin{array}{l}\text { Vila Velha, Itamaracá, PE } \\
\text { (7048'41.32"S; 3451'25.83"O) }\end{array}$ & & * & & & \\
\hline $7 S^{*}$ & Khey Fontes & $26 / 05 / 2009$ & $\begin{array}{l}\text { Vila Velha, Itamaracá, PE } \\
\left(7^{\circ} 48^{\prime} 41.32^{\prime \prime} \text {; } 34^{\circ} 51^{\prime 25.83 " O)}\right.\end{array}$ & * & * & * & & \\
\hline $8 S^{*}$ & Khey Fontes & 21/08/2009 & $\begin{array}{l}\text { Galeão, BA (13²4'06.85"S; } \\
\left.39^{\circ} 02^{\prime} 10.850\right)\end{array}$ & * & * & & & \\
\hline $9 S^{*}$ & Khey Fontes & 21/08/2009 & $\begin{array}{l}\text { Galeão, BA (1324'06.85"S; } \\
\left.39^{\circ} 02^{\prime} 10.850\right)\end{array}$ & * & * & & & \\
\hline
\end{tabular}


Tabela 6 - Continuação

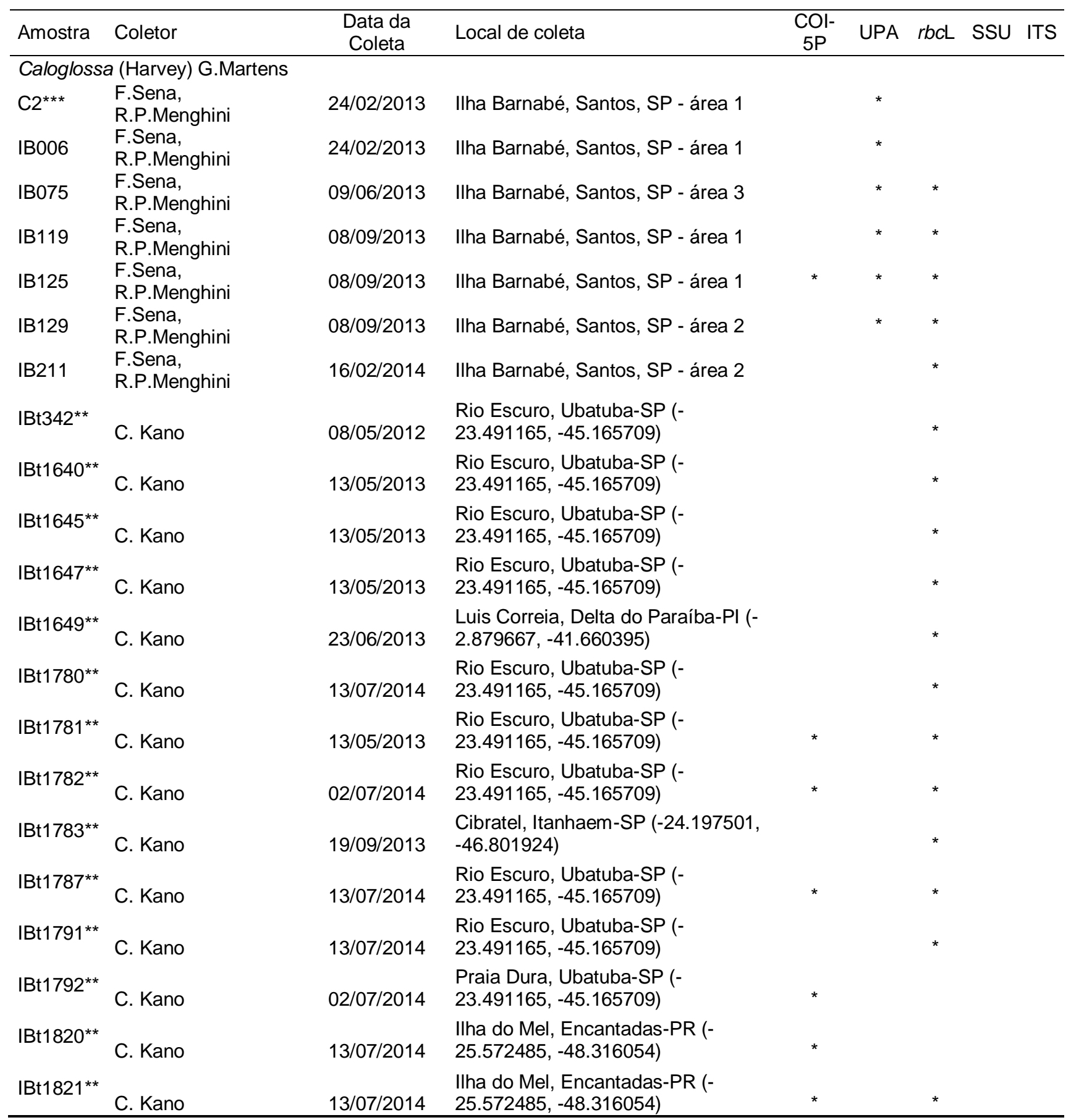


Tabela 6 - Continuação

\begin{tabular}{|c|c|c|c|c|c|c|c|c|}
\hline Amostra & Coletor & $\begin{array}{c}\text { Data da } \\
\text { Coleta }\end{array}$ & Local de coleta & $\begin{array}{c}\text { COI- } \\
5 \mathrm{P}\end{array}$ & UPA & $r b c L$ & SSU & ITS \\
\hline \multicolumn{9}{|c|}{ Catenella Greville } \\
\hline IB003 & $\begin{array}{l}\text { F.Sena, } \\
\text { R.P.Menghini }\end{array}$ & $24 / 02 / 2013$ & Ilha Barnabé, Santos, SP - área 1 & & * & & & \\
\hline IB005 & $\begin{array}{l}\text { F.Sena, } \\
\text { R.P.Menghini }\end{array}$ & $24 / 02 / 2013$ & Ilha Barnabé, Santos, SP - área 1 & & * & & * & \\
\hline IB010 & $\begin{array}{l}\text { F.Sena, } \\
\text { R.P.Menghini }\end{array}$ & $24 / 02 / 2013$ & Ilha Barnabé, Santos, SP - área 1 & & * & & * & \\
\hline IB118 & $\begin{array}{l}\text { F.Sena, } \\
\text { R.P.Menghini }\end{array}$ & 08/09/2013 & Ilha Barnabé, Santos, SP - área 1 & & * & & * & \\
\hline \multicolumn{9}{|c|}{ Boodleopsis Gepp \& E.S. Gepp } \\
\hline IB088 & $\begin{array}{l}\text { F.Sena, } \\
\text { R.P.Menghini }\end{array}$ & 08/09/2013 & Ilha Barnabé, Santos, SP - área 2 & & & * & & \\
\hline IB123 & $\begin{array}{l}\text { F.Sena, } \\
\text { R.P.Menghini }\end{array}$ & 08/09/2013 & Ilha Barnabé, Santos, SP - área 2 & & & * & & \\
\hline \multicolumn{9}{|c|}{ Cladophoropsis Børgesen } \\
\hline IB096 & $\begin{array}{l}\text { F.Sena, } \\
\text { R.P.Menghini }\end{array}$ & 08/09/2013 & Ilha Barnabé, Santos, SP - área 1 & & & & & * \\
\hline IB100 & $\begin{array}{l}\text { F.Sena, } \\
\text { R.P.Menghini }\end{array}$ & 08/09/2013 & Ilha Barnabé, Santos, SP - área 1 & & & & & * \\
\hline
\end{tabular}

* Amostras gentilmente cedidas por K.A. Fontes

${ }^{* *}$ Amostras gentilmente cedidas por C.H. Kano

${ }^{* * *}$ Amostras do cultivo 